\title{
DIGITAL-SIMULATION AND PROJECTION OF HEAD CHANGES IN THE POTOMAC-RARITAN-MAGOTHY AQUIFER SYSTEM, COASTAL PLAIN, NEW JERSEY
}

\author{
U.S. GEOLOGICAL SURVEY
}

Water-Resources Investigations 80-11

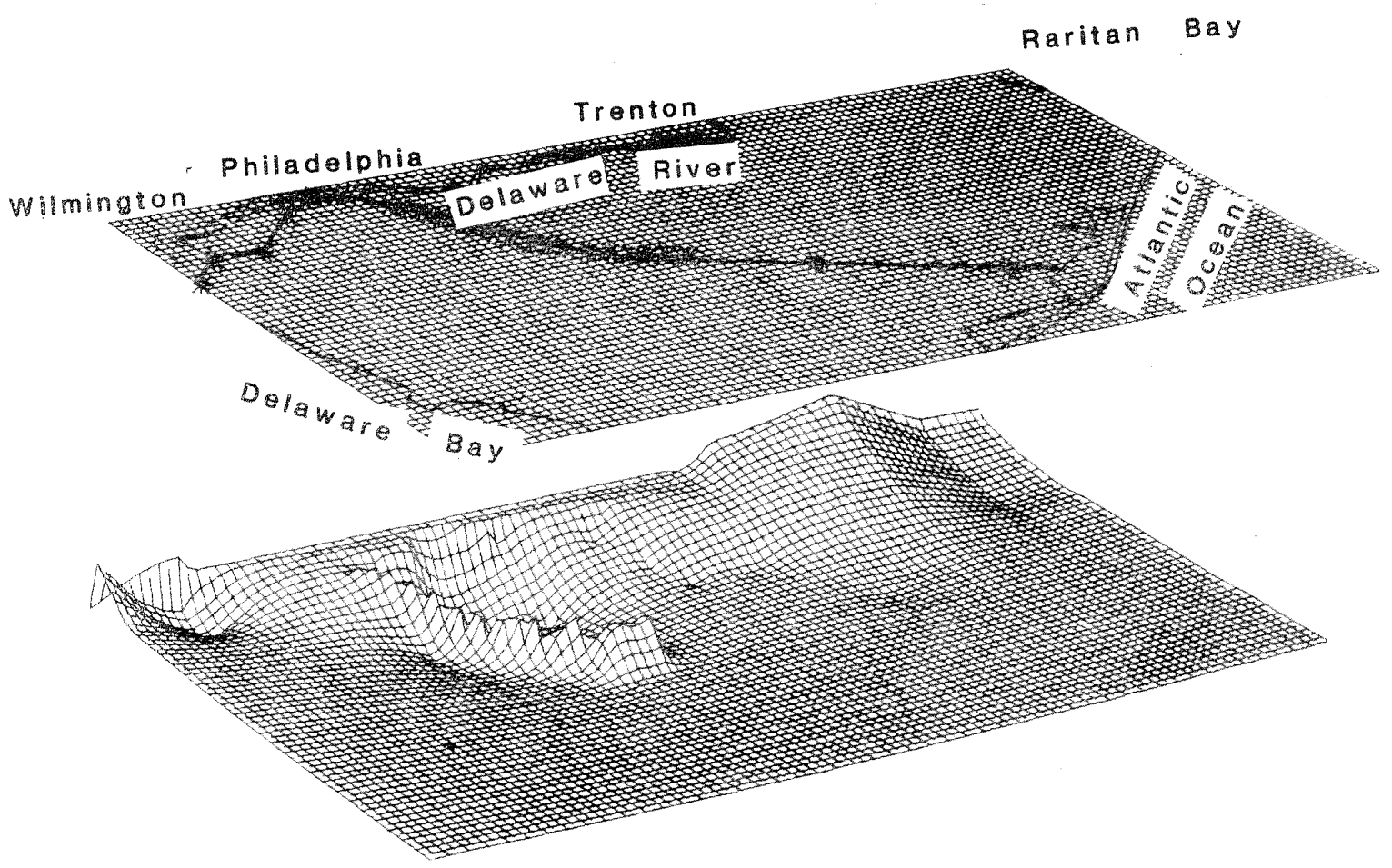

Prepared in cooperation with the New Jersey

Department of Environmental Protection, Division of Water Resources

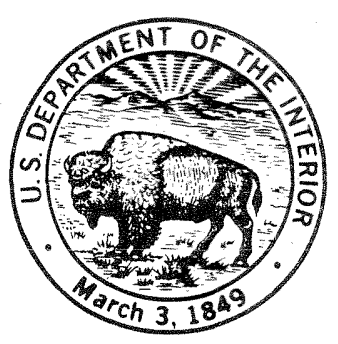


4. Title and Subtitle Digital-simulation and projection of head changes in the Potomac-Raritan-Magothy aquifer system, Coastal Plain, New Jersey

7. Author(s)

James E. Luzier

5. Report Date

June 1980

6.

8. Performing Organization Rept. No. USGS / WRI / NTIS / 80-11

9. Performing Organization Name and Address

U.S. Geological Survey

Water Resources Division

402 East State Street

Trenton, New Jersey 08607

12. Sponsoring Organization Name and Address

U.S. Geological Survey

Water Resources Division

402 East State Street

Trenton, New Jersey 08607

15. Supplementary Notes

Prepared in cooperation with the New Jersey Department of Environmental Protection,

Division of Water Resources

16. Abstract (Limit: 200 words) A digital model was used to simulate the response of the Potomac-

Raritan-Magothy aquifer system to pumping stresses during the 18-year period, 1956-73.

The model was used to compute projected potentiometric heads and trends to the year 2000. Three sets of conditions were simulated: (1) no increase in ground-water extractions; (2) continued growth in ground-water extractions at the rate of 3 percent annually; and (3) continued growth in ground-water extractions at the rate of 3 percent annually, in conjunction with the activation of a freshwater head barrier in the freshsalty water transition zone.

Under the first set of conditions, further head reduction would cease over very large regions within two years. Under the second set of conditions, the broad cone of depression would broaden and deepen. Heads would range from 60 to 160 feet below NGVD of 1929 with declines after 1973 approaching 90 feet in some areas. The resultant steeper hydraulic gradients would accelerate the movement of salty ground water toward the pumping centers. If a freshwater head barrier were constructed across a 35 -mile stretch in Gloucester, Camden, and Burlington Counties, the total rates of injection needed would range from about 56 cubic feet per second in year 1984 to about 95 cubic feet per second in year 2000. Barrier recharge rates would be equivalent to about 20 percent of the ground water pumped.

27. Document Analysis a. Descriptors

*Computer mode1s, *simulation analyses, aquifers,

saquicludes, ground water, hydrologic properties,

*leakage

b. Ldentifiers/Open-Ended Terms

Potomac Group, Raritan Formation, Magothy Formation, New Jersey, Coastal Plain

c. COSATI Field/Group

18. Availability Statement

No restriction on distribution.

\begin{tabular}{|l|l|}
\hline $\begin{array}{l}\text { 19. Security Class (This Report) } \\
\text { Unclassified }\end{array}$ & $\begin{array}{c}\text { 21. No. of Pages } \\
80\end{array}$ \\
\hline $\begin{array}{c}\text { 20. Security Class (This Page) } \\
\text { Unclassified }\end{array}$ & 22. Price \\
\hline
\end{tabular}




\section{DIGITAL-SIMULATION AND PROJECTION OF HEAD CHANGES IN THE POTOMAC-RARITAN-MAGOTHY AQUIFER SYSTEM, COASTAL PLAIN, NEW JERSEY}

By J.E. Luzier

U.S. GEOLOGICAL SURVEY

Water-Resources Investigations 80-11

Prepared in cooperation with the New Jersey

Department of Environmental Protection, Division of Water Resources

May 1980

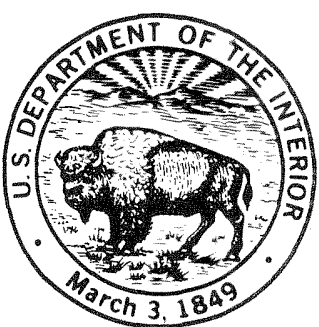




\section{UNITED STATES DEPARTMENT OF THE INTERIOR \\ CECIL D. ANDRUS, Secretary \\ GEOLOGICAL SURVEY \\ H. W. Menard, Director}

For additional information write to:

U.S. Geological Survey

436 Federal Building

P.O. Box 1238

Trenton, New Jersey 08607 


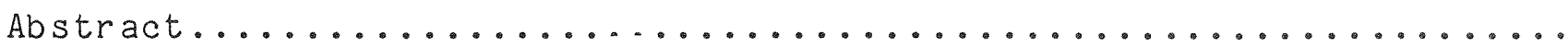

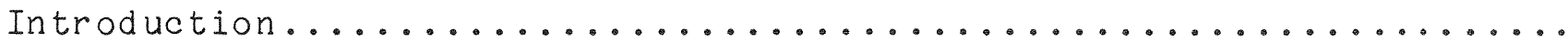

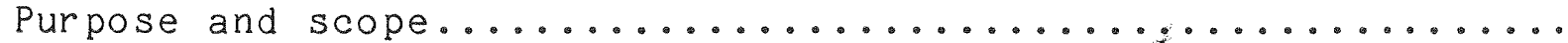

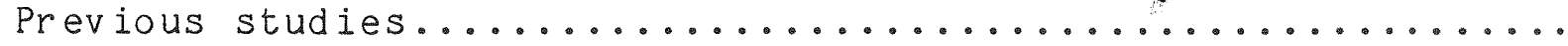

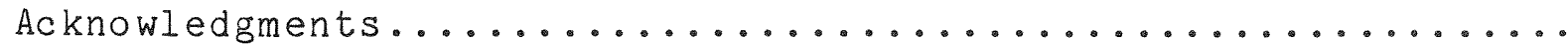

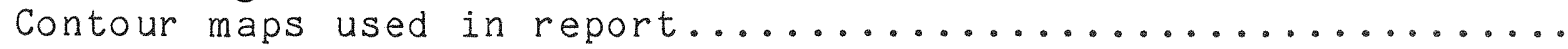

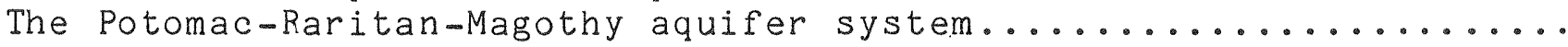

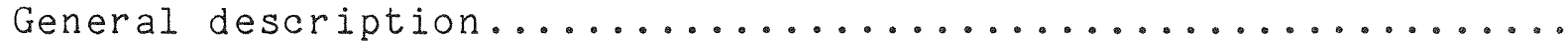

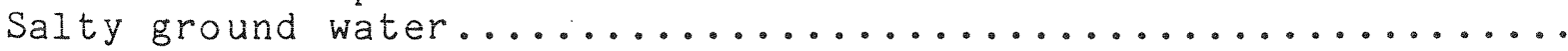

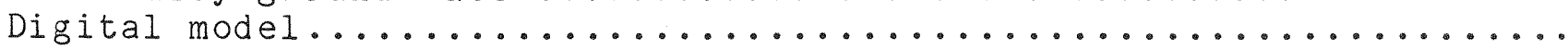

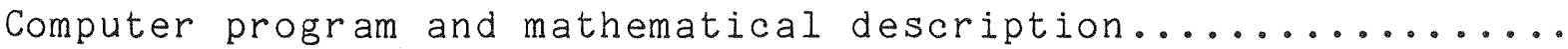

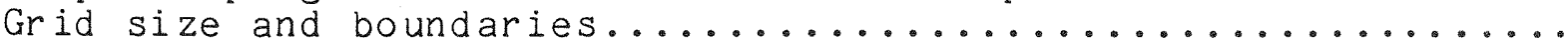

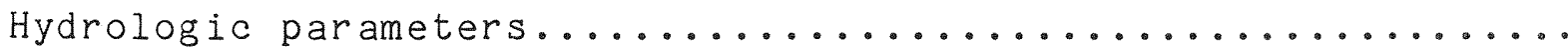

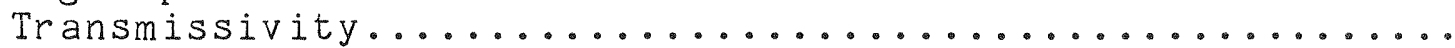

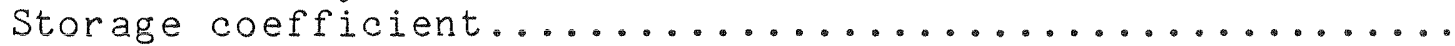

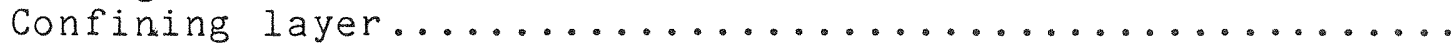

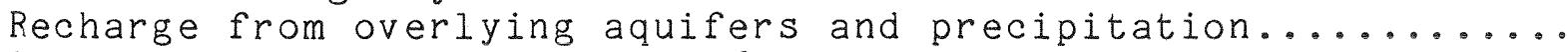

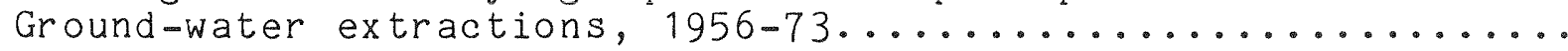

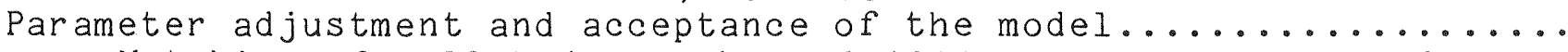

Matching of well hydrographs and 1973 potentiometric surface...

Comparison of steady-state solution to prepumping conditions

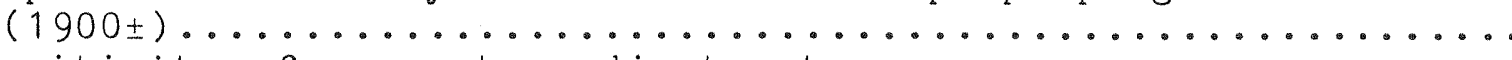

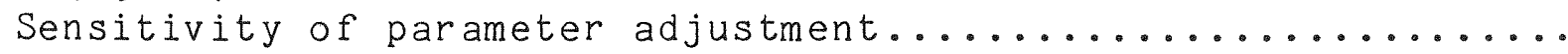

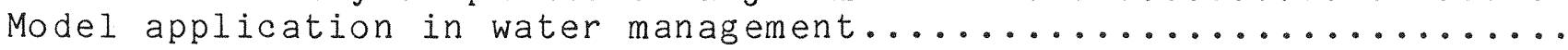

Projected changes in potentiometric surface, 1974-2000,

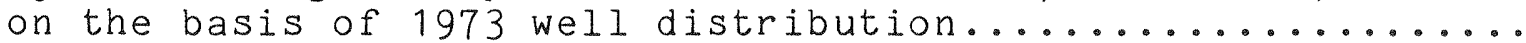

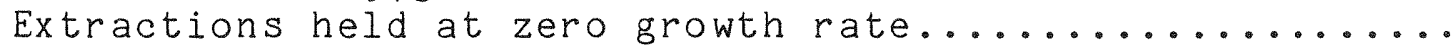

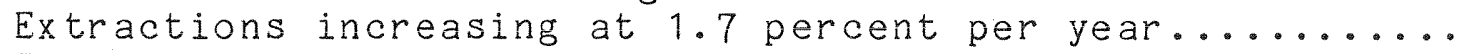

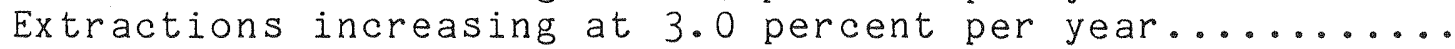

Estimating amount of artificial recharge required to

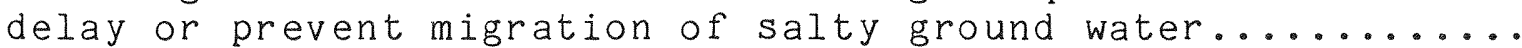

Ground-water velocities near fresh to salty water transition zone...

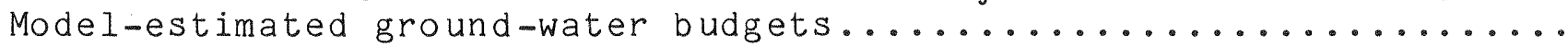

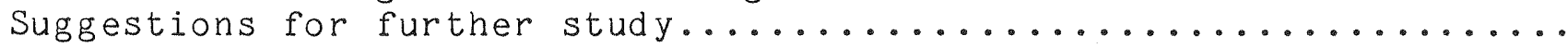

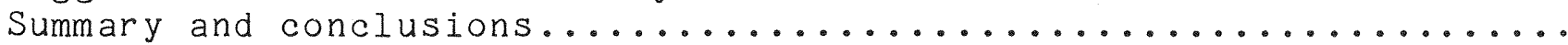

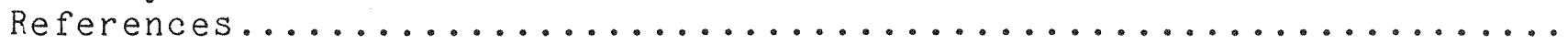

\section{ILLUSTRATIONS}

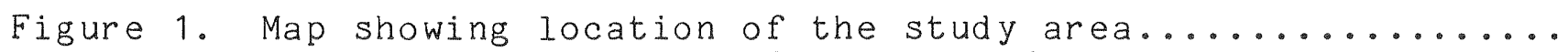
2. Map showing altitude of the top of the Potomac-

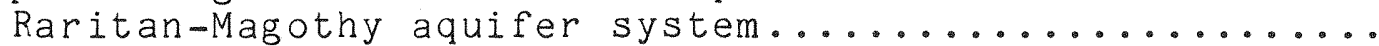

3. Map showing altitude of the bottom of the Potomac-

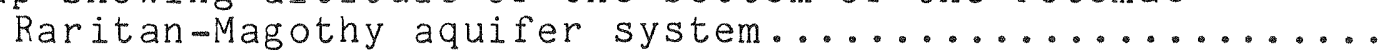

4. Cross section showing approximate distribution of

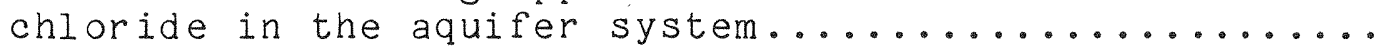

5. Summarized flow chart of the computer program and the

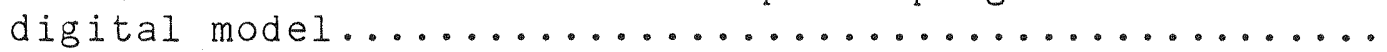

6. Map showing finite difference grid and boundaries used

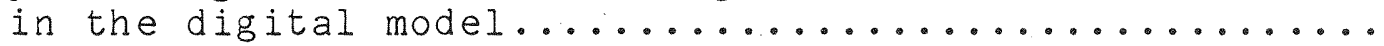


7. Map showing distribution of transmissivity used in the model for the Potomac-Raritan-Magothy aquifer system.

8. Map showing thickness of the Merchantville Formation-

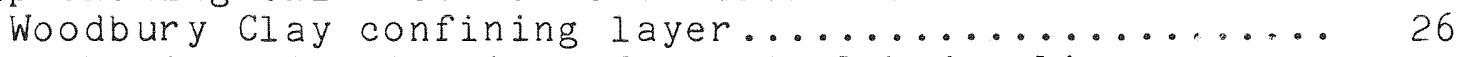

9. Map showing distribution of vertical hydraulic conductivity of the Merchantville Formation-woodbury

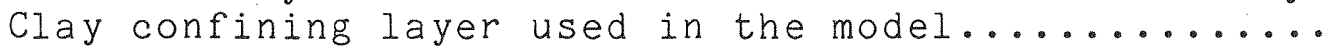

10. Map showing the composite potentiometric surface of the Englishtown and Wenonah-Mount Laurel

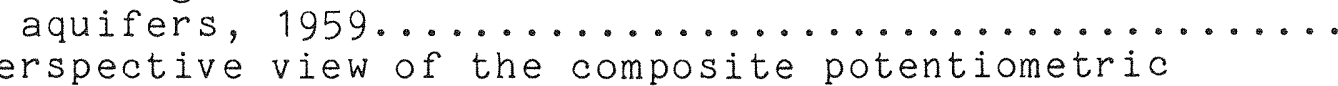

11. Perspective view of the composite potentiometric
surface (1959) over the confining layer and the computed steady-state (1900t) potentiometric surface of the Potomac-Raritan-Magothy aquifer system........

12. Perspective view of the distribution of ground-water extractions from the Potomac-Raritan-Magothy

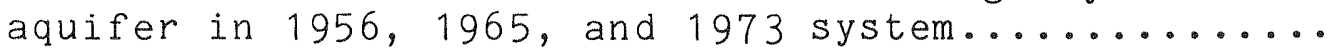

13. Map showing potentiometric surface of the PotomacRaritan-Magothy aquifer system, $1956 \ldots \ldots \ldots \ldots \ldots$

14. Map showing potentiometric surface of the PotomacRaritan-Magothy aquifer system,

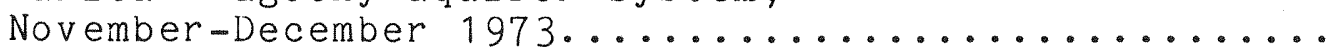

15. Perspective view of the potentiometric surfaces of the Potomac-Raritan-Magothy aquifer system observed in 1956 and 1973 , respectively .............
ap showing potentiometric surface of the Potomac-

16. Map showing potentiometric surface of the Potomac
Raritan-Magotry aquifer system, December 1973,

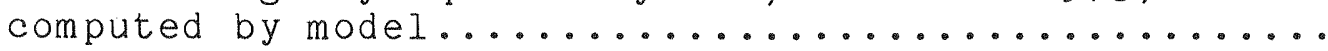

17. Observed and computed hydrographs of welis paraliel to or located within the outcrop area along the northwestern side of the cone of depression.........

18. Observed and computed hydrographs of wells located in the northwestern part of the cone of depression.....

19. Observed and computed hydrographs of wells located in the southern part of the cone of depression.........

20. Map showing comparison of model-produced steady-state

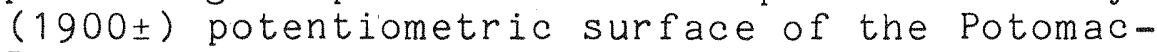
Raritan-Magothy aquifer system and that of Barksdale

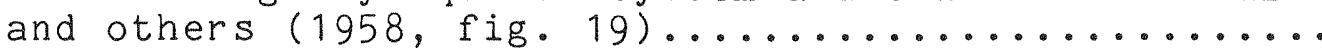

21. Map showing the theoretical flow pattern and location of the interface between freshwater and salty water in the Potomac-Raritan-Magothy aquifer system

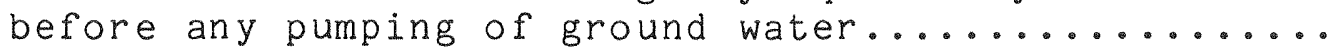

22. Graph showing effect of model-wide changes in

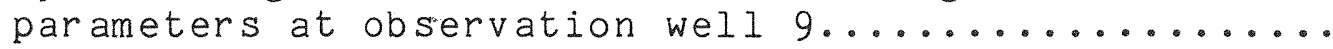

23. Graph showing actual and projected ground-water
extractions from the Potomac-Raritan-Magothy aquifer

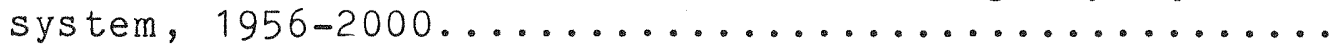

24. Observed and projected hydrograph trends of wells 1 ,

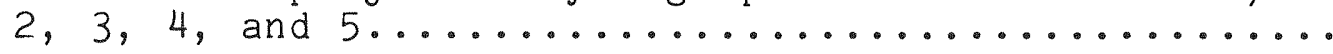


Page

25. Observed and projected hydrograph trends of wells 6 ,

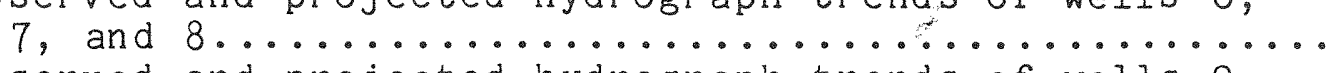
53

26. Observed and projected hydrograph trends of wells 9

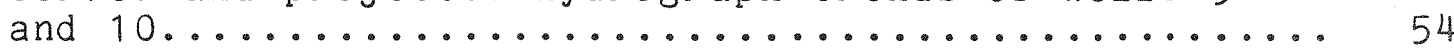

27. Map showing potentiometric surface of the PotomacRaritan-Magothy aquifer system at year 2000 computed by model with annual extraction growth

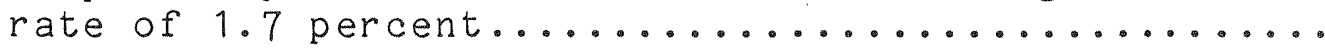

28. Perspective potentiometric surfaces of the PotomacRaritan-Magothy aquifer system observed in 1973 and projected to year 2000 using annual extraction

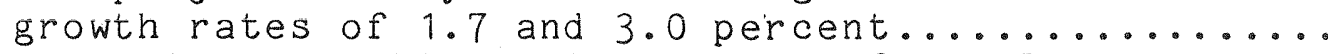

29. Map showing potentiometric surface of the PotomacRaritan-Magothy aquifer system computed by model with annual extraction growth rate of 3.0 percent....

30. Map showing potentiometric surface of the PotomacRaritan-Magothy aquifer system in year 2000 computed by model with freshwater head barrier activated in 1984 and maintained at an altitude

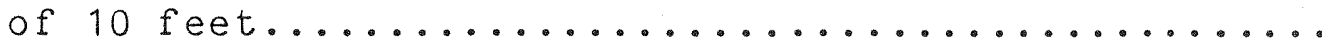

31. Perspective potentiometric surfaces of the PotomacRaritan-Magothy aquifer system computed by model at various time periods after activation of

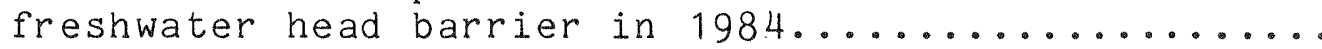

32. Computed ground-water budget rates in the fine-grid

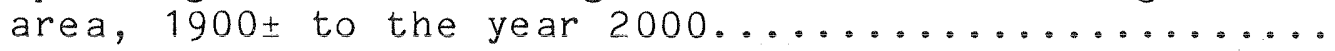

TABLES

Table 1. Vertical variation in heads and chlorides at

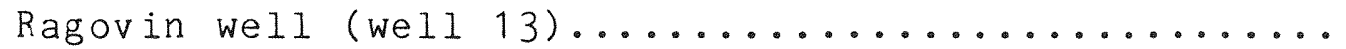

2. Time step sequencing used in the digital model,

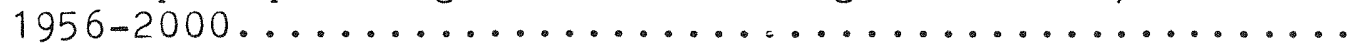

3. Laboratory determined vertical hydraulic conductivities of the Merchantville Formation and Woodbury Clay

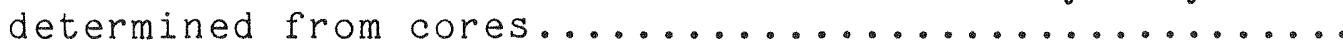

4. Annual extraction rates, $1956-73 \ldots \ldots \ldots \ldots \ldots \ldots \ldots \ldots . \ldots \ldots$

5. Estimated average ground-water velocities near the

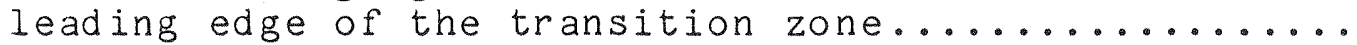

6. Computed ground-water budget net flux rates in cubic feet per second within the fine-grid area for various

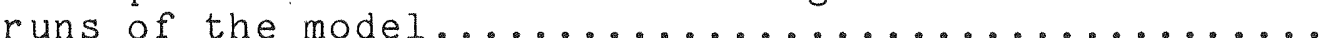


FACTORS FOR CONVERTING INCH-POUND UNITS TO

INTERNATIONAL SYSTEM UNITS (SI)

Inch-pound units of measure have been used in this report

and may be converted to SI (International System of Units, a modernized metric system of measurement) by use of the following table:

Multiply inch-pound units

$\underline{B y}$

To obtain SI units

feet $(f t)$

0.3048

meters $(\mathrm{m})$

square feet $\left(f t^{2}\right)$

0.0929

square meters $\left(\mathrm{m}^{2}\right)$

cubic feet per second

0.02832

cubic meters per second $\left(\mathrm{m}^{3} / \mathrm{s}\right)$

gallons (gal)

3.7854

liters (L)

gallons per minute (gal/min)

0.06309

liters per second ( $\mathrm{L} / \mathrm{S}$ )

inches (in)

2.54

centimeters $(\mathrm{cm})$

pound-force per square inch

$\left(\right.$ lbf/in $\left.{ }^{2}\right)$

6.895

kilopascals

$(\mathrm{kPa})$ 
The Potomac-Raritan-Magothy aquifer system of Cretaceous age, which is the principal source of water to the major population and industrial centers in the Coastal Plain of New Jersey, has undergone continuous and widespread reduction in head. The reduced head, already below sea level throughout most of the aquifer system, in conjunction with encroachment of salty water toward centers of pumping, threatens the continued use of the aquifer as a source of freshwater in the area.

A single layer, two-dimensional finite difference digital model was used to simulate the response of the aquifer system to pumping stresses during the 18-year period, 1956-73. Model simulations were based on close agreement between (1) observed and calculated heads and head trends for 10 observation wells during the period, 1956-73; and (2) the computed nonpumping steady-state potentiometric surface and a potentiometric surface based on early water-level observations $(1900 \pm)$. In addition, the hydrologic budget estimated by the model appears to be reasonable for the transient (1956-73) and the steady-state (1900I) solutions.

The model was used to compute projected potentiometric heads and trends to the year 2000. Three sets of conditions, all using the 1973 distribution'of pumping centers, were sinulated. The conditions are:

(1) no increase in ground-water extractions;

(2) continued growth in ground-water extractions at the rate of 1.7 and 3 percent annually and;

(3) continued growth in ground-water extractions at the rate of 3 percent annually, in conjunction with the activitation of a freshwater head barrier in the fresh-salty water transition zone.

Under the first set of conditions, further head reduction would cease over very large regions within two years. Under the second set of conditions involving a 3 percent growth rate similar to that experienced during the sinulation period, the broad cone of depression already encompassing most of the New Jersey Coastal Plain would broaden and deepen. Heads would range from 60 to 160 feet below National Geodetic Vertical Datum of 1929. The reduction of head after 1973 would approach 90 feet in some areas. The resultant steeper hydraulic gradients would accelerate the rate of movement of salty ground water toward the pumping centers. A freshwater head barrier could be established in the transition zone to prevent migration of salty ground water across a 35-mile stretch in Gloucester, Camden, and Burlington Counties. A line of injection wells 
would be required, with total rates of injection to the head barrier ranging from about 56 cubic feet per second in 1984 to about 95 cubic feet per second in 2000 . Barrier recharge rates would be equivalent to about 20 percent of the ground water pumped in the fine-grid area in any particular year for a 3 percent increase in extractions.

\section{INTRODUCTION}

\section{Purpose and Scope}

Ground-water extractions from the Potomac-Raritan-Magothy aquifer system in the New Jersey Coastal Plain have almost doubled in the last 18 years, 1956-73, causing a continuous and widespread decline in water levels. Growth of industry and population along the Delaware River and Raritan Bay since 1900 was responsible for the initial deinand for ground water. However, in recent years, much of the additional ground-water demand has been shifting gradually away from these areas toward the more lightly populated areas of the coastal plain. This shift has generally moved additional pumping centers away from the outcrop of the aquifer system, resulting in placement of many pumping centers in proximity to a large body of salty ground water that presently occupies the aquifer system throughout much of the southern half of the coastal plain.

The more recently developed pumping centers tap downdip parts of the aquifer system remote from important recharge areas along the Delaware River and adjacent outcrop. Consequently, the wells are strongly artesian and, when they are pumped, widespread pressure reductions occur throughout much of. the aquifer system. Broad cones of depression with potentiometric heads well below sea level have already encompassed most of the aquifer system, including that portion containing the salty ground water. Decrease of head in the aquifer system slowly causes updip migration of the salty ground water; thus, the fresh ground water is threatened with contamination. Similarly, induced recharge from the salty (250 to 3,000 $\mathrm{mg} / \mathrm{L}$ chloride), lower reach of the Delaware River southwest of Philadelphia and Camden is moving downdip in response to aquifer heads that are decreased below sea level. All of these factors are critical to the future availability and development of ground water in the region.

The U.S. Geological Survey, in cooperation with the Division of Water Resources of the New Jersey Department of Environmental Protection, is conducting a program of geohydrologic studies of aquifer systems in the New Jersey Coastal Plain. These studies utilize digital computer simulations. The area of this study lies mainly within the Coastal Plain of New Jersey but extends slightly into the nearby states (fig. 1). The study was started in 1972 . In 1976, the U.S. Army Corps of Engineers furnished additional financial support for the investigation because of their interest in using the model to explore several water-management alternatives. 


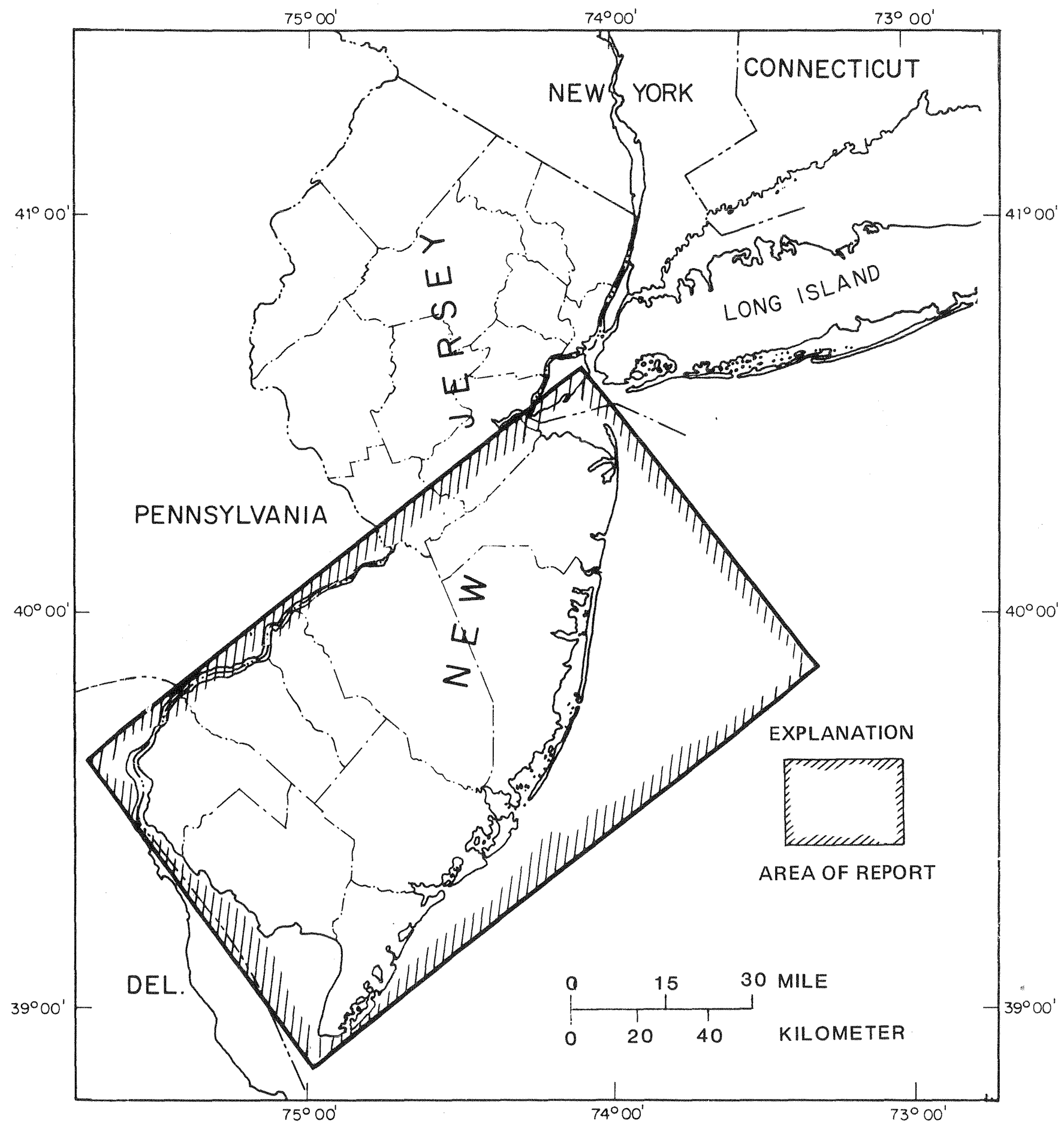

Figure 1.--Location of the study area. 
The digital model constructed for this study is designed for use in predicting head distribution within the aquifer system (primarily in Burlington, Camden, Gloucester and Salem Counties) in response to pumping or injecting freshwater. Future pumping sites and pumping rates may be specified, with or without a redistribution or discontinuance of any of those wells already in existence. The sites and rates may be varied with time. Examples are illustrated in the report.

\section{Previous Studies}

Numerous studies of coastal-plain geology and ground-water resources have been made in New Jersey, and the adjacent states of Pennsylvania, Delaware, and New York since about 1900. Most of the reports were restricted to a limited area, such as a county. County studies included those of Anderson and Appel (1969), Barksdale and others (1943), Hardt and Hilton (1969), Jablonski (1968), Sundstrom and Pickett (1971), Rosenau and others (1969), Rush (1968), Vecchioli and Palmer (1962), and Farlekas and others (1976). Regional appraisals include those of Parker and others (1964), Gill and Farlekas (1976), Nemickas (1976), and Barksdale and others (1958). The latter study by Barksdale and others includes the most complete and perceptive study of the PotomacRaritan-Magothy aquifer system published to date, and has been widely referenced during this study.

\section{Acknowledgments}

This study was greatly facilitated by the cooperation of many well owners who made their wells available for measurement in November and December 1973. All well owners generously provided records or estimates of ground-water extraction when requested. The assistance provided by well drilling firms in allowing access to newly completed wells for geophysical logging and furnishing of well records is greatly appreciated.

Prof. George F. Pinder, Roger Pare, and William G. Price of Princeton University provided assistance in setting up the plotting program used to produce the three-dimensional perspective views and contour maps presented in this report.

\section{Contour Maps Used in Report}

All contour maps presented in the report have been produced from data input files used in the simulation model, or from data output files such as head maps, generated by the model. In preparing data input files, hand drawn contour maps are interpolated to obtain values for the variable sized elements throughout the model. These values were then coded, keypunched, and placed in magnetic storage. The values were then linearly reinterpolated by a computer program to an equal size grid ( $\left.1 \mathrm{mi}^{2}\right)$ and machine contoured or drawn in perspective using the PURVUE plotting program written by Price (1976). The interpolation 
procedures, particularly in large elements of the model grid outside the principal area of interest (the fine-grid area), may lead to sone loss of detail in comparison to the original maps. Therefore, contour maps credited to other workers should be considered as modified versions of the original.

\section{THE POTOMAC-RARITAN-MAGOTHY AQUIEER SYSTEM \\ General Description}

The Potomac Group, along with the overlying Raritan and Magothy Formations, make up the regionally extensive PotomacRaritan-Magothy aquifer system. The aquifer system consists of wedge-shaped interbedded sand, silt, and clay and underlies the entire Coastal Plain of New Jersey and parts of adjacent states and extends seaward probably at least $100 \mathrm{mi}$ to the continental slope. The aquifer system is exposed in a narrow outcrop along the Fall Line and the Delaware River. Between the outcrop area near Camden and the coastline near Atlantic City, the top surface ( $\mathrm{fig} .2$ ) of the aquifer system dips at about $40 \mathrm{ft} / \mathrm{mi}$; whereas, the bedrock surface at the bottom of the aquifer system (fig. 3) dips at about $90 \mathrm{ft} / \mathrm{mi}$. At Atlantic City, the top and bottom of the wedge-shaped aquifer system lie at about a depth of $2,500 \mathrm{ft}$ and 5,000 ft, respectively, below NGVD of 1929. According to data presented by Schlee and others (1976, p. 927-940), sediments of approximately equivalent age (Early to Late cretaceous) thicken seaward to more than 13,000 ft near the axis of the Baltimore Canyon trough about $60 \mathrm{mi}$ off the New Jersey coast.

The aquifer is overlain by the Merchantville-Woodbury confining layer consisting of the Merchantville Formation and the Woodbury Clay. The Woodbury Clay retains a tough, dense character wherever encountered and is probably the least permeable confining layer in the Coastal Plain of New Jersey (Barksdale and others, 1958, p. 136). These units form an effective but leaky separation between the studied aquifer and overlying aquifers such as the Englishtown aquifer and the Wenonah-Mount Laurel aquifer.

According to Perry and others (1975, p. 1529-1535), the oldest and thickest part of the aquifer system is in the Lower Cretaceous part of the Potomac Group. This unit, in New Jersey, is a nonmarine deltaic sequence of sand, silt, and silty clay. Marine sand associated with the deltaic sequence may be present seaward under the Outer Continental Shelf.

On the basis of glauconite and various fossils, the overlying sand and clay of the Raritan Formation of Late Cretaceous age are considered chiefly of marine origin along coastal New Jersey except in the Raritan Bay area where they may be chiefly nonmarine (Perry and others, 1975, p. 1535). In the Delaware Valley area, the Raritan is chiefly nonmarine. 


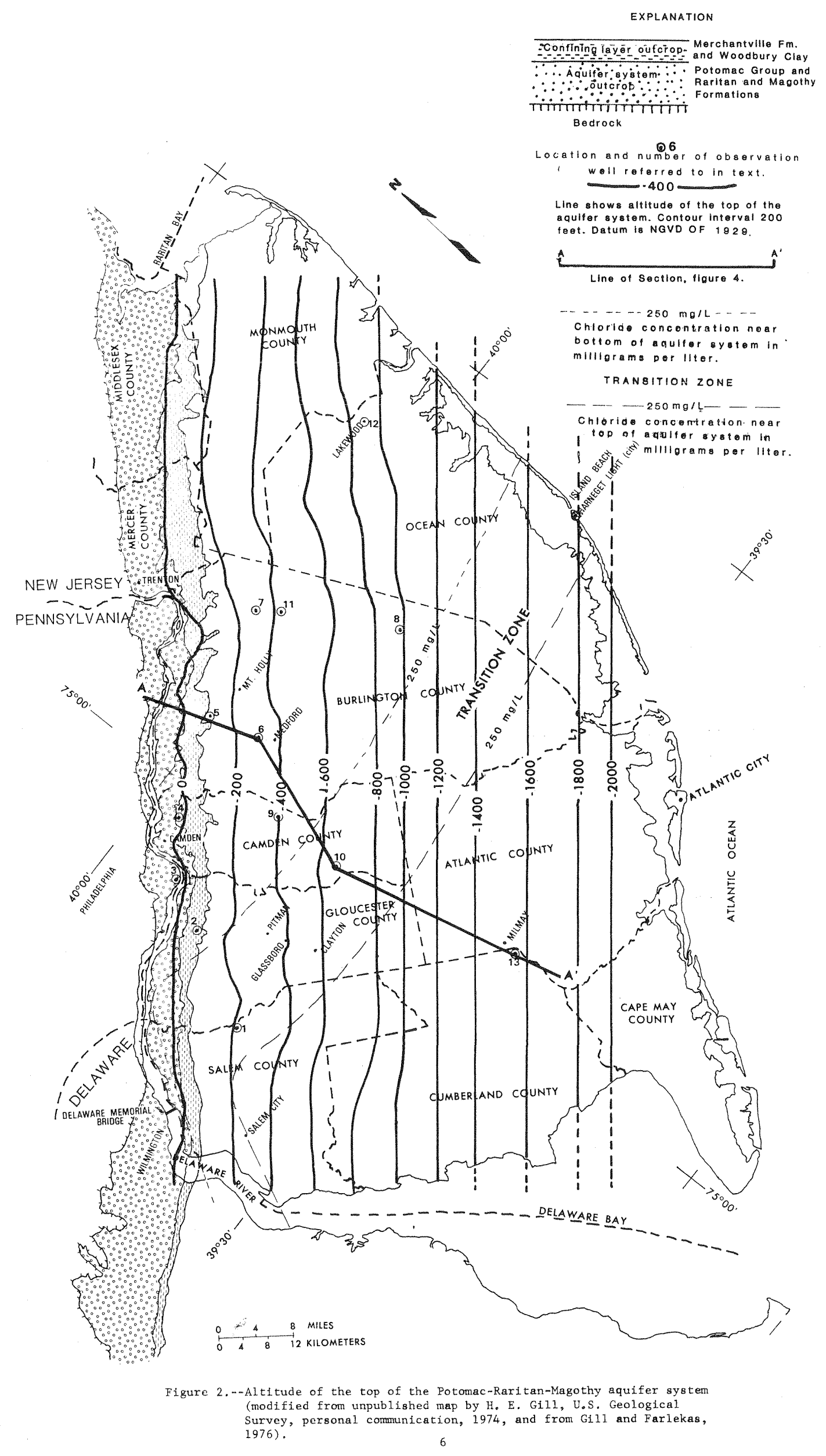




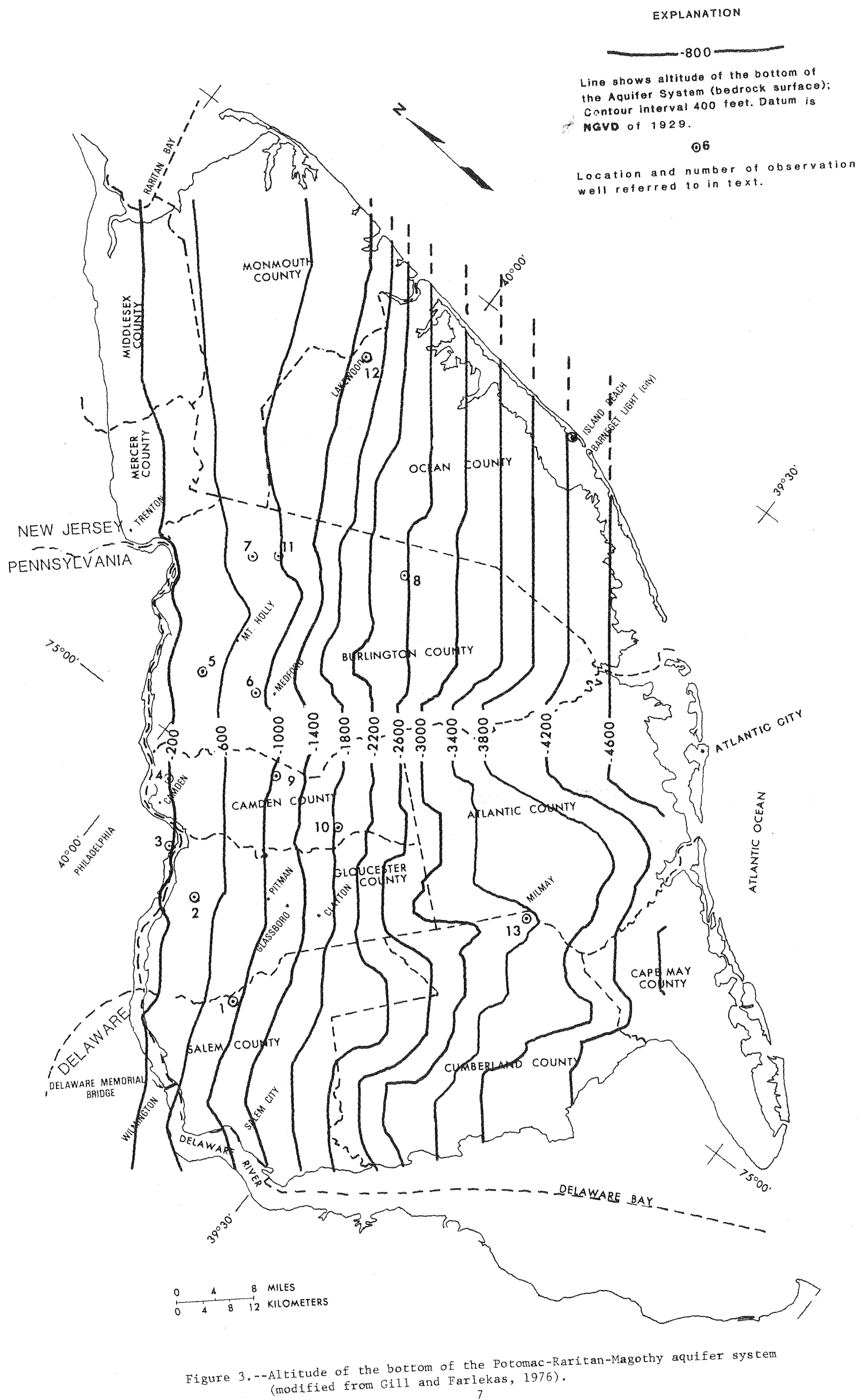


The Magothy Formation, which consists chiefly of coarse beach sand and associated marine and lagoonal clay and silt, unconformably overlies the Raritan Formation and is of Late cretaceous age. This formation thins southward along coastal New Jersey; whereas, the Raritan shows little thinning and the underlying Potomac Group nearly triples in thickness southward. For a more detailed discussion of coastal-plain stratigraphy, the reader is referred to Perry and others, 1975, and Petters, 1976. The reader is also referred to Brown and others (1972) and Schlee and others (1976) for a detailed discussion of the structural and stratigraphic framework.

The Potomac Group and the Raritan and Magothy Formations appear to function together as a hydrologic system. Barksdale and others (1958, p. 91) believe that the major aquifers within this system are hydraulically connected with each other at some distance, if not locally. Individual aquifers and intervening clay beds appear to lack continuity. However, the aquifers are somewhat more continuous than the clay beds. Long-term records at clustered observation wells and records at individual observation wells, some of which are quite remote from pumping centers, demonstrate that much of the aquifer system in New Jersey responds uniformly to pumping stress. Most notably, potentiometric heads throughout most of the confined portion of the aquifer system have been declining at rates of about 1.5 to $2.5 \mathrm{ft} / \mathrm{yr}$ in recent years $(1966-75)$.

Well 6 near Medford (fig. 3) is one of a cluster of three wells; each screened at different levels near the top, middle, and bottom (330, 670, and 1,043 ft below mean sea level, respectively) of the studied hydrologic unit. Despite numerous intervening clay beds between each screened interval, rates of head decline have been nearly identical in each interval for the period of record. In addition, the average head difference is only about $3 \mathrm{ft}$. The two deeper zones have nearly identical heads, which are about $3 \mathrm{ft}$ higher than that in the upper zone. Similarly, wells 9 and 10 (Elm Tree and New Brooklyn Park locations) are at sites where each have two wells screened at intervals vertically separated by 400 ft (well 9) and $550 \mathrm{ft}$ (well 10). Rates of head decline are quite similar in all zones, although head differences between the upper and deeper zones are about 7 to $10 \mathrm{ft}$ at the Elm Tree site, and about 12 to $17 \mathrm{ft}$ at the New Brooklyn Park site. At each site, the deepest zone has the head of highest altitude. Such head differences with depth are to be expected in the aquifer system and probably are a result of pumping stress.

The widespread extent of head reduction in the aquifer system is illustrated by water-level data given in table 1 observed at the Ragovin well (well 13, fig. 3). Five intervals in this abandoned oil test well were jet perforated, screened, and pump tested in 1974. Although the well is located about $22 \mathrm{mi}$ downdip from the nearest pumping wells (at Clayton) and at least $29 \mathrm{mi}$ from the nearest large pumping center in Camden County, the rate of head decline for the period of 1974-77 was about $1.6 \mathrm{ft} / \mathrm{yr}$ in 
Table 1.--Vertical variation in heads and chlorides at Ragovin well (wel1 13, sig. 2)

\begin{tabular}{|c|c|c|c|}
\hline $\begin{array}{l}\text { Altitude of top } \\
\text { of } 10 \text { foot } \\
\text { perforated and } \\
\text { screened interval }\end{array}$ & $\begin{array}{l}\text { Altitude of } \\
\text { uncorrected } \\
\text { head }\end{array}$ & $\begin{array}{l}\text { Altitude of } \\
\text { freshwater } \\
\text { head } \\
\text { (corrected) } *\end{array}$ & $\begin{array}{l}\text { Chloride } \\
\text { concentration } \\
(\mathrm{mg} / \mathrm{L})\end{array}$ \\
\hline$-1998 *$ & -32.0 & -15.1 & 11,000 \\
\hline-2495 & -51.7 & $-23 \cdot 5$ & 12,000 \\
\hline-3017 & -62.7 & -8.1 & 18,000 \\
\hline-3195 & -73.7 & -9.9 & 22,000 \\
\hline-3318 & -78.4 & 3.6 & 27,000 \\
\hline$-3465 \%$ & $-59 \cdot 3$ & 10.2 & 21,000 \\
\hline
\end{tabular}

* Top of screen in existing observation well (since 1974).

* Top of screen in original observation well; during entire period of record, 1962-74, no measurable amount of pressure reduction occurred although well appeared (from tests) to be open to a thick basal sand.

* Heads corrected for density, temperature, and pressure at time of measurement. 
the upper part of the aquifer system $(-1,998-f t$ zone, table 1$)$. The rate for the same period at the New Brooklyn Park well (well 10, fig. 2), $21 \mathrm{mi}$ updip from well 13 and about $6 \mathrm{mi}$ from any pumping wells, was about $3.0 \mathrm{ft} / \mathrm{yr}$. These data and similar data from other remote observation wells such as the Butler Place well (well 8, fig. 2) and the Island Beach well, located at the coast near Barnegat Light ( $f i g .2$ ) indicate that significant head decline is occurring throughout the aquifer system in coastal New Jersey, and probably for considerable distances offshore.

It should be noted that the basal sand unit at the Ragovin observation well appears to be completely isolated from the rest of the aquifer system. Intervening zones $(-2,495 \mathrm{ft}$ and below, table 1) were backfilled after testing and rates of head change are not known.

\section{Salty Ground Water}

A large part of the aquifer system in the southern Coastal Plain of New Jersey contains salty ground water with chloride concentrations ranging from less than 250 to as high as 27,000 $\mathrm{mg} /$ L. The concentration of chloride increases with depth as well as towards the ocean.

A generalized cross section of the aquifer system (Iine $A-A^{\prime}$ ', fig. 2) from the Delaware River southward across the transition zone to the Ragovin well (well 13, fig. 2) is shown in figure 4. Figure 4 was constructed on the basis of chloride data observed in wells 6, 10, and 13 and the chloride concentration observed at Pitman, Glassboro, and Clayton (about 30, 50, and $120 \mathrm{mg} / \mathrm{L}$ chloride, respectively); together with the assumption that increases of chloride concentration with depth are similar to those reported by Rosenau and others (1969, p. 31) for the Salem City area. Their report states that the chloride concentrations are 444, 700,879, 1,760, and 2,057 mg/L for depths of 263, 350, 550, 709, and $714 \mathrm{ft}$ below land surface. There is no sharp interface between fresh ground water and salty ground water. For practical purposes a transition zone (or diffusion zone) is defined. At one boundary of the transition zone the chloride concentration of the ground water increases with depth and reaches $250 \mathrm{mg} / \mathrm{L}$ at the bottom of the aquifer system. At the other boundary of the transition zone the chloride concentration of the ground water reaches $250 \mathrm{mg} / \mathrm{L}$ at the top of the aquifer system (fig. 4).

Results of hundreds of water analyses throughout the coastal plain suggest that background chloride concentration in the aquifer probably ranges from about 2 to $5 \mathrm{mg} / \mathrm{L}$. Farlekas and others (1976, p. 137) report average chloride concentrations of wells in the confined parts of the aquifer in Camden county (excluding the New Brooklyn Park well) to be $4.1 \mathrm{mg} / \mathrm{L}$, and Rush (1968, p. 36) reports that most wells in Burlington County have chloride concentrations of less than $5 \mathrm{mg} / \mathrm{L}$. Chloride concentrations in excess of 6 to $8 \mathrm{mg} / \mathrm{L}$ are probably a result of 


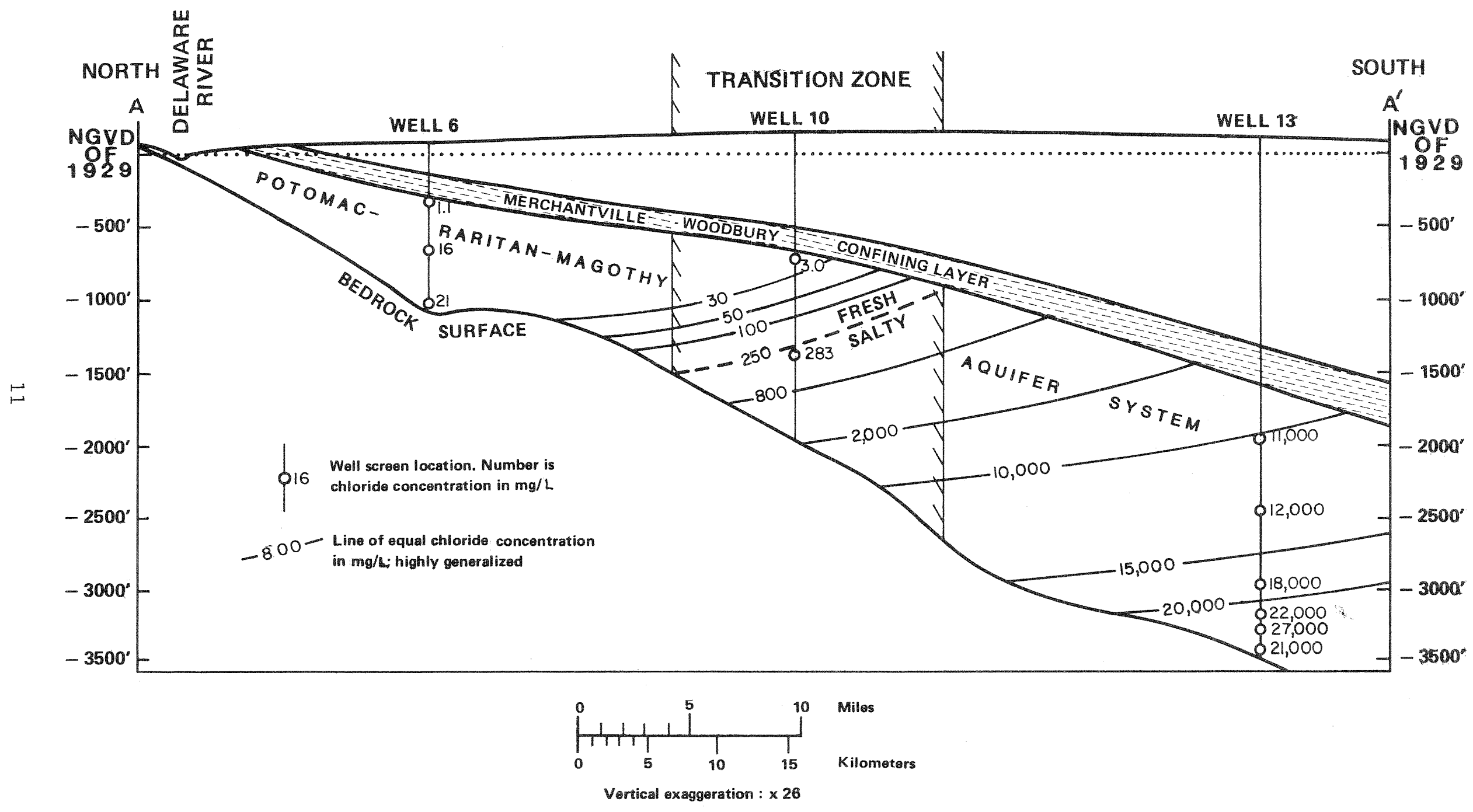

Figure 4.--Cross section showing approximate distribution of chloride in the Potomac-Raritan Vagothy aquifer system (line of section shown on figure 2). 
water induced from a source exterior to the aquifer system, such as a contamination source in the outcrop or salty reaches of the Delaware River (Delaware Memorial Bridge to Philadelphia), or the large body of salty ground water within the aquifer system. For example, the chloride concentrations of 16 and $21 \mathrm{mg} / \mathrm{L}$ at the site of well 6, (fig. 4), are probably related to the large body of salty ground water. The same conclusion is held for well 9 between sites 6 and 10, in which the chloride concentration was reported to be $19 \mathrm{mg} / \mathrm{L}$ (1963) at an altitude of about 1,083 ft below NGVD of 1929. (A. C. Schultes and Sons, Inc., personal communication, Dec. 28, 1976). On the basis of all available information, a broad transition zone has been delineated which is applicable to the aquifer system as a whole. The chloride distribution shown in figure 4 should be considered as a generalized first approximation because additional control points would reveal isochlorides that are more complex in extent and in depth.

No pumping wells in the southern part of the New Jersey Coastal Plain have been shutdown due to encroachment of the salty ground water although a substantial amount of ground water with a chloride concentration of less than $250 \mathrm{mg} / \mathrm{L}$ is being pumped near and within the transition zone. Most of the aquifer system within and south of the transition zone is encompassed by large cones of depression with heads reduced well below sea level. Consequently, salty ground water derived in part from the salty reaches of the Delaware River below Philadelphia is moving, however slowly, into the major pumping centers within and near the transition zone. 
Use of a digital model to study an aquifer is based on the premise that if past head changes within the aquifer can be simulated by the model, then so can those of the future. Head changes are determined by measuring water levels in wells. The historical period chosen for simulating past head changes was 1956-73. A starting (1956) head distribution in the aquifer system was input into the model, along with the head distribution over the confining layer, annual ground-water extraction rates (1956 through 1973), hydraulic properties of the aquifer system and confining layer, and sources of recharge from rivers and precipitation. The model calculated heads spatially on the bases of input data during the 18-year simulation period. Computed head distributions were used to compare the measured head distribution. Various parameters and/or boundary conditions were then modified and adjusted within tolerable limits until a good match or best fit was achieved between the observed and the calculated head changes. The model, which is an abstraction of the physical system, is then considered to have reached an acceptable level of performance to justify its use as a management tool.

\section{Computer Program and Mathematical Description}

The two-dimensional ground-water flow equation in a confined aquifer, if the $x$ and $y$ coordinates are alined with the principal components of the transmissivity tensor, can be approximately written as,

$$
\frac{\delta}{\delta x}\left(\mathrm{~T}_{\mathrm{x}} \frac{\delta \mathrm{h}}{\delta \mathrm{x}}\right)+\frac{\delta}{\delta \mathrm{y}}\left(\mathrm{T} \mathrm{y} \frac{\delta \mathrm{h}}{\delta \mathrm{y}}\right)=\mathrm{S} \frac{\delta \mathrm{h}}{\delta \mathrm{t}}+\frac{\mathrm{Q}}{\Delta \cdot \Delta \mathrm{y}}+\frac{\mathrm{K}}{\mathrm{m}}(\mathrm{H}-\mathrm{h})+\frac{\mathrm{R}}{\Delta \mathrm{x} \cdot \Delta \mathrm{y}}
$$

where

$$
\begin{aligned}
& h=\text { head, in feet; } \\
& T=\text { transmissivity, in cubic feet per second per foot; } \\
& S=\text { storage coefficient (dimensionless); } \\
& Q=\text { rate of ground-water extraction or injection, in } \\
& \text { cubic feet per second; } \\
& R=\text { recharge, in cubic feet per second; } \\
& K=\text { vertical hydraulic conductivity of the confining layer, } \\
& \text { in feet per second; } \\
& m=\text { thickness of the confining layer, in feet; } \\
& \mathrm{H}=\text { head in a sub-or superjacent aquifer, or in a stream } \\
& \text { over the confining layer, in feet; } \\
& \mathrm{x}, \mathrm{y}=\text { rectangular coordinates, in feet; } \\
& \Delta x, \Delta y=\text { space increments, in feet; } \\
& t=t \text { ime, in seconds. }
\end{aligned}
$$

Equation 1 is approximately solved by using a finitedifference method described by Pinder and Bredehoeft (1968, $\mathrm{p}$. 1073-1075), Pinder (1970), and Trescott and others (1976). Figure 5 is a flow chart of the computer program and the digital model. The finite-difference method approximates the surface of the 


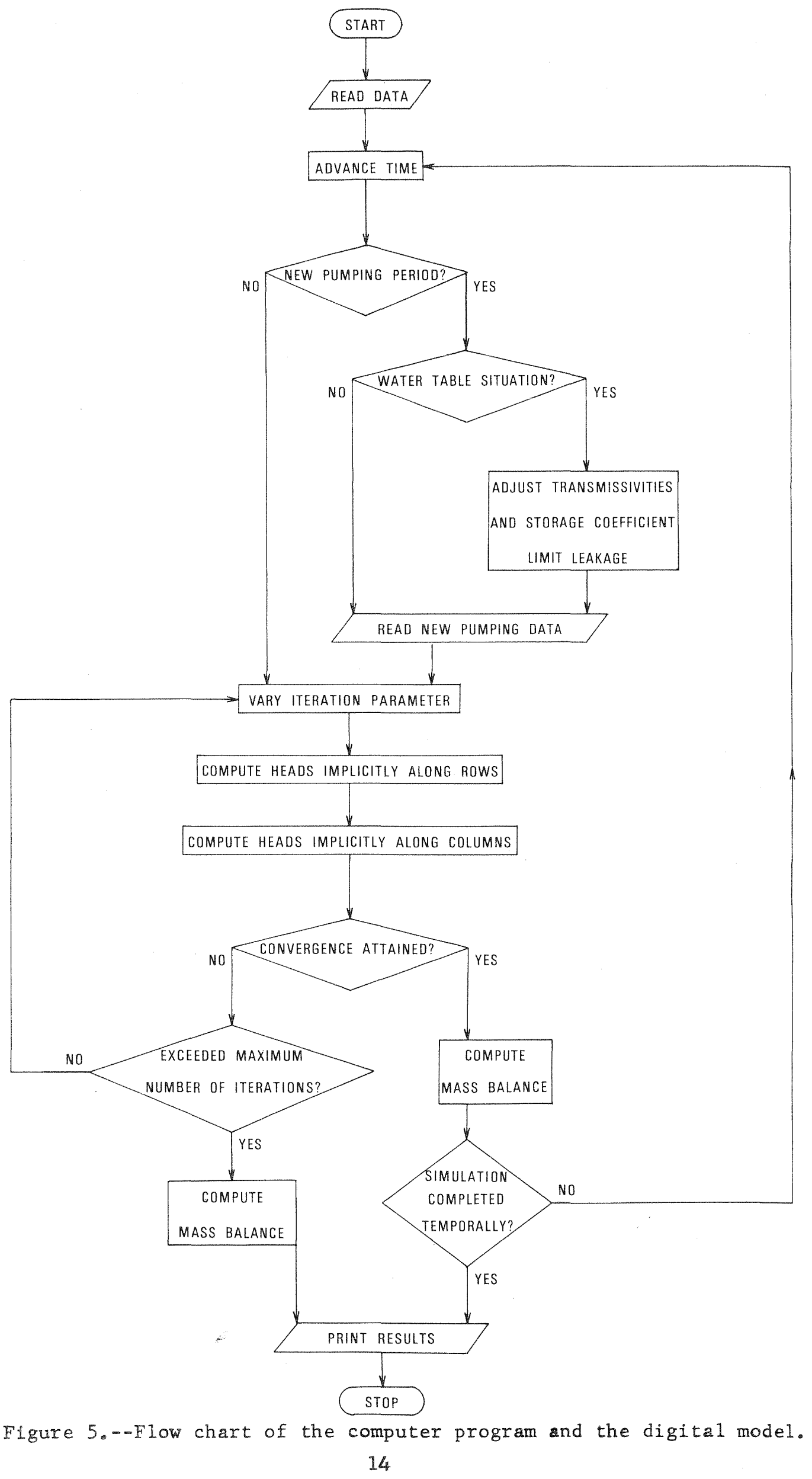


aquifer system by a mesh of elements (fig. 6). At the center of each element is a node where data are either given or computed.

An iterative, alternating-direction implicit method was used to solve simultaneously equations which describe the head at each node. Equation 1 is time dependent and time in the numerical model used is advanced in increments which are one and one-half times the previous time step. At each time step, an iterative process is carried out to achieve a head solution; head distributions computed in successive iterations are compared. For each node, when the difference between the head computed in one iteration and that computed in the succeeding iteration is less than an assumed limit, error of closure, the solution for that time step is achieved. A pumping period is considered either as one time step or many time steps during a simulation, and each time step ends with a complete head distribution calculated by the model.

Table 2 shows how computations are advanced through time with the typical number of iterations required during each time step. In selecting the time sequence and closure criterion, trial runs were made initially, using more than twice as many time steps as shown and with closure tolerances ranging from 0.01 to $1 \mathrm{ft}$. The comparison of closure criteria of 0.5 and $0.05 \mathrm{ft}$, shown in table 2, resulted in nearly a doubling of iterations, and thus computation time. Calculated head differences after 18 years differed by only 0.07 to 0.2 ft for the two closure criteria. Therefore, $0.5 \mathrm{ft}$ has been used in all runs with little sacrifice in accuracy and a great savings in computer time.

The model used in this investigation was developed from the model in Pinder (1970); however, several changes in the computational method were made:

1. Transient leakage through confining layers is not included in the model. Only steady leakage defined as $\mathrm{K} / \mathrm{m}(\mathrm{H}-\mathrm{h})$ (equation $\mathrm{l}$ ) is used.

2. The method of simulating constant head boundaries was changed. Pinder (1970) used a high leakage coefficient at nodes where a constant head was specified in order to force aquifer heads to be almost equal to the constant head in the confining unit. The program was changed so that the solution routine skips head calculation at constant head nodes.

3. Conversion from water table conditions to artesian conditions and vice versa was added to the model. The method is similar to, but not as rigorous as, that used by Trescott (1976, p. 10-11). At the start of a pumping period, transmissivity is computed as saturated thickness of the aquifer tines hydraulic conductivity. Specific yield is used for storage coefficient if aquifer head is below the aquifer top at the start of the pumping period. Otherwise, a confined storage coefficient is used. The effect of testing 


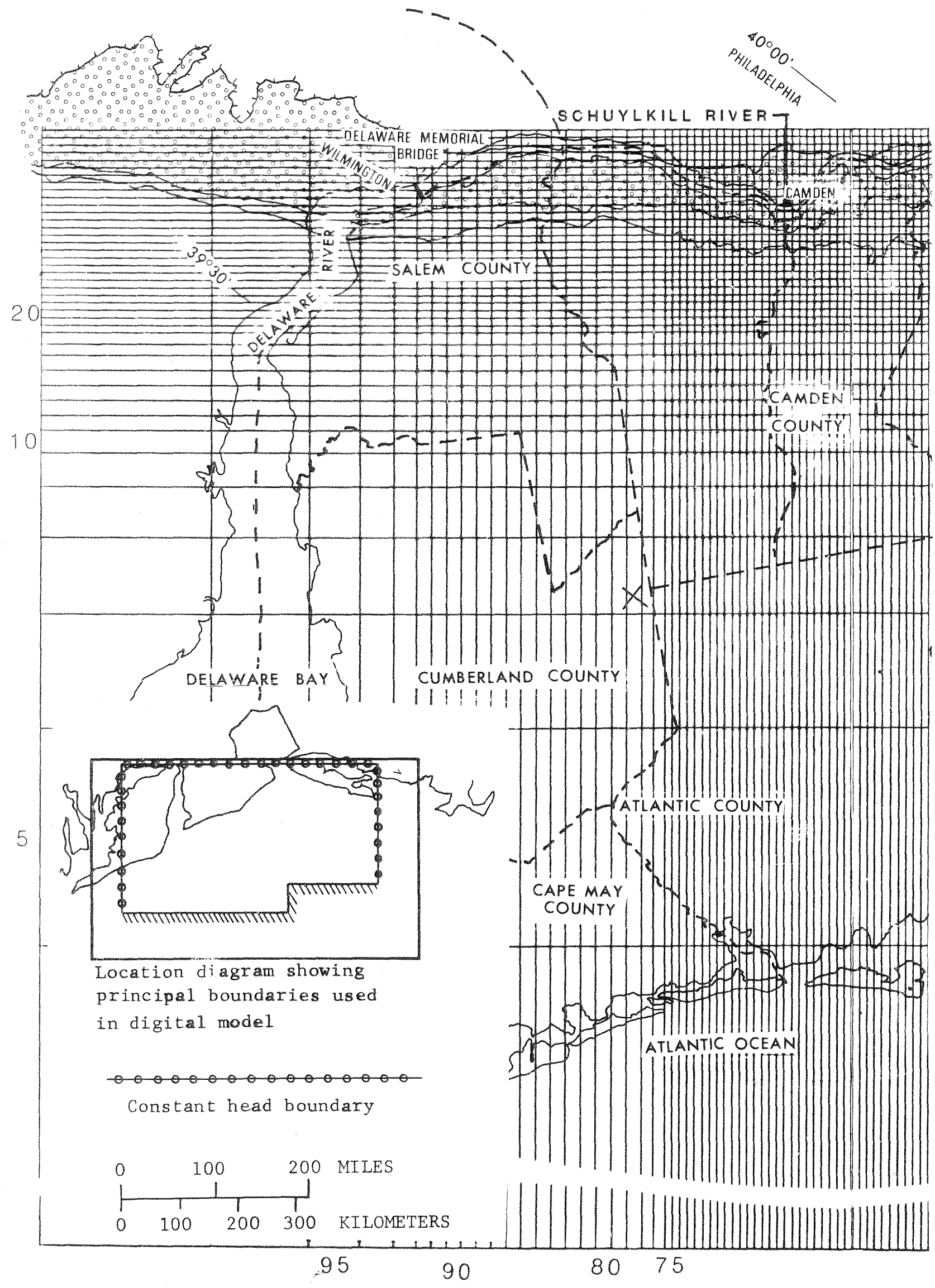

Figure 6.--Finite difference grid and 


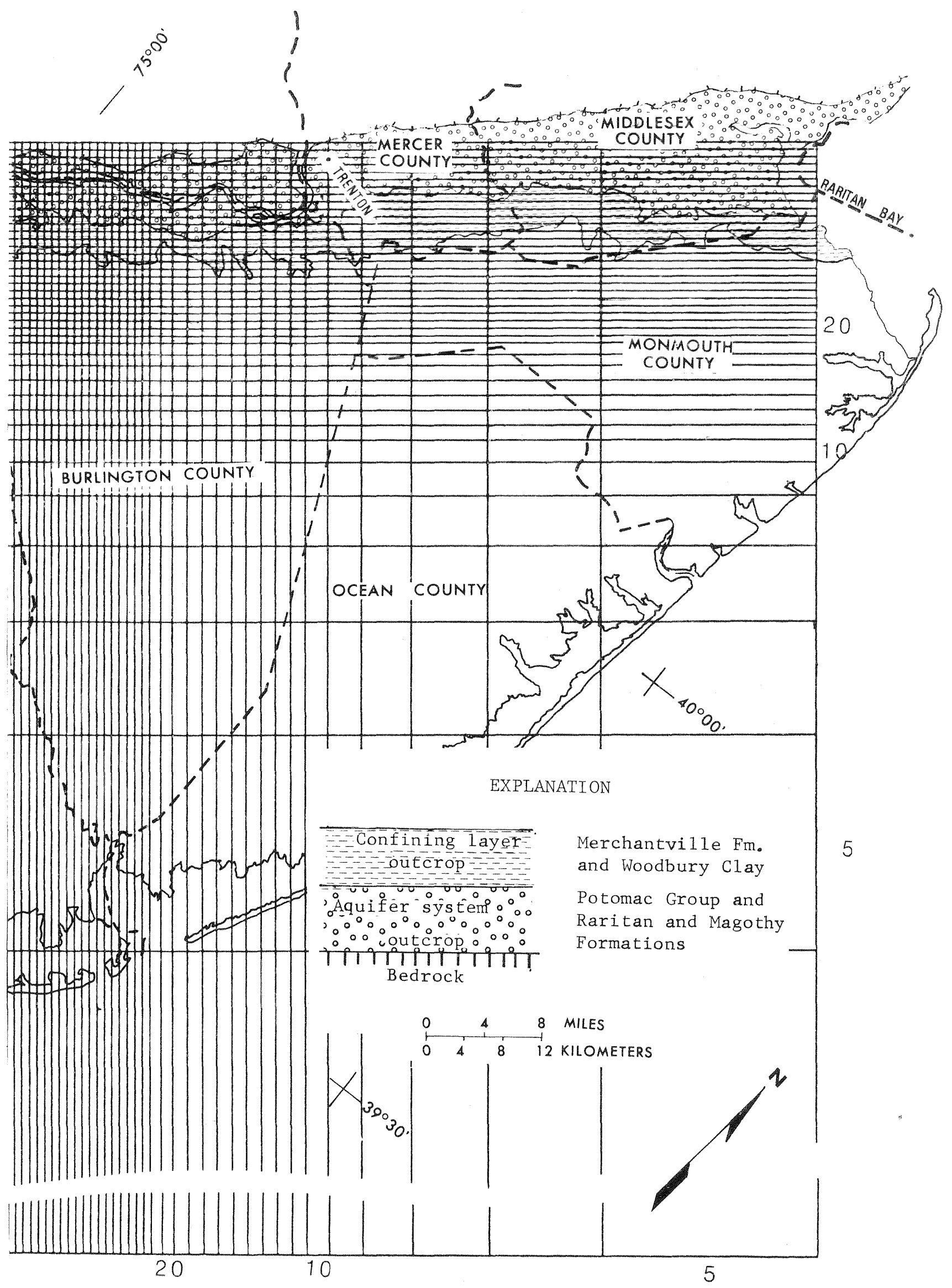

boundaries used in the digital model. 
Table 2.--Time step sequencing used in the digital model, 1956-2000

\begin{tabular}{|c|c|c|c|c|c|c|c|}
\hline \multicolumn{2}{|r|}{ Year } & $\begin{array}{l}\text { Time step } \\
\text { number }\end{array}$ & $\begin{array}{l}\text { Length of } \\
\text { time step } \\
\text { (days) }\end{array}$ & $\begin{array}{l}\text { Days since } \\
\text { start of } \\
\text { pumping } \\
\text { period }\end{array}$ & $\begin{array}{l}\text { Elapsed time } \\
\text { since start } \\
\text { of pumping } \\
\text { (days) }\end{array}$ & \multicolumn{2}{|c|}{$\begin{array}{l}\text { Typical number of } \\
\text { iterations required } \\
\text { to calculate new head } \\
\text { within closure of } \\
0.5 \mathrm{ft} \quad 0.05 \mathrm{ft}\end{array}$} \\
\hline 1956 & $(1 s t)$ & $\begin{array}{l}1 \\
2 \\
3 \\
4 \\
5 \\
6 \\
7 \\
8\end{array}$ & $\begin{array}{r}7.42 \\
11.12 \\
16.68 \\
25.03 \\
37.54 \\
56.31 \\
84.46 \\
126.69\end{array}$ & $\begin{array}{r}7.42 \\
18.54 \\
35.22 \\
60.25 \\
97.79 \\
154.10 \\
238.56 \\
365.25\end{array}$ & $\begin{array}{r}7.42 \\
18.54 \\
35.22 \\
60.25 \\
97.79 \\
154.10 \\
238.56 \\
365.25\end{array}$ & $\begin{array}{l}11 \\
6 \\
4 \\
4 \\
5 \\
4 \\
5 \\
4\end{array}$ & $\begin{array}{r}17 \\
11 \\
11 \\
8 \\
8 \\
6 \\
5 \\
5\end{array}$ \\
\hline 1957 & $(2 n d)$ & $\begin{array}{r}9 \\
10 \\
11 \\
12\end{array}$ & $\begin{array}{r}44.95 \\
67.43 \\
101.15 \\
151.72\end{array}$ & $\begin{array}{r}44.95 \\
112.38 \\
213.53 \\
365.25\end{array}$ & $\begin{array}{l}410.20 \\
477.63 \\
578.78 \\
730.50\end{array}$ & $\begin{array}{r}11 \\
3 \\
4 \\
4 \\
65\end{array}$ & $\begin{array}{r}17 \\
10 \\
10 \\
9 \\
117\end{array}$ \\
\hline 1958 & $(3 r d)$ & 16 & & & $1,095.75$ & & \\
\hline 1973 & $(18 t h)$ & $\begin{array}{l}\text { (End of } \\
\text { simulation } \\
\text { period) }\end{array}$ & $\begin{array}{l}{[1957 \mathrm{sec}} \\
\text { for all }\end{array}$ & $\begin{array}{l}\text { repeated } \\
\text { ding years] }\end{array}$ & $6,574.50$ & & \\
\hline 2000 & $(44 t h)$ & $\begin{array}{l}180 \text { or } 192 * \\
\text { (End of } \\
\text { projections) }\end{array}$ & & & $16,071.00$ & & \\
\hline
\end{tabular}

* During one projection described later, in which a freshwater injection barrier was emplaced in 1984, the number of time steps was increased that year from 4 to 16

to prevent any possibility of inducing error because of the sudden change in stress. 
for water table/artesian conversion at the start of a pumping period rather than every iteration as Trescott (1978) does is considered small for the conditions simulated in this report. Heads throughout the aquifer system are generally declining at a slow rate of $3 \mathrm{ft} / \mathrm{yr}$ or less. If much greater rates of head change are simulated, then significant errors could occur.

Output modifications to this model include automatically scaled page size hydrographs and a map of head difference between observed and computed surfaces for any given year. In addition, ground-water budget computations, normally computed only for the entire model, have been modified to give a complete analysis for the principal area of interest, the fine-grid area.

\section{Grid Size and Boundaries}

The grid size consists of a fine grid of 2,800 elements in the Burlington, Camden, Gloucester, and Salem County areas surrounded by a coarse, variable sized grid of 1,600 elements (fig. 6). Within the fine-grid area, element sizes range from $0.25 \mathrm{mi}^{2}$ with side dimensions of $2,640 \mathrm{ft}$, to $1 \mathrm{mi}^{2}$ with side dimensions of $5,280 \mathrm{ft}$. About 1,100 $\mathrm{mi}^{2}$ of $\mathrm{l}$ and and water surfaces are covered by the fine grid, which is $54 \mathrm{mi}$ long and 20 mi wide; whereas, many thousands of square miles are covered by the coarse grid.

The small element sizes in the fine grid were chosen to define pumping centers, the outcrop belt, and the Delaware and Schuylkill Rivers. Outside the fine-grid area, the definition capability progressively decreases as the element sizes become quite large or very long and narrow (fig.6). Grid expansion outside the fine-grid area allows incorporation of the rest of the aquifer system, including pumping centers, without a prohibitive increase in computer cost. However, simulation and predictive capability become progressively more generalized with distance from the boundaries of the fine grid because of the coarseness of data definition.

The Potomac-Raritan-Magothy aquifer system is extensive and the boundaries distant from the outcrop area are uncertain. Therefore, the coarse grid has been extended seaward to include the continental slope about $100 \mathrm{mi}$ off the New Jersey coast. It has also been extended to the northeast about $100 \mathrm{mi}$ from Raritan Bay and to the southwest about $40 \mathrm{mi}$ from Delaware Bay (fig. 6). These last two "side" boundaries are treated in the model as infinite sources of water (constant heads). This approximation is clearly an arbitrary truncation of the aquifer system, but at such a great distance from the area of interest, the error resulting from fixing heads along the boundaries due to pumping stresses in the fine-grid area are assumed to be negligible. The seaward boundary, which is roughly parallel to the continental slope, is treated as an impermeable or no-flow boundary. According to Sheridan and Knebel (1976, p. 1112-1117), high resolution seismic 
profiles near the continental slope show evidence of high angle norinal faults from near surface to depths of 3.7 to $4.0 \mathrm{mi}$. In deeper beds, thought to be of Early Cretaceous age, $295 \mathrm{ft}$ of vertical movement has been detected. According to Sheridan and Knebel (1976, p. 1113), "The position and strike of these faults coincide with and parallel the East coast magnetic anomaly interpreted as the fundamental seaward basement boundary of the Baltimore Canyon trough." The large vertical movement associated with the fault zone probably provides evidence for termination of permeable beds and; therefore, the continental slope is treated as a no-flow boundary.

A fourth major boundary, for which a great deal of hydrologic and geologic evidence is available, lies roughly parallel to the outcrop of the aquifer system and extends to the Fall Line adjacent to the New Jersey Coastal PIain. This boundary was simulated as having two distinctly different hydrologic characteristics, depending on the occurrence of extensive clays in the shallow part of the aquifer system. In most of the outcrop belt south of Trenton, the Potomac-Raritan-Magothy aquifer system is entrenched by the southwestwardly flowing Delaware River. This area of the aquifer system was modeled as being constant head. Based on evidence which included water quality, temperature and head gradients, Barksdale and others (1958, p. 101-128) recognized that induced recharge from the Delaware River accounted for a substantial portion of the total water withdrawn from the aquifer in the vicinity of the river course. Furthermore, the potential for induced recharge was estimated to be 4 to 10 million gallons per day (Mgal/d) per mile of aquifer along the river. The condition of the river bottom was considered the most important factor in controlling induced recharge. Only a few feet of clay or silt would greatly reduce the amount of water that could infiltrate the aquifer. In a study of the effects of a proposed enlargement and deepening of a ship channel (Philadelphia to Trenton) from a depth of $25 \mathrm{ft}$ to a depth of $45 \mathrm{ft}$, the consulting firms of Powell, and Leggette and Brashears (1954, Appendix A2-1), concluded on the bases of boring and pumping tests that:

(1) Deposits of highly permeable sand and gravel are in contact with the river in the central channel, while finer grained material is normally present in the shallows between the excavated channel and the river banks.

(2) The major portion of induced recharge to nearby well fields in New Jersey probably occurs along the excavated channel bottom.

(3) In most major well fields near the river in Camden and Burlington Counties, induced recharge would account for 50 to 80 percent of production after prolonged pumping. 
(4) The proposed channel enlargement and deepening to 45 ft would increase the effective area of infiltration by 30

percent and expose more of the highly permeable stratified zones of the aquifer.

The ship channel has since been enlarged and is now maintained to a depth of about $45 \mathrm{ft}$.

Barksdale and others (1958, p. 115-116) indicated that within one reach of the Delaware River between Camden and Philadelphia, induced recharge probably cannot occur to much extent. A thick clay bed extends within the Raritan Formation beneath the river effectively isolating the lower beds. A sinilar condition exists near the soutrwestern edge of the fine grid near the Delaware Memorial Bridge. Much of the aquifer system cropping out there is composed of thick clay beds which isolate the lower beds from the Delaware River. Clay beds in this reach of the river, and the reach in Philadelphia, are simulated as part of the Merchantville-Woodbury confining layer.

\section{Hydrologic Parameters}

Transmissivity

Estimates of sand percentages of the aquifer thickness and estimates of permeability on the basis of specific capacity per foot of screen length, gallons per minute per foot squared [(gal/min)/ft $\left.{ }^{2}\right]$ were incorporated into the computer program. According to Farlekas and others (1976, p. 39), specific capacities per foot of. well screen observed in 95 wells, 12 inches in diameter or larger, in Camden County ranged from 0.12 to 2.29. They found that wells in the outcrop area had the highest average specific capacities per foot of well screen $\left[0.95\right.$ (gal/min)/ft ${ }^{2}$ for 50 wells]. For the remaining 35 wells located downdip from the outcrop the average specific capacity per foot of well screen was 0.52 . The higher specific capacities in the outcrop area were attributed to better hydraulic properties and to the proximity of recharge, particularly the Delaware River. Geophysical logs clearly show that the thickest sand beds in the aquifer system generally occur in a belt along the outcrop, with a rapid thinning of sand beds and multiple interfingerings with clay and silt beds downdip towards the coast. Using the data presented by Farlekas and others (1976) and the sand percentages of the thickness of the aquifer system estimated from geophysical logs, the initial transmissivity distribution was generated on the bases of the following assumptions:

(1) Eifty percent of the thickness in the outcrop is sand, with a specific capacity per foot of sand of $1.0(\mathrm{gal} / \mathrm{min}) / \mathrm{ft}^{2}$. 
(2) In the area underlying the outcrop of the Merchantville Formation-Woodbury Clay (fig. 6), about 2 to $3 \mathrm{mi}$ in width, sand percentage is 40 percent with a specific capacity per foot of sand also equal to 1.0

(gal/min) $/ f t^{2}$.

(3) From the outcrop area to $10 \mathrm{mi}$ downdip (to row 14 , fig. 6), sand was estimated to be 35 percent of the total thickness with a specific capacity per foot of sand of $0.6(\mathrm{gal} / \mathrm{min}) / \mathrm{ft}^{2}$.

(4) From row 13 to row 8 (fig. 6), a distance of another 10 mi, sand was estimated to be 25 percent of the total thickness, with a specific capacity per foot of sand of $0.4(\mathrm{gal} / \mathrm{min}) / \mathrm{ft}^{2}$.

(5) From row 7 to the seaward edge of the model, row 2 (fig. 6), a distance of about $137 \mathrm{mi}$, sand was estimated to be 20 percent of the total thickness with a specific capacity per foot of sand of 0.2 ( $\mathrm{gal} / \mathrm{min}) / \mathrm{ft}^{2}$.

Transmissivity was calculated by an equation presented by Lohman (1972, p. 52). The equation is given by,

where,

$$
\frac{Q}{\mathrm{~S}_{W}} \simeq \frac{4 \pi \mathrm{KL}}{2.30 \log _{10}\left(2.25 \mathrm{KLt} / \mathrm{r}_{\mathrm{W}}{ }^{2} \mathrm{~S}\right)}
$$

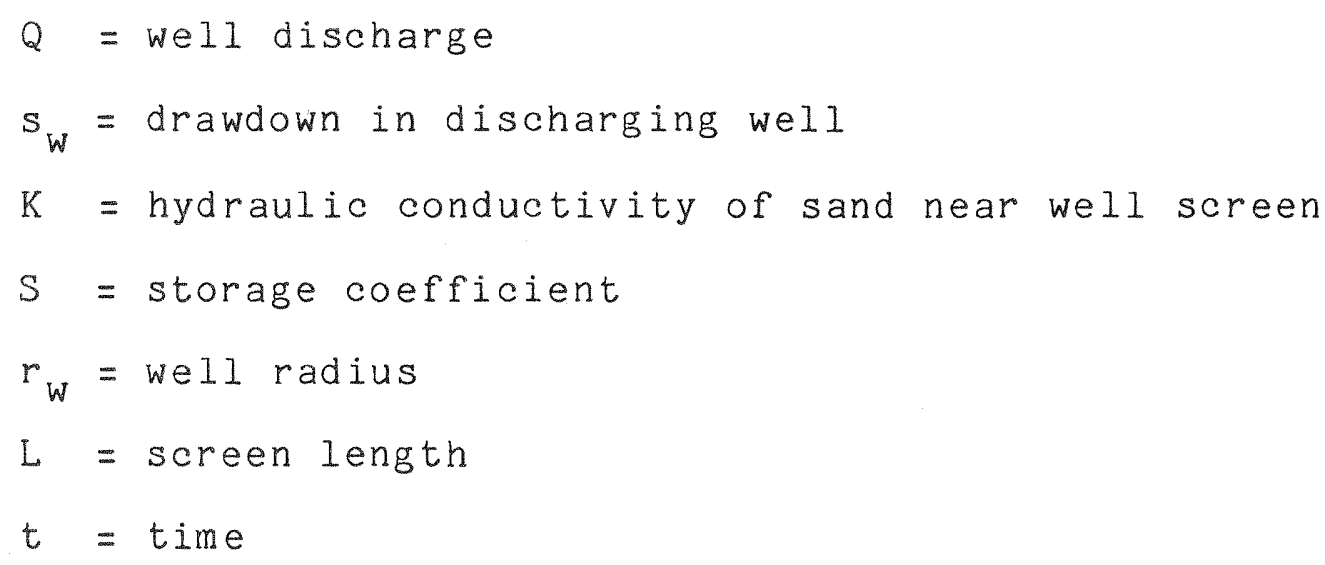

The reason for replacing $T$ in the equation by $K L$ is that the earlier work by Farlekas and others (1976) could be directly incorporated into the computer calculation. The replacement is valid only if the screened interval (L) is equal to the thickness of the saturated sand trat efteatively contributes to flow to the well. However, most lar :e diameter wells in the study area meet this criterion; therefor:, the replacement is tolerable. Rearranging equation. (2) a d letting b represent the aquifer thickness times percentage of sand, the transmissivity of the aquifer $(T=K b)$ is give by, 


$$
T=.183(b) \quad\left(\frac{Q}{S_{W}^{L}}\right) \log _{10}\left(\frac{2.25 \mathrm{TLt}}{r_{W}{ }^{2} \mathrm{Sb}}\right)
$$

The value of the log term in the above equation is estimated to range from about 6 to 7 for typical large diameter wells (12-inch screen with 12-inch gravel pack) having 8-hour aquifer tests. A value of 6 was arbitrarily assigned for the log term to determine initial transmissivity distribution.

The vicinity of well 4 ( $f i g .2$ ) was used as an example to show the computation of transmissivity. Figures 2 and 3 indicate that the total thickness of the aquifer system near well 4 is about $200 \mathrm{ft}$. The location of well 4 is in the outcrop area; therefore, $b=100 \mathrm{ft}(50$ percent of $200 \mathrm{ft}$ ). The specific capacity per foot of screen $\left(Q / s_{W} L\right)$ is assuned to be 1.0 $(\mathrm{gal} / \mathrm{min}) / \mathrm{ft}^{2}$, then,

$$
\begin{aligned}
T & =\frac{0.183(100 \mathrm{ft})\left(1(\mathrm{gal} / \mathrm{min}) / \mathrm{ft}^{2}\right)(1440 \mathrm{~min} / \mathrm{day})(6)}{7.48 \mathrm{gal} / \mathrm{ft}^{3}} \\
& =21,100 \mathrm{ft} 2 / \mathrm{day}
\end{aligned}
$$

Figure 7 is the final transmissivity distribution used in the model. It should be noted that transmissivity in the vicinity of well 4 is $23,000 \mathrm{ft}^{2} /$ day instead of $21,100 \mathrm{ft}^{2} / \mathrm{day}$. The difference reflects adjustments made during the simulation runs. In general, adjustments in transmissivity were less than 20 percent in and within $6 \mathrm{mi}$ of the outcrop belt. Further downdip, the transmissivity distribution generated by the described approach was reduced by 20 to 60 percent. These reductions were made during simulation runs together with other adjustments, such as leakage through the confining layer.

Transmissivity adjustments affected the slope of the computed hydrograph trends. Vertical departure from the observed trends in confined portions of the aquifer was controlled chiefly by adjustments to leakage through the confining layer.

\section{Storage Coefficient}

The storage coefficient in the outcrop area is assumed to be $8 \times 10^{-3}$. This is an approximation to allow for the prevalence of interlayered sand and clay beds within the outcrop, thus causing both water-table and confined conditions. For the clearly confined portions of the aquifer system, the storage coefficient is probably within the range of 2 to $6 \times 10^{-4}$. It could reach a minimum of $8 \times 10^{-5}$ in the southwest end of the model in the area roughly enclosed by the $10,000 \mathrm{ft}^{2} / \mathrm{day}$ transmissivity line that passes near wells 1 and 13 ( $\mathrm{fig}$. 7). These values approximately agree with those reported by Barksdale and others (1958, p. 97) and Rush (1968, p. 33). The model was found to be relatively insensitive to storage coefficient, particularly in the outcrop area. Constant-head nodes, such as those used to simulate the 


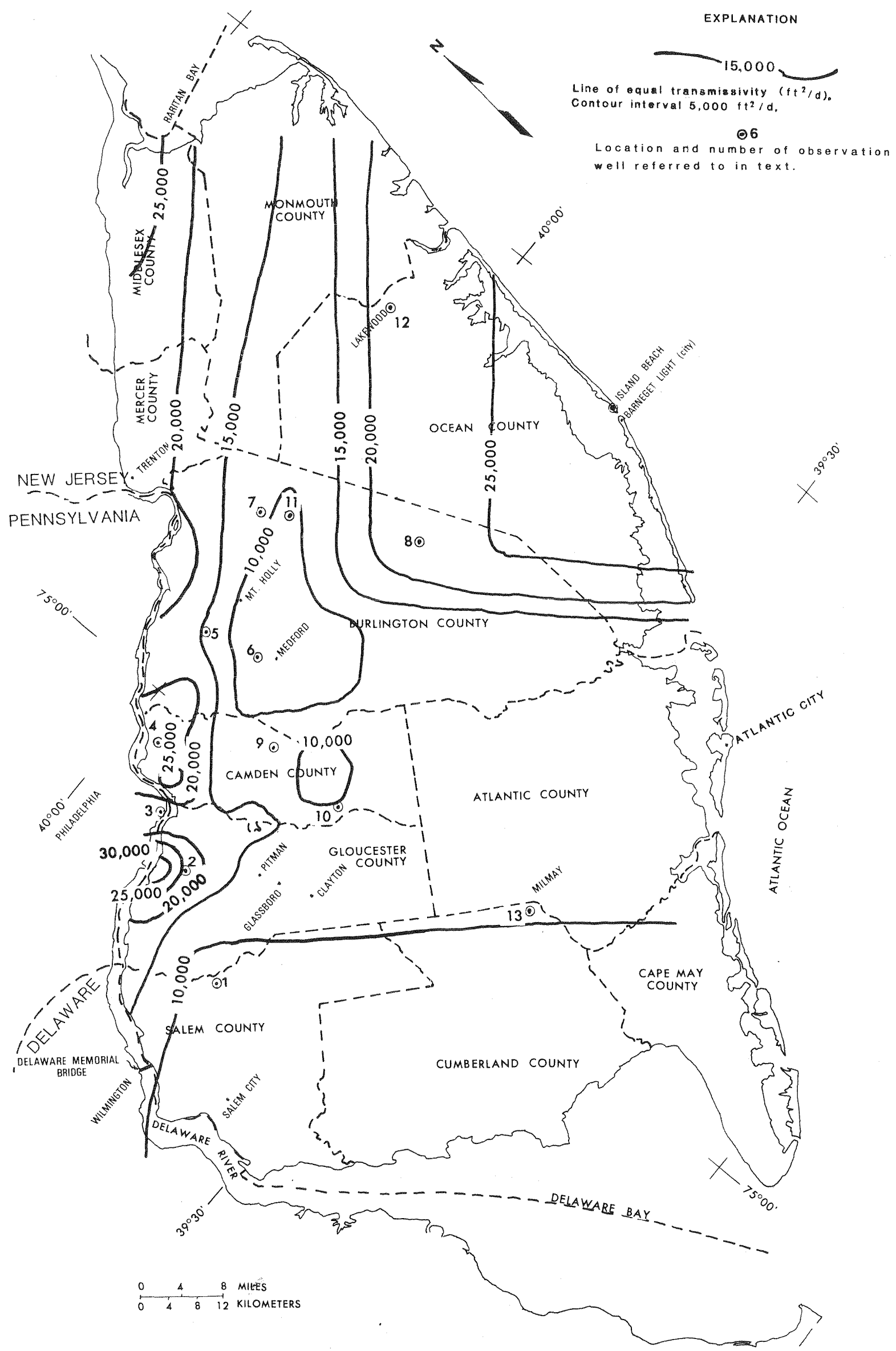

Figure 7.--Distribution of transmissivity used in the model for the PotomacRaritan-Magothy aquifer system. 
Delaware River, tended to mask out such influence in adjacent nodes of the narrow outcrop strip.

The storage coefficient used in the confined portions of the aquifer system is allowed to convert to the same order of magnitude used in the outcrop area if the head falls below the top of the aquifer system. This is an approximation; actually, the conversion is probably more complicated and slower. By the end of 1973, heads had dropped below the bottom of the overlying confining layer in a relatively small area near the outcrop in Camden County.

As indicated previously, the fine-grained beds become more prominent in the aquifer system downdip from the outcrop. The great thickness of silt and clay may have higher storage coefficient than the aquifer material. The aquifer storage coefficient, therefore, includes the combined storage properties of the aquifer material and the fine-grained material. This is an approxination that is valid when the fine-grained beds are relatively thin and well distributed throughout the aquifer (Jacob, p. 577).

\section{Confining Layer}

The Merchantville Formation and Woodbury Clay together constitute one of the most widespread confining layers in the Coastal Plain of New Jersey (fig. 8). The combined thickness increases downdip to more than $300 \mathrm{ft}$ along the coast and to more than $500 \mathrm{ft}$ offshore. The stratigraphy of the two units is discussed in detail by Perry and others (1975), Owens and others (1970), Petters (1976), and in lesser detail by workers cited earlier. The two units are considered to be of Late cretaceous age and consist of dark-grey, micaceous silty-clay, or clayey silt containing marine fossils. According to Petters (1976, p. 87), the Merchantville Formation was deposited as the offshore facies of the Magothy Formation during a marine transgression, followed by the Woodbury Clay as the shoal facies. Furthermore, according to Petters (1976, p. 102), the Woodbury Clay may interfinger with the overlying Englishtown Formation in some downdip regions.

In the model, transient leakage from the confining layer is ignored. The possibility for significant leakage does exist, especially downdip where the confining unit thickens. While the model was successfully calibrated without including transient leakage, users should be aware that other stress conditions might cause erroneous results because of this assumption. Downdip development of the aquifer system would be the most likely stress to cause such problems.

Laboratory determined vertical hydraulic conductivities of cores from wells at Lakewood, N.J., and at Fort Dix are included in table 3. The vertical hydraulic conductivities were measured in the laboratory through a range of simulated overburden pressures or effective stresses existing in the coastal plain. As 


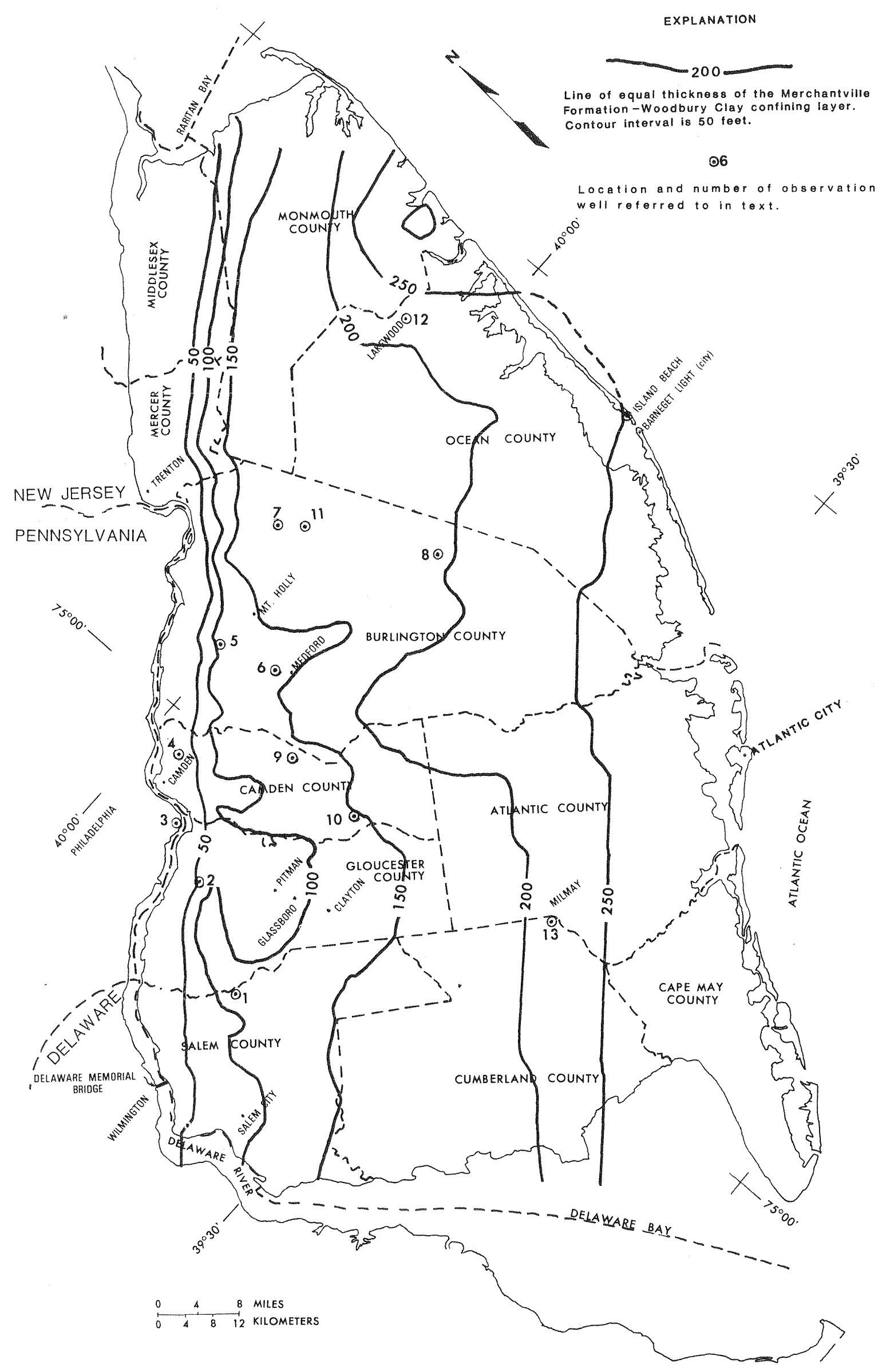

Figure 8.--Thickness of the Merchantville Formation-Woodbury Clay confining layer (modified from H. E. Gill, personal communication, 1974). 
Table 3.--Laboratory determined vertical hydraulic conductivities of the Merchantville Formation and Woodbury Clay determined from cores.

\begin{tabular}{|c|c|c|c|c|}
\hline $\begin{array}{l}\text { Well No and } \\
\text { location } \\
\text { (see fig. 6) }\end{array}$ & $\begin{array}{l}\text { Coring } \\
\text { depth } \\
(f t)\end{array}$ & $\begin{array}{l}\text { Simulated effective earth } \\
\text { stress in pound-force per } \\
\text { square inch (psi), and } \\
\text { equivalent depths of burial } \\
\text { (psi) }\end{array}$ & $(f t)$ & $\begin{array}{c}\text { Vertical } \\
\text { hydraulic } \\
\text { conductivity }(\mathrm{K}) \\
(\mathrm{ft} / \mathrm{s})\end{array}$ \\
\hline \multirow[t]{4}{*}{$\begin{array}{l}\text { Lakewood Water } \\
\text { Co. Well } 10 \\
\text { (Well 12) } \\
\text { (on fig. 6) }\end{array}$} & 795 & $\begin{array}{r}(130) \\
(800) \\
(1,500)\end{array}$ & & $\begin{array}{l}4.93 \times 10^{-10} \\
4.18 \times 10^{-11} \\
1.67 \times 10^{-11}\end{array}$ \\
\hline & 845 & $\begin{array}{r}(150) \\
(850) \\
(1,550)\end{array}$ & & $\begin{array}{l}1.63 \times 10^{-9} \\
5.32 \times 10^{-11} \\
8.35 \times 10^{-12}\end{array}$ \\
\hline & 896 & $\begin{array}{r}(200) \\
(900) \\
(1,600)\end{array}$ & & $\begin{array}{l}4.94 \times 10^{-10} \\
5.69 \times 10^{-11} \\
1.44 \times 10^{-11}\end{array}$ \\
\hline & 928 & $\begin{array}{r}(250) \\
(900) \\
(1,600)\end{array}$ & & $\begin{array}{l}5.69 \times 10^{-10} \\
1.63 \times 10^{-10} \\
1.18 \times 10^{-10}\end{array}$ \\
\hline \multirow[t]{4}{*}{$\begin{array}{l}\text { U.S. Army Ft. } \\
\text { Dix Well } 6 \\
\text { (Well 11) } \\
\text { (on fig. 6) }\end{array}$} & 523 & $\begin{array}{l}(150) \\
(300) \\
(500)\end{array}$ & & $\begin{array}{l}1.44 \times 10^{-10} \\
8.83 \times 10^{-11} \\
1.39 \times 10^{-10}\end{array}$ \\
\hline & 546 & $\begin{array}{r}(150) \\
(300) \\
(600) \\
(1,150)\end{array}$ & & $\begin{array}{l}7.62 \times 10^{-11} \\
6.07 \times 10^{-11} \\
4.25 \times 10^{-11} \\
3.20 \times 10^{-11}\end{array}$ \\
\hline & 569 & $\begin{array}{r}(150) \\
(300) \\
(600) \\
(1,150)\end{array}$ & & $\begin{array}{l}2.70 \times 10^{-10} \\
1.42 \times 10^{-10} \\
9.33 \times 10^{-11} \\
8.67 \times 10^{-11}\end{array}$ \\
\hline & 625 & $\begin{array}{r}(150) \\
(300) \\
(600) \\
(1,150)\end{array}$ & & $\begin{array}{l}1.22 \times 10^{-9} \\
6.39 \times 10^{-10} \\
3.46 \times 10^{-10} \\
1.92 \times 10^{-10}\end{array}$ \\
\hline
\end{tabular}


With most coring operations, the selection of coring intervals is somewhat biased by ease in core recovery towards the finer-grained and, therefore, tighter horizons in the formation. Most of the magnitudes of vertical hydraulic conductivities used in the final model ( $f i g .9$ ) fall within the range of values shown in table 3 . In addition, most cores show decreasing hydraulic conductivities as depths of burial increase. This decreasing trend is also strongly apparent from figure 9 which shows a downdip decrease in vertical hydraulic conductivity of the confining layer. Beyond the $1 \times 10^{-10} \mathrm{ft} / \mathrm{s}$ contour line, all values fall within the range of 1 to $8 \times 10^{-11} \mathrm{ft} / \mathrm{s}$, with the minimum value farthest downdip.

An extension in the model of the Merchantville-Woodbury confining layer was made in the Philadelphia area and near the Delaware Memorial Bridge (see fig. 9) in order to better approximate field conditions. The thickness of the confining layer modeled for the Philadelphia area ranged approximately from 10 to $90 \mathrm{ft}$ as based on the thickness of a confining layer mapped by Greenman and others (1961, pl. 18). For the area near the Delaware Memorial Bridge, an arbitrary thickness of $100 \mathrm{ft}$ was assigned.

\section{Recharge from Overlying Aquifers and Precipitation}

Recharge to the confined portion of the aquifer system is modeled primarily as steady leakage passing through the Merchantville Formation-Woodbury Clay confining layer from the overlying Englishtown and the Wenonah-Mount Laurel aquifers. These two aquifers seem to function together as a hydrologic system in areas of Ocean and Monmouth Counties where detailed studies have been made (Nemickas, 1976 and Nichols, 1977). In addition, throughout most of the coastal plain the head distribution of each aquifer is similar. In much of southern New Jersey, the Englishtown Formation is a confining unit (Nemickas, $1976, \mathrm{p} .21$ ).

The overlying head distribution used in the model as the driving force for steady leakage is chiefly that of the Wenonah-Mount Laurel aquifer in southern New Jersey ( $f i g .10)$, and is a composite head with that of the Englishtown aquifer in the eastern and northeastern parts of the coastal plain. Where the confining layer is exposed at land surface, the modeled overlying head is set equal to shallow water levels and streams. For those outcrop areas in which an extension of the confining layer ( $f i g$. 9) has been used, the overlying head is the water table as defined by wells, streams, and swamps.

Figure 11 shows a perspective view of the overlying head distribution. The depression below sea level, on the right side of figure 11, is caused by pumping in both the Englishtown and Wenonah-Mount Laurel aquifers along coastal Ocean and Monmouth Counties. Heads observed in that area were approximately 20 to 80 ft below mean sea level in 1959 (Nemickas, 1976, p. 16, and Nichols, 1977, p. 29). By fall of 1973, the heads dropped to 


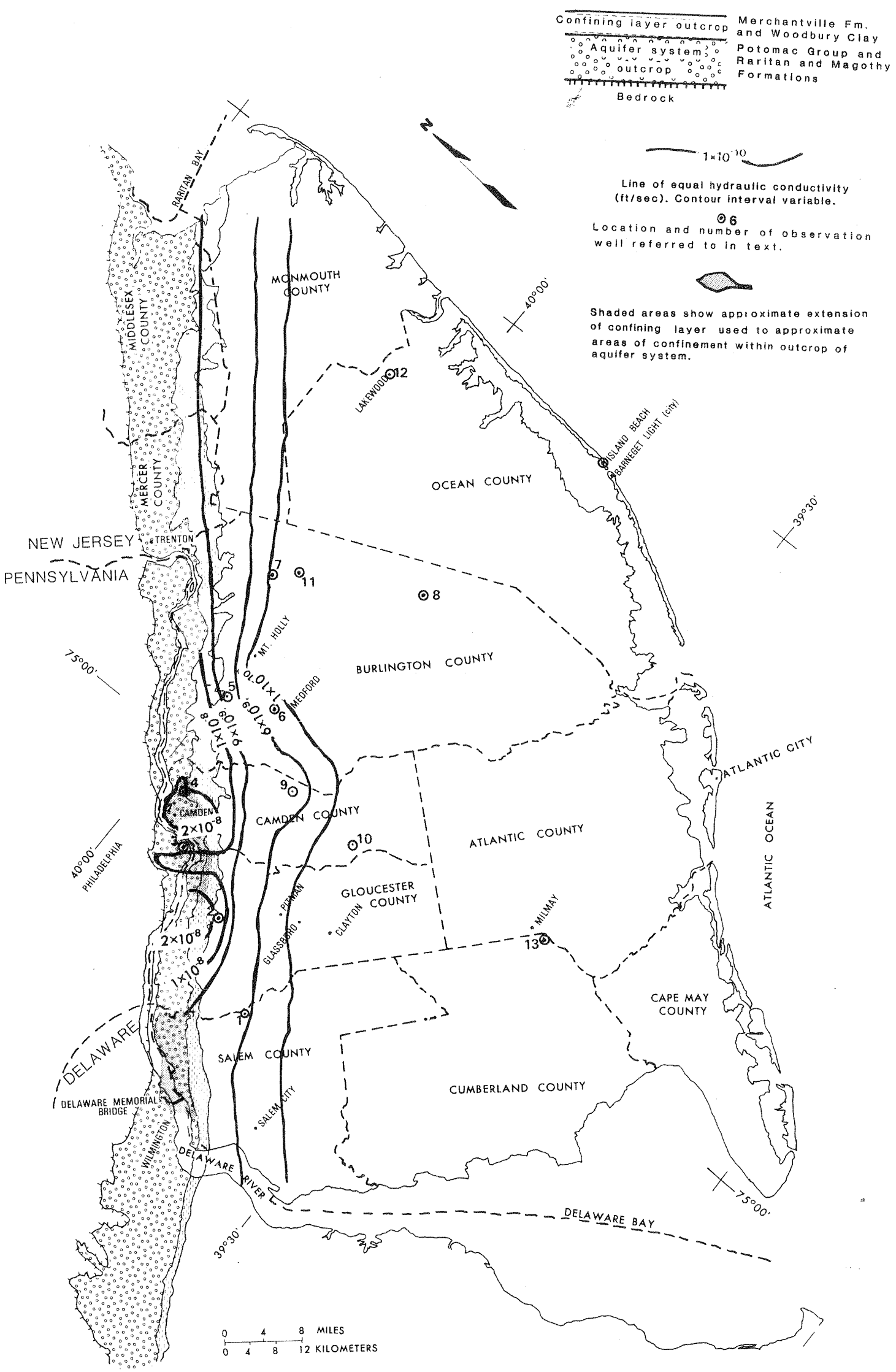

Figure 9.- Distribution of vertical hydraulic conductivity of the Merchantville Forrationm Woodbury Clay confining layer used in the model. 


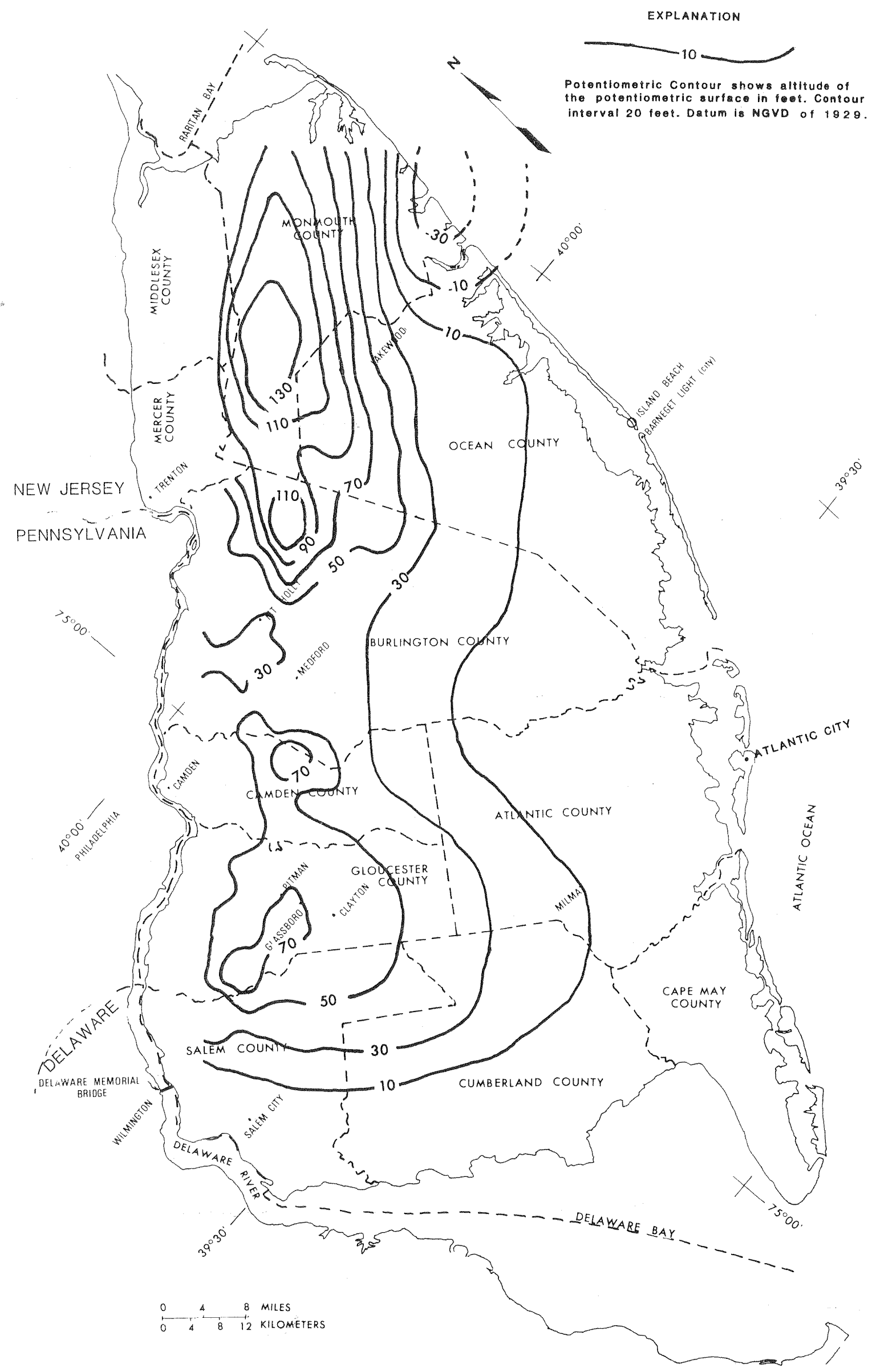

Figure 10.--Composite potentiometric surface of the Englishtown and Wenonah-Mount Laurel aquifers, 1959 (modified from Nemickas, 1976, figure 8 and Nichols, 1977, figure 15). 


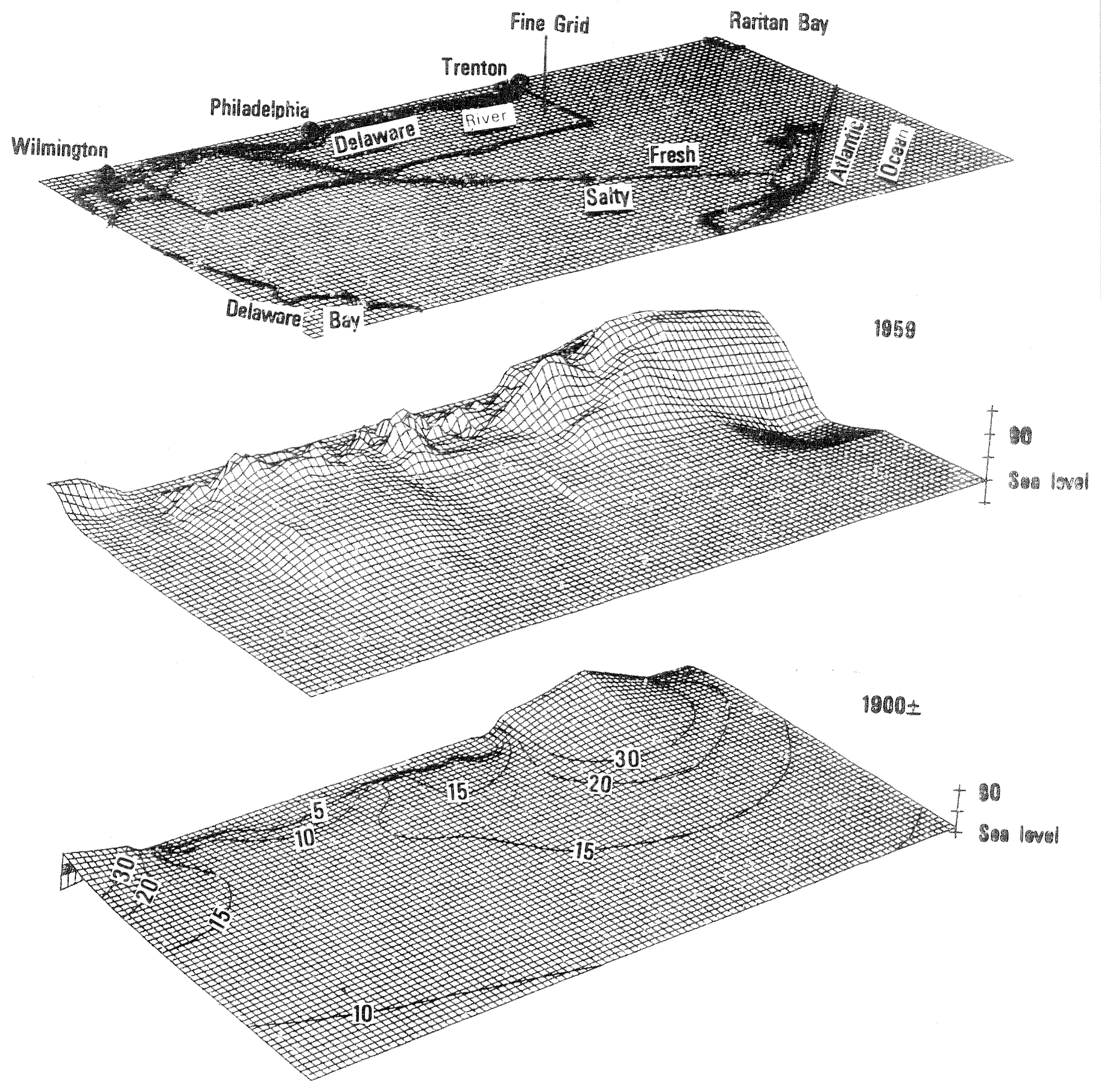

Figure 11.--Perspective view of the composite potentiometric surface (1959) over the confining layer and the computed steadystate (1900 \pm ) potentiometric surface of the PotomacRaritan-Magothy aquifer system. 
approximately 140 to 200 ft NGVD of 1929. An average head for each node in the depression for the period of 1959-73 was used for the simulations. Thus, with the exception of the averaging approach used in a few nodes that span the small depression, the 1959 surface as shown in figure 10 was used throughout the simulation period.

Recharge from precipitation in the outcrop area estimated by Barksdale and others (1958, p. 102) was approximately $1.0 \mathrm{ft} / \mathrm{yr}$ $(200 \mathrm{Mgal} / \mathrm{d})$, assuming that water falling on clay members would run off and be absorbed by more permeable aquifers. During model simulation, recharge to the outcrop, 0.1 to $1.0 \mathrm{ft} / \mathrm{yr}$, was used for test runs, and it was found that the recharge rate was not sensitive to model results, probably because of the proximity of constant heads along the Delaware River and the outcrop area. The final values used for recharge in the model were $0.35 \mathrm{ft} / \mathrm{yr}$ in the outcrop area southwest of Camden and $0.90 \mathrm{ft} / \mathrm{yr}$ northeast of Camden. Areas where the confining layer has been extended ( $f$ ig. 9) were modeled without recharge from precipitation.

\section{Ground-water Extractions, 1956-73}

Annual ground-water extractions for the 18-year period (1956-73) were collected for the entire aquifer system within the Coastal Plain of New Jersey. Most of the extraction data were obtained as metered monthly totals from files maintained by the New Jersey Department of Environmental Protection (NJDEP). In some instances where breakdowns by well or aquifer were not available, estimates were made on the bases of interviews with users. Extraction data in the adjacent areas outside of New Jersey (Philadelphia, Pa. and New Castle County, Del.) were obtained from Greenman and others (1961, p. 84-92), Sundstrom and Pickett (1971, p. 56 and 73), and from estimates made on the basis of interviews with users. In New Jersey, about 90 percent of the production wells are metered and reported to NJDEP quarterly. Properly installed and maintained flowmeters may have an accuracy within \pm 2 percent. However, because of wear, most meters may underregister somewhat. Thus, the reported extractions from old installations may be lower than actual. Other factors affecting reliability of extractions may include misreporting, estimation errors by users and the author, particularly for the earlier years of the simulation period, and errors occurring during at least five data transfer steps from the meter reading to computer storage by the U.S. Geological Survey. Because of these potential errors, a great deal of care was exercised in the collection and compilation of pumping data. Cross-checks, examination for inconsistencies, retracing numerous well-numbering changes, locating "grandfather" welis and diversion records were all carried out or resolved on a well-by-well, user-by-user basis in order to minimize errors. The accuracy of nearly all well locations was field checked.

Ground-water extraction data were manually processed and all manipulations, such as conversion of monthly totals to annual 
averages and the locating of all pumping wells in the proper elements of the model for the correct year, were done by a separate computer program and stored on disk for direct access by the model. To demonstrate how extractions were assigned on a nodal basis, a model element row 33, column 60 (33,60) is used as an example ( $f i g .6)$. Utilizing the dimensions of the model grid, the angle of rotation of the grid counterclockwise 38 degrees from east-west and converted and rotated $x$, y coordinates derived from latitude-longitude of well locations, the program determined that five pumping wells were located within that particular element in 1968. The sum of the pumping rates $\left(5.2 \mathrm{ft}^{3} / \mathrm{s}\right)$ was computed in 1968 for that node. The procedure was repeated for all wells and nodes for each of the 18 years until a complete master file was created for direct input to the model. Using this procedure, a potential error of determining rates and locating pumping nodes can be eliminated. Estimated overall accuracy of pumping rates used in the model within New Jersey would be approximately 80 to 90 percent.

Extraction rates from the Potomac-Raritan-Magothy aquifer system have risen almost continuously during the period 1956-73 (table 4). For the entire Coastal Plain of New Jersey, extraction rates increased from about $182 \mathrm{ft}^{3} / \mathrm{s}$ in 1956 to about $336 \mathrm{ft}^{3} / \mathrm{s}$ in 1973. Rates during the same period in the fine-grid area covering parts of Burlington, Camden, Gloucester, and Salem Counties increased from about $117 \mathrm{ft}^{3} / \mathrm{s}$ to about $224 \mathrm{ft}^{3} / \mathrm{s}$.

Figure 12 shows, in perspective, the distribution of extractions for the years 1956, 1965, and 1973. The two most prominent peaks are pumping centers in Camden City copposite Philadelphia) and near Raritan Bay in Middlesex County. For scale, the spike-like peak near Philadelphia represents a pumping rate of about $25 \mathrm{ft}^{2} / \mathrm{s}$ in 1973; rates of less than $1 \mathrm{ft}^{2} / \mathrm{s}$ are generally not visible. During the 18-year period, there had been a noticeable addition of pumping centers in the downdip direction towards the salty ground water. Three small pumping centers lined up in a north-trending row in the transition zone, south of Camden City, are located at Clayton, Glassboro, and Pitman ( $f i g .2$ ).

\section{PARAMETER ADJUSTMENT AND ACCEPTANCE OF THE MODEL}

Historical responses of the aquifer system to past stresses must be reasonably reproduced by the simulations in order to produce an acceptable model. Simulations were started in 1956 because drilling activity was sharply increased in the mid-1950's. More data points would be available over a relatively short period from which a starting head distribution could be constructed (fig. 13). Also, pumping records prior to 1956 were difficult or impossible to obtain. During a 6-week period in November-December in 1973, heads were measured at available wells after a period of shutdown. The resulting potentiometric surface observed in 1973 is shown in figure 14. Perspective potentiometric surfaces are shown in figure 15. The potentiometric surfaces were constructed on the basis of head measurements from wells that are screened at 
Table 4.--Annual extraction rates, 1956-73*

\begin{tabular}{|c|c|c|c|}
\hline Year & $\begin{array}{l}\text { Entire model area } \\
\qquad(\mathrm{ft} / \mathrm{s})\end{array}$ & $\begin{array}{c}\text { Fine-grid area } \\
\left(f t^{3} / s\right)\end{array}$ & $\begin{array}{l}\text { Total number } \\
\text { of nodes with } \\
\text { pumping wells** }\end{array}$ \\
\hline 1956 & 182.0 & 116.8 & 172 \\
\hline 1957 & 200.3 & 128.1 & 181 \\
\hline 1958 & 194.7 & 123.3 & 186 \\
\hline 1959 & 209.4 & 131.2 & 191 \\
\hline 1960 & 212.6 & 134.6 & 203 \\
\hline 1961 & 231.1 & 149.0 & 208 \\
\hline 1962 & 239.5 & 156.1 & 222 \\
\hline 1963 & 256.5 & 167.0 & 225 \\
\hline 1964 & 271.9 & 176.3 & 228 \\
\hline 1965 & 277.8 & 183.8 & 238 \\
\hline 1966 & 287.6 & 188.2 & 258 \\
\hline 1967 & 283.9 & 186.6 & 258 \\
\hline 1968 & 307.8 & 201.0 & 262 \\
\hline 1969 & 313.7 & 201.4 & 279 \\
\hline 1970 & 330.8 & 214.2 & 273 \\
\hline 1971 & 331.9 & 216.9 & 276 \\
\hline 1972 & 326.9 & 215.3 & 273 \\
\hline 1973 & 336.3 & 223.5 & 270 \\
\hline
\end{tabular}

* Includes 8 to $14 \mathrm{ft}^{3} / \mathrm{s}$ in Philadelphia area, and about $17 \mathrm{ft}^{3} / \mathrm{s}$ in New Castle County, Delaware.

* Exact well count is not available but is estimated to range from more than 400 wells in 1956, to more than 600 wells in 1973. 


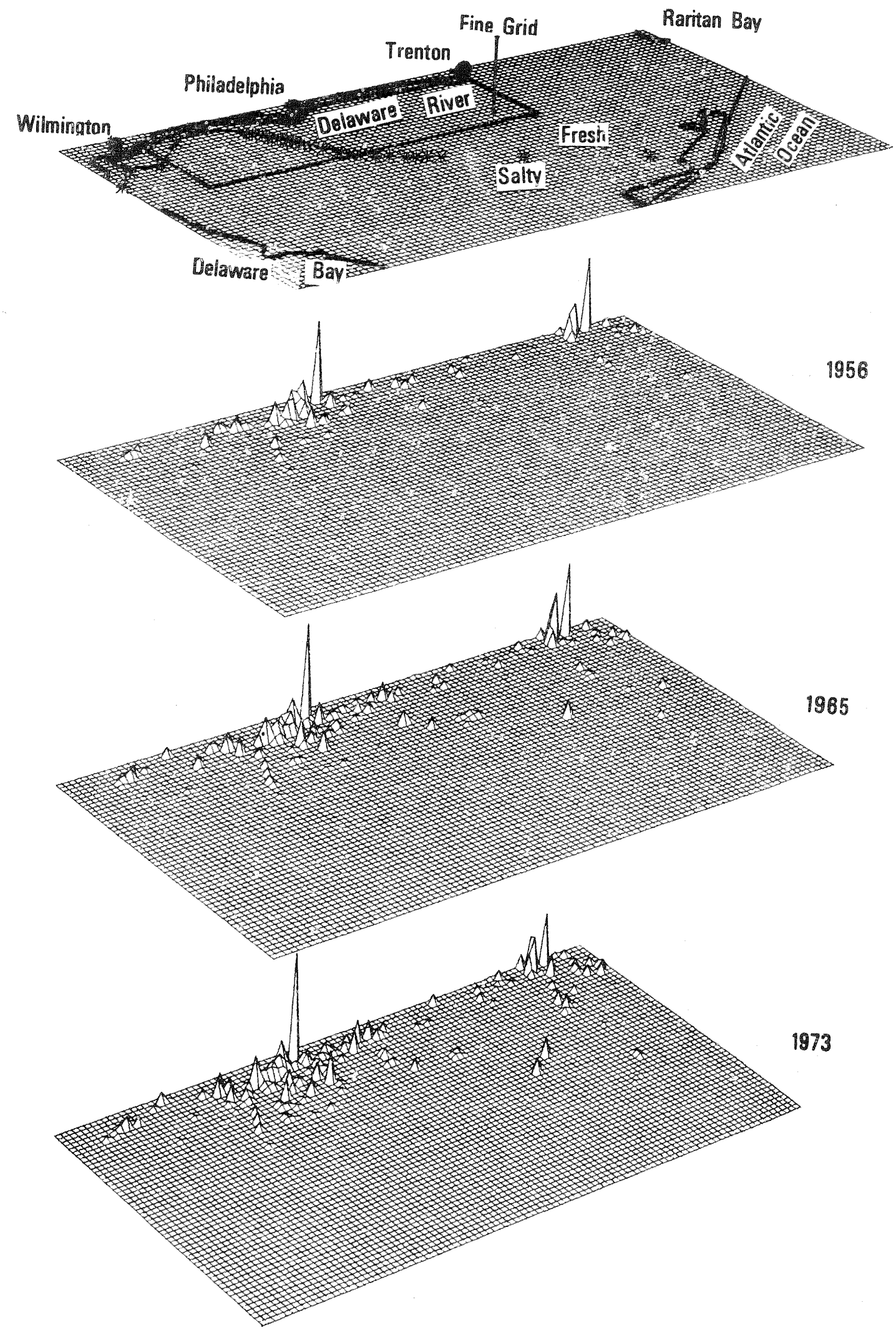

Figure 12.--Perspective view of the distribution of ground-water extractions from the Potomac-Raritan-Magothy aquifer system in 1956,1965 , and 1973. 


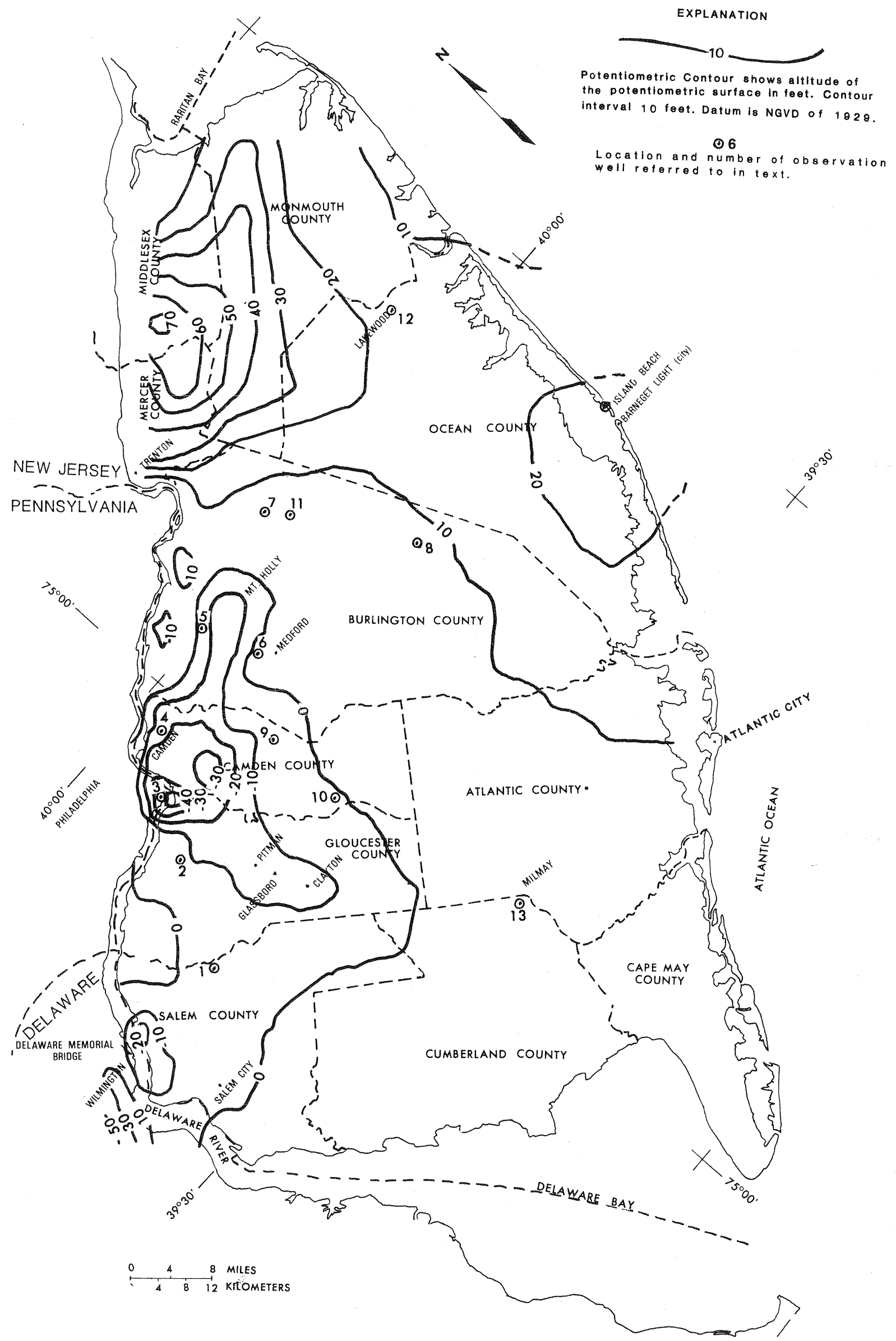

Figure 13.--Potentiometric surface of the Potomac-Raritan-Magothy aquifer system, 1956. 


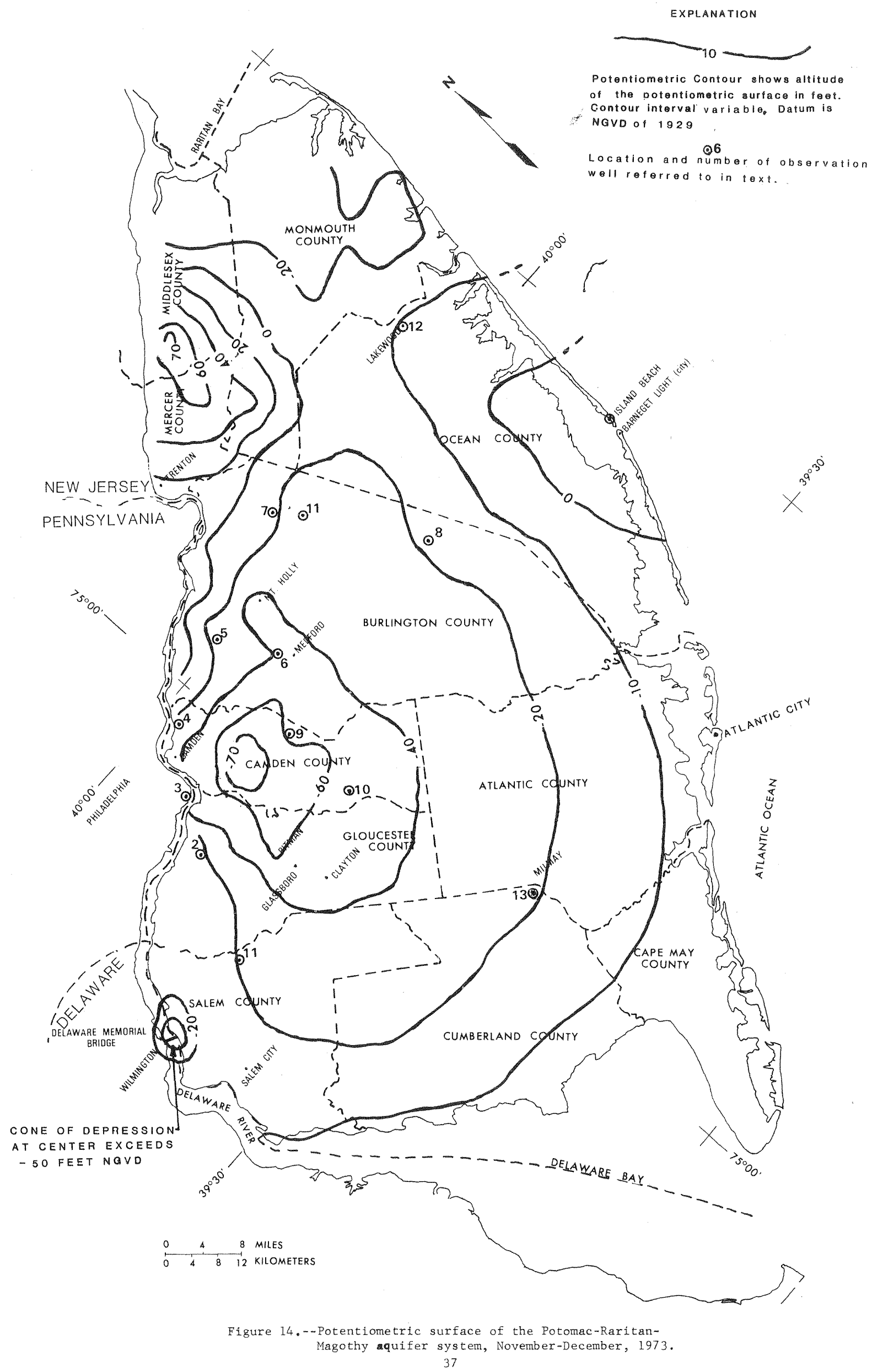




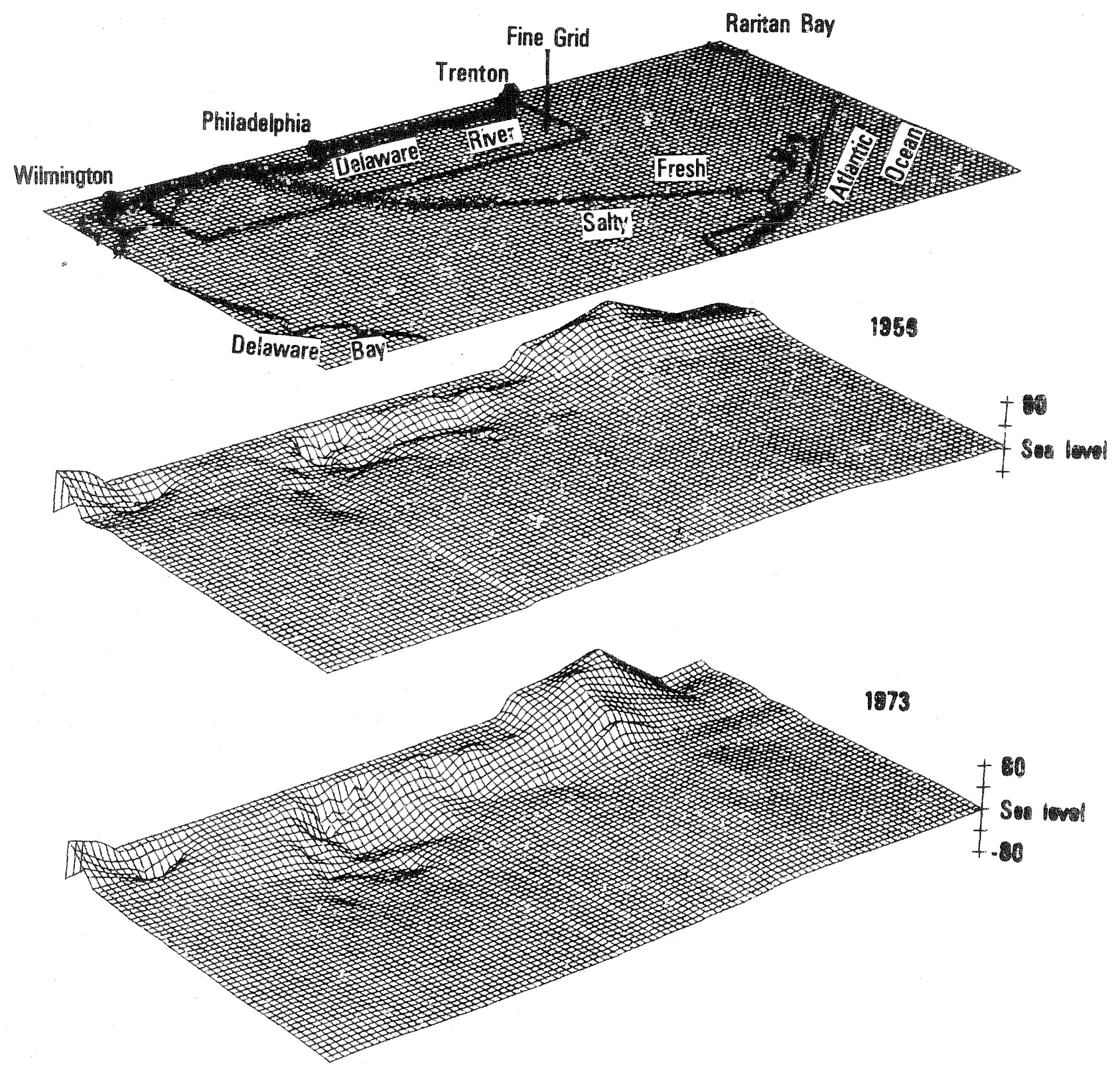

Figure 15.--Perspective view of the potentiometric surfaces of the PotomacRaritan-Magothy aquifer system observed in 1956 and 1973, respectively. 
various depths. At locations where head differences with depth existed (usually less than $10 \mathrm{ft}$ ), the head of lowest altitude was used for control.

If the parameters and boundary conditions used in the model are able to approximately simulate the aquifer system, then by using the 1956 potentiometric surface as the initial starting heads, it should be possible to reproduce the 1973 observed potentiometric surface, in addition to well hydrographs observed during the period of 1956 through 1973. However, high degrees of uncertainty usually involve parameter and boundary determinations; therefore, it is necessary to run test simulations for adjusting parameters and boundaries of the model in an effort to reproduce hydrograph trends and the observed 1973 potentiometric surface. During the test simulation, some parameters were fixed, such as grid size and physical hydrologic boundaries, pumping rates, and starting heads. Others were adjusted, such as transmissivity, vertical hydraulic conductivity of the confining layer, storage coefficient, and recharge in the outcrop area.

\section{Matching of Well Hydrographs and 1973 Potentiometric Surface}

Parameters were adjusted during test simulations by comparison of the model results with the observed 1973 potentiometric surface (figs. 14 and 16) and 10 hydrographs (figs. 17,18 , and 19).

The observed hydrographs were constructed on the basis of the maximum recovery during each spring. Nearly all the observation wells are far enough away from pumping wells that continuous recorders show only gentle, somewhat sinosoidal fluctuations caused by increased pumping during the summer, with amplitudes ranging from about 2 to $8 \mathrm{ft}$. It should be noted that wells 6 , 9, and 10 are each within a cluster of other observation wells drilled at the same location, but are screened at different depths in the aquifer system. At each site, the trends measured at different depths are essentially identical, although the head altitude may be slightly different.

The results of modifying any parameter in the model were quickly noticeable in the computed trends. The hydrographs represent wells widely distributed in the study area and were used in conjunction with matching of the 1973 potentiometric surface produced at the end of each run. The criteria used in trying to achieve a best fit was that the difference between the computed and observed potentiometric surfaces and well hydrographs should be within $\pm 8 \mathrm{ft}$. All adjustable parameters were kept within the range that is considered reasonable and are shown below. 


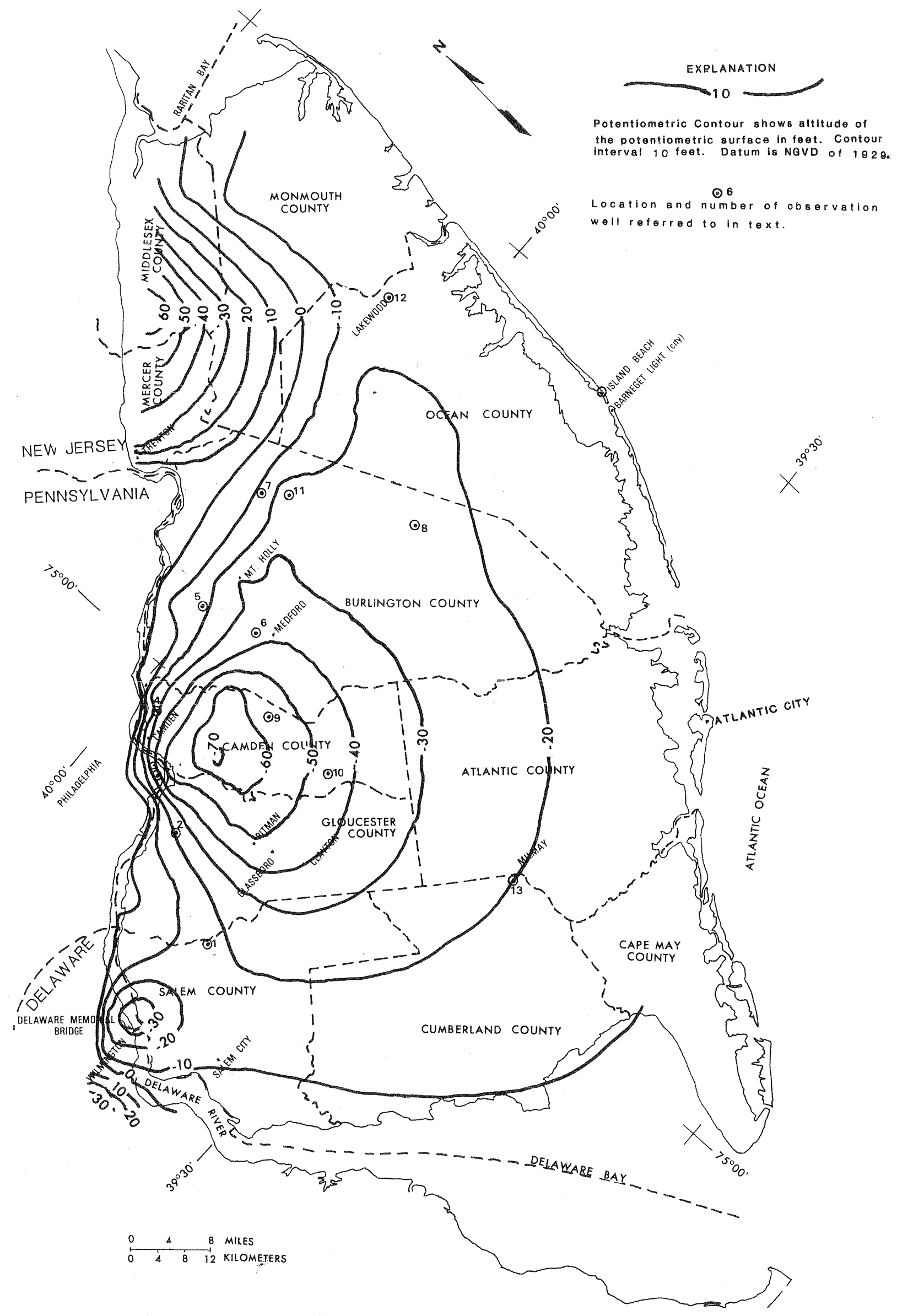

Figure 16.--Potentiometric surface of the Potomac-RaritanMagothy quifer system, December 1973, computed by model. 


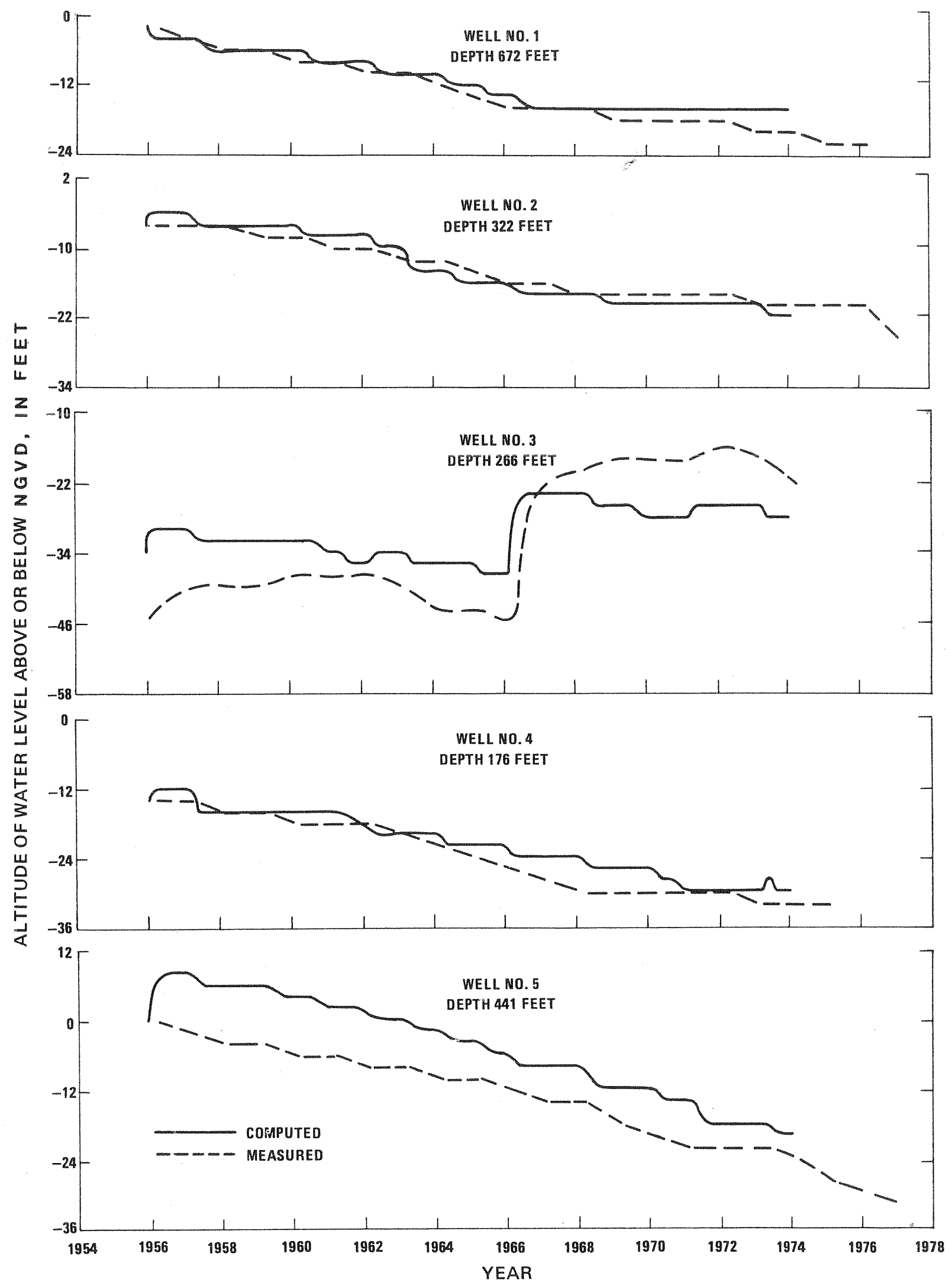

Figure 17.--Observed and computed hydrographs of wells parallel to or located within the outcrop area along the northwestern side of the cone of depression. 


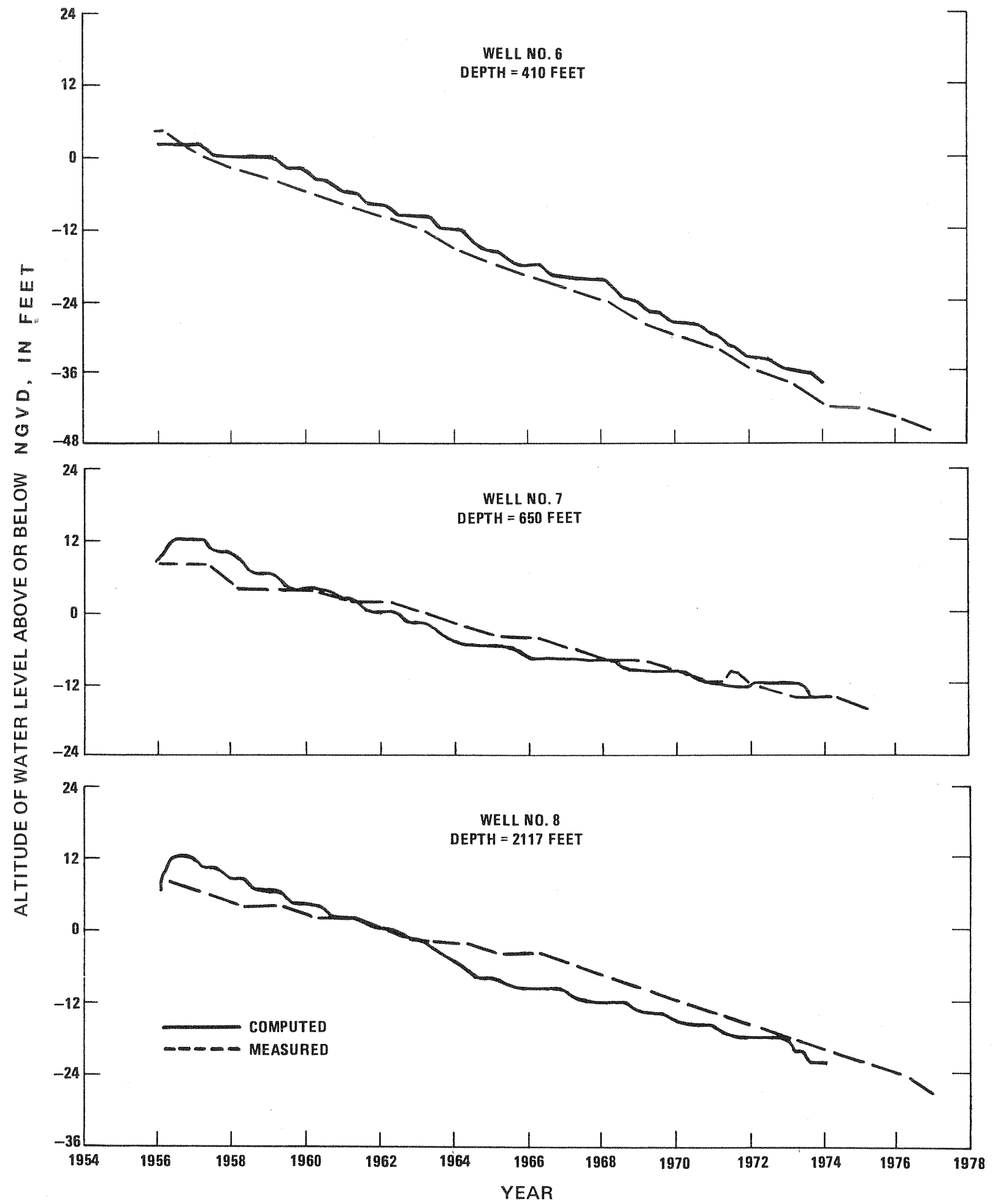

Figure 18,--Observed and computed hydrographs of wells located in the northwestern part of the cone of depression. 


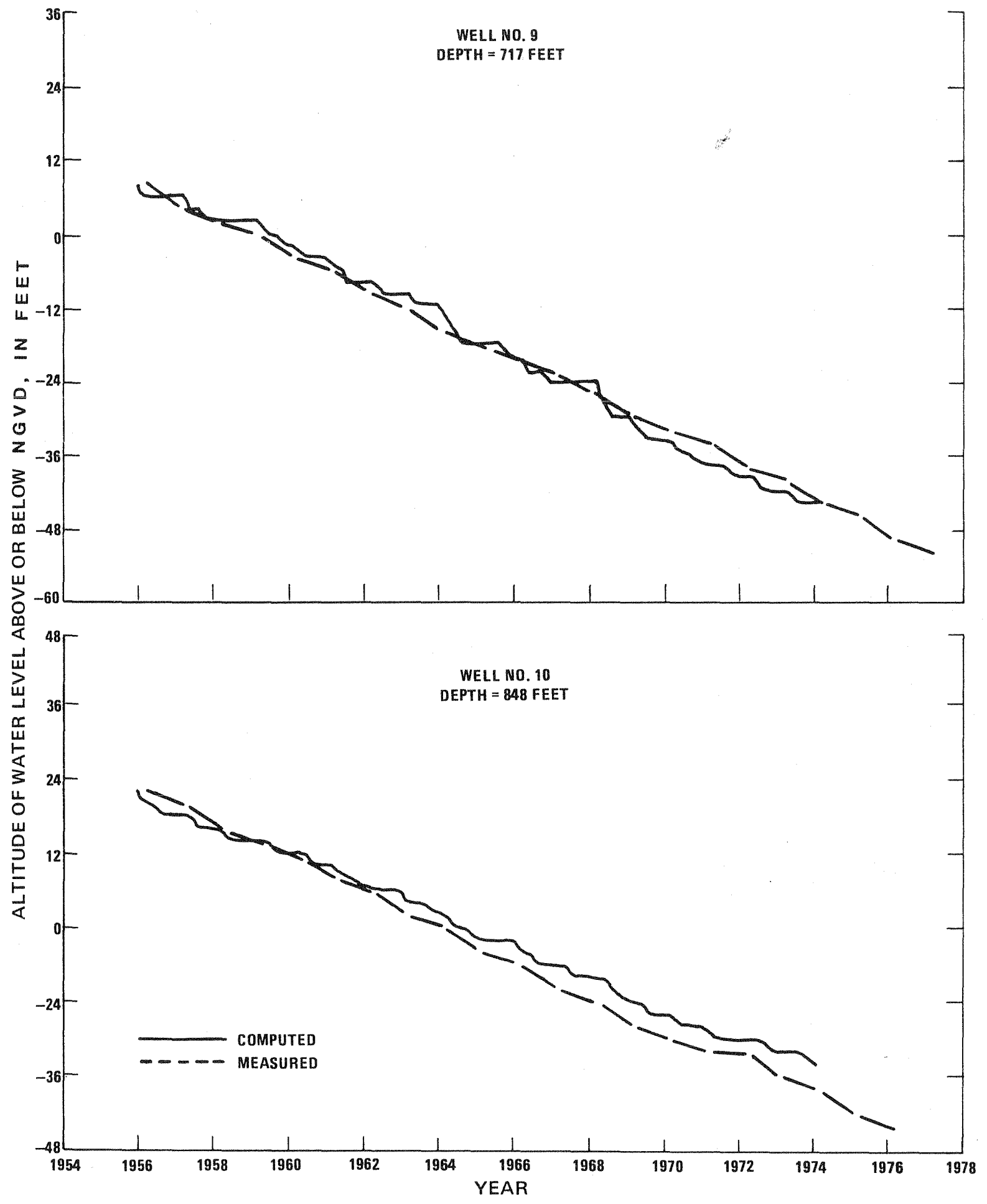

Figure 19.--Observed and computed hydrographs of wells located in the southern part of the cone of depression. 
Parameter

Transmissivity

$f t^{2} d a y$

Storage coefficient

(dimensionless)

Vertical hydraulic conductivity of the confining layer ( $\mathrm{ft} / \mathrm{s}$ )

Recharge due to precipitation in outcrop ( $\mathrm{ft} / \mathrm{yr}$ )
Assumed limits

$$
5,000 \text { to } 40,000
$$$$
1 \times 10^{-5} \text { to } 0.20
$$

$1 \times 10^{-11}$ to $9 \times 10^{-9}$

0.1 to 1.7
Range used in model

6,000 to

35,000

$8 \times 10^{-5}$ to

$8 \times 10^{-3}$

$1 \times 10^{-11}$ to

$2 \times 10^{-8}$

0.35 to 0.90

It is also reasonable to assume that parameters probably vary with aquifer geometry. For example, near the outcrop area the storage coefficient for the aquifer system and vertical conductivity of the confining layer probably would be higher. Recharge also probably increases with elevation. Flat swampy areas near sea level, where the aquifer system is fully saturated, probably would not accept much recharge.

The observed 1973 potentiometric surface was matched reasonably well by the model generated surface as shown in figures 14 and 16. The greatest discrepancies between the computed and the observed 1973 potentiometric heads in and near the fine-grid area occurred in areas near Mount Holly (northeast of well 6), and near the Delaware Memorial Bridge (west of well 1). A better fit could not be obtained in the Mount Holly area without forcing some of the parameters out of the reasonable range. Computer simulations also failed to accurately duplicate a small cone of depression near the Delaware Memorial Bridge; however, this may be due to poor data definition including water levels and pumping rates in Delaware.

The match between computed and observed well hydrographs is shown in figures 17, 18, and 19. The large head recovery at the U.S. Navy base well (well 3) was caused by shutdown of nearly all wells at the Navy base in March 1966. A long history of increasingly contaminated ground water on the Philadelphia side of the Delaware River contributed to this shutdown. The Navy base had previously accounted for most of the extractions in the Philadelphia area. 
The model was run without pumping wells and allowed to reach equilibrium or steady state after obtaining an acceptable match of the observed 1973 potentiometric surface and the hydrograph trends. The steady-state head solution ( $f i g .20$ and fig 11, lower view) was controlled by constant head elevations of recharge and discharge areas, transmissivity, the amount of recharge specified in the outcrop, the head over the confining layer (fig. 11, middle view), and the vertical hydraulic conductivity of the confining layer. If the model was a perfect mimic of the physical aquifer system, the steady-state head distribution would precisely reproduce the prepumping head distribution. The year of 1900 was considered to represent the predevelopment conditions, but few weIls would have been available for head measurement at that time. Barksdale and others (1958, p. 112-113) prepared a map showing the general head distribution (also included on fig. 20) based upon the earliest known well measurements, some spanning a period of about 50 years.

The comparison between the model produced steady-state

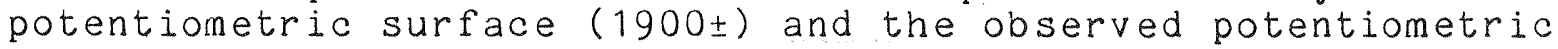
surface indicates a good agreement between the two surfaces (fig. 20). A theoretical flow pattern for nonpumping conditions was also prepared by Barksdale and others (1958, p. 109-111) and is reproduced here (fig. 21) for comparison with the contoured perspective view of the model generated steady-state solution (fig. 11).

\section{Sensitivity of Parameter Adjustment}

Sensitivity tests have been made by modifying modelwide, one parameter at a time and observing the effects. Figure 22

illustrates the effect of parameter changes on water-level trends at a deep observation well near the center of the fine-grid area. Increase or decrease of transmissivity by 20 percent has about doubled the effect on drawdown (after 18 years) that an equivalent change in confining layer vertical hydraulic conductivity causes. Departures from the observed trend caused by changing the two parameters gradually increase with time; however, the change was almost negligible during the first 6 years.

Figure 22 also shows the effect of reducing total steady leakage through the confining layer from $69 \mathrm{ft}^{3} / \mathrm{s}$ to $0.2 \mathrm{ft}^{3} / \mathrm{s}$ by setting the vertical hydraulic conductivity everywhere to the smallest value, $1 \times 10^{-11} \mathrm{ft} / \mathrm{s}$. This change had a major effect on heads. Because the amount of leakage was virtually eliminated as a source of recharge, only precipitation on the outcrop and constant heads along the Delaware River remained as major sources of recharge. Thus, induced flow from the river increased from 95 to $162 \mathrm{ft} 3 / \mathrm{s}$ because of the loss in head and the increase in hydraulic gradient in the aquifer system. 


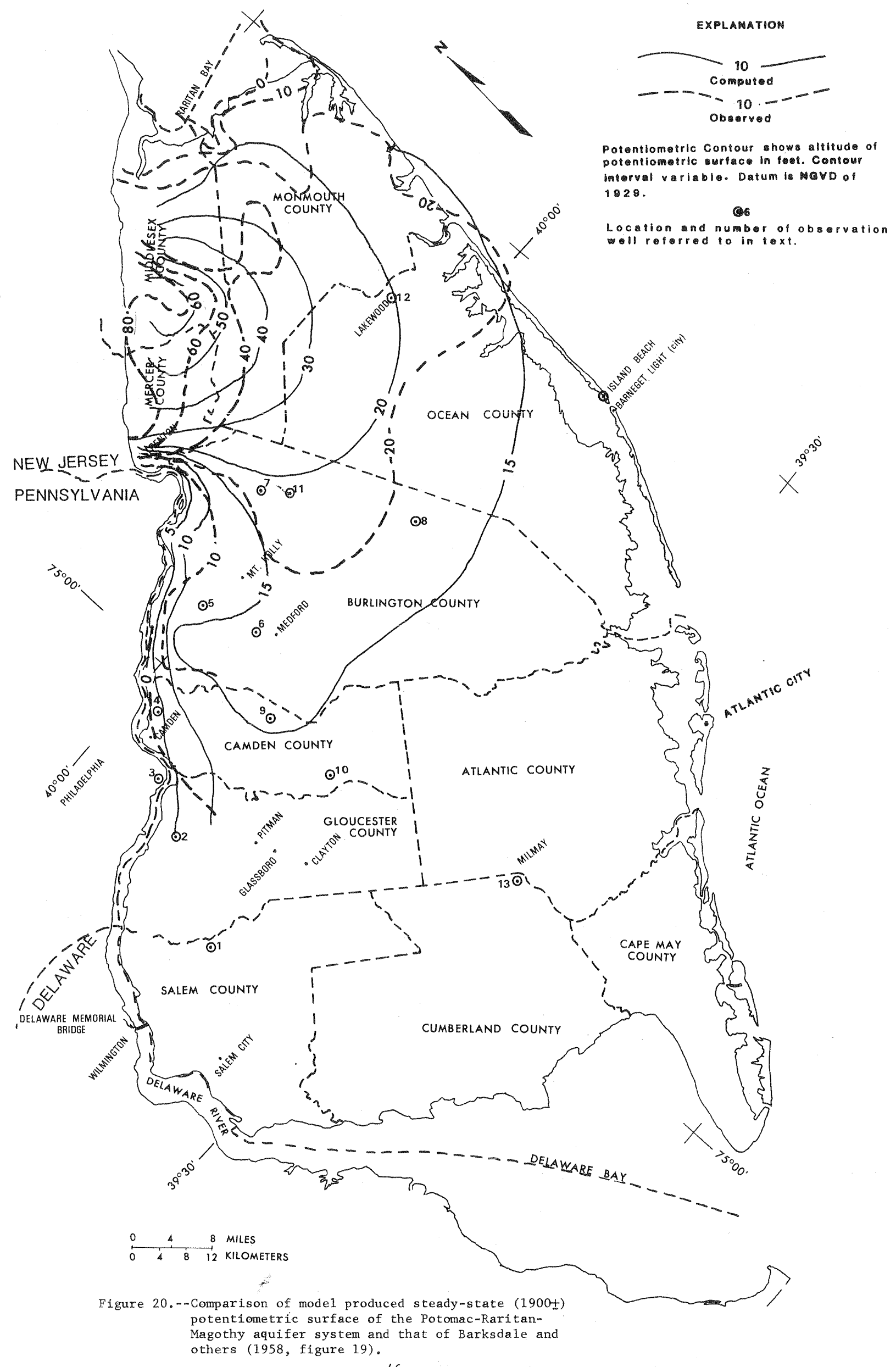


Aquifer system outcrop

Potontiometric contours (theoretical)

Flow lines

High-level intake area

Int rfaco botwo n froshwator and salty wator

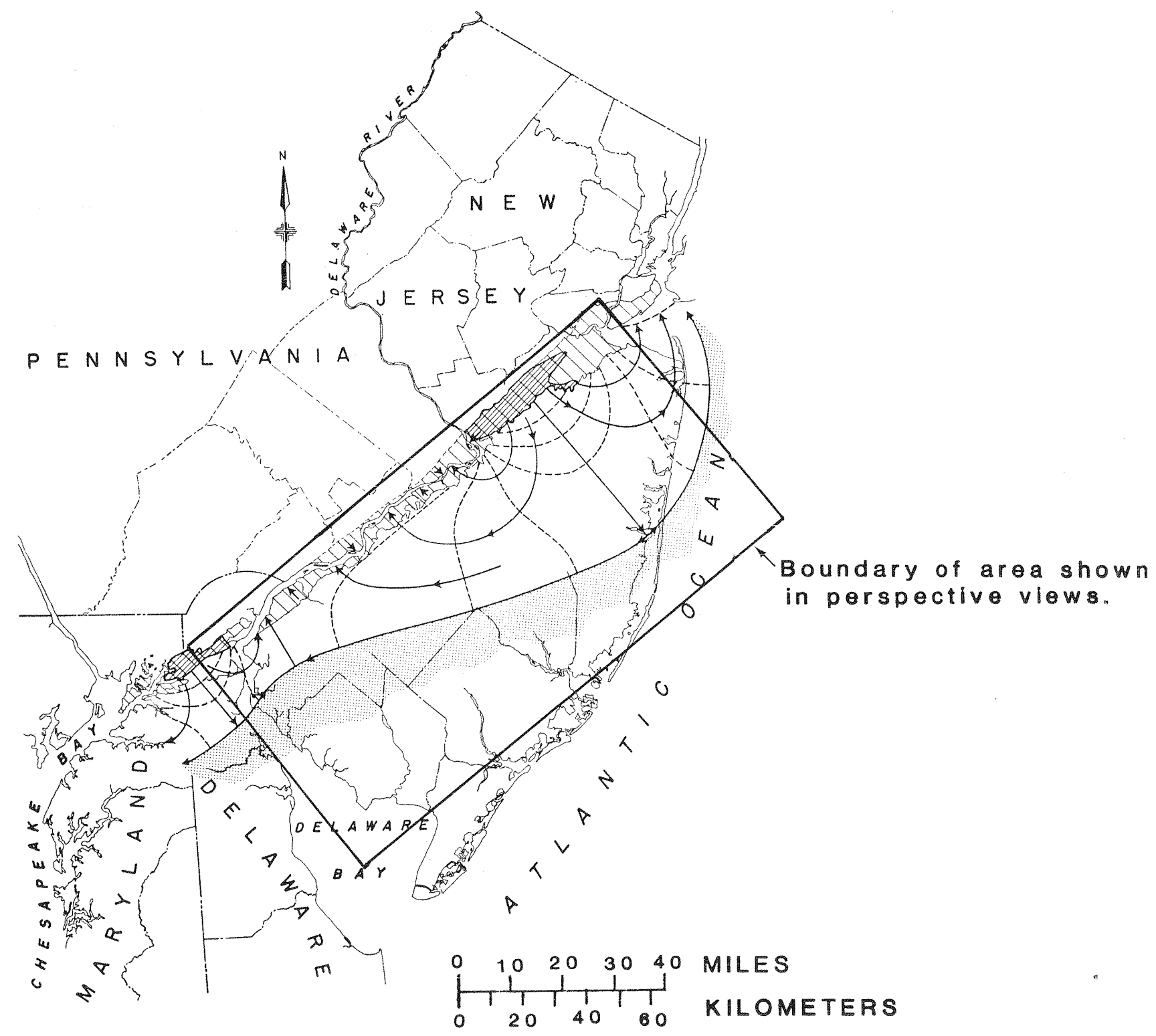

Figure 21.--Theoretical flow pattern and location of the interface between freshwater and salty water in the PotomacRaritan-Magothy aquifer system before any pumping of ground water (after Barksdale and others, 1958, figure 18). 


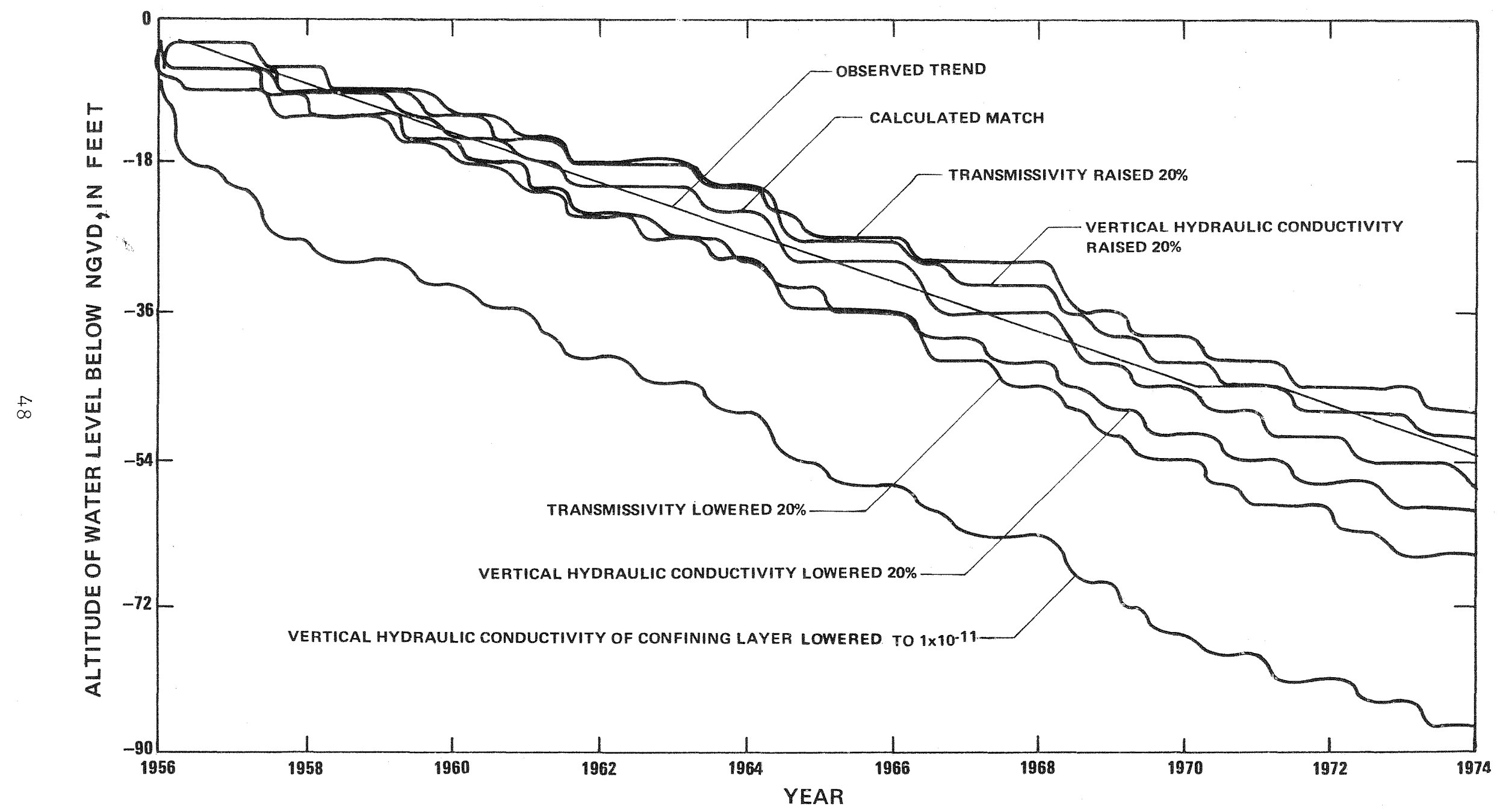

Figure 22.--Effect of model-wide changes in parameters at observation well 9. 
Three other sensitivity tests were made which resulted in head changes of less than $1 \mathrm{ft}$ at the end of the 18-year period. The 1956 starting head distribution in the aquifer system was raised 20 percent; the seaward no-flow boundary of the model was changed to a constant head boundary; and the seaward no-flow boundary was moved $76 \mathrm{mi}$ closer to the New Jersey coastline, thereby placing the boundary about $30 \mathrm{mi}$ offshore. The effect of raising the starting heads quickly dissipated (within 2 years) probably because the aquifer system is so close to steady state at the end of each pumping period. This test demonstrated that the model is relatively insensitive to errors in the initial head distribution. In addition, the failure of the boundary tests to affect head distribution suggests that errors in defining the seaward boundary more accurately are not significant.

\section{MODEL APPLICATION IN WATER MANAGEMENT \\ Projected Changes in Potentiometric Surface, 1974-2000, On the basis of 1973 Well Distribution}

The model has been used to simulate water level response to the year 2000 under several sets of scheduled pumping rates. The projections described below were made on the assumption that location of pumping sites will remain the same as those observed in 1973. Any additional demands for ground water would be met by increasing pumping rates of wells which were pumping in 1973, and by adding new wells in the same model elements that had pumping wells in 1973. The first projection assumes that ground-water extractions are held constant at the 1973 level (zero growth); the second projection assumes compounded annual growth in extraction rates of 1.7 percent and 3.0 percent; and a third projection assumes a 3.0 percent annual growth rate, but with a freshwater head barrier activated and superposed on the pumping stress starting in 1984. The head barrier was placed along the updip edge of the salty water body.

On the basis of population projections (1980 to 2020) in eight coastal-plain counties by the State of New Jersey, Department of Labor and Industry (1975, p. 4 and 6), two pumping growth rates of 1.7 and 3.0 percent were selected to represent the most likely growth rate to be expected (fig. 23).

Other assumptions involved in the following projections are those inherent in the construction of the simulation model. These include the assumption that the head over the confining layer and recharge in the outcrop area do not change with time. However, in certain areas, some reduction in head over the confining layer will likely take place, thus reducing the driving force for steady leakage. Conversely, some increase in recharge rates in the outcrop area could be expected as more space is made available in the aquifer system by head reduction. The actual impact of these two assumptions in any projection is probably not great, however, because most large changes in head over the confining layer are likely to occur in coastal areas remote from the fine-grid area as 


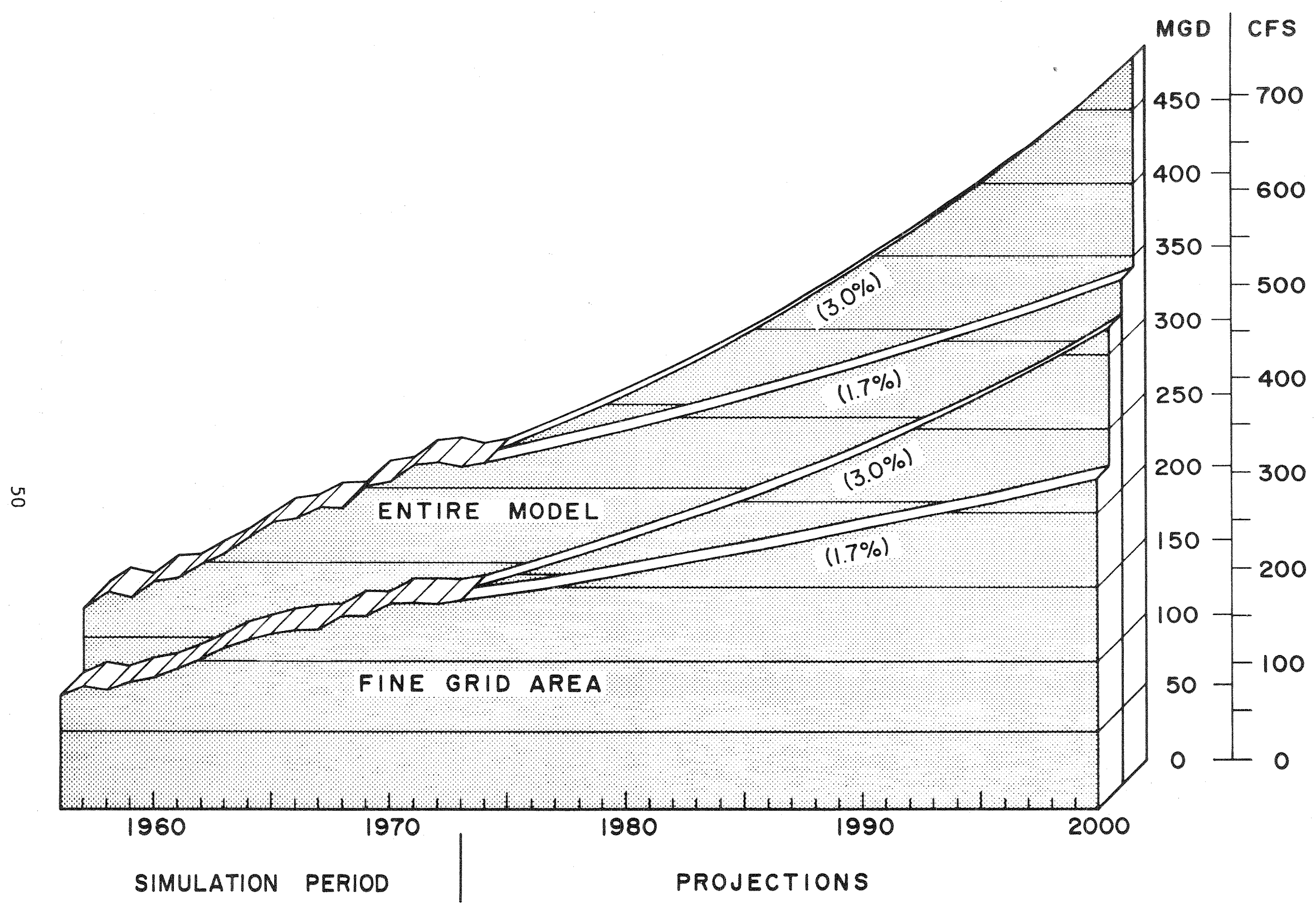

Figure 23.--Actal and projected ground-water extractions from the Potonc-Rinitan-Mathy aquifer system, 1956-2000. 
they have in the past. Also, most of the outcrop area of the aquifer system near the fine grid contains major rivers that are treated as constant heads, which tend to outweigh any changes in recharge from precipitation. Additionally, the assumption was made that there is no transient leakage from the Merchantville-Woodbury confining layer. This assumption becomes less valid as the cone of depression expands downdip.

\section{Extractions Held at Zero Growth Rate}

The first projected potentiometric head distribution for the year 2000 was simulated without increase in pumping rates after 1973. The predicted hydrograph trends (figs. 24, 25, and 26) show that head reduction in the aquifer system would cease within 2 years over a large portion of the study area. The predicted potentiometric surface for the year 2000 is nearly the same as the 1973 computed surface (fig. 16), except that the main cone of depression for the year 2000 is slightly shallower by several feet and slightly expanded. This projection suggests that a general reduction in extraction rates would reduce head loss which would in turn decrease recharge from constant head sources due to lower hydraulic gradients along the outcrop. Likewise, hydraulic gradients would flatten somewhat along the southeastern margin of the fine grid resulting in slightly less lateral inflow from that direction.

\section{Extractions Increasing at 1.7 Percent Per Year}

The second projected potentiometric head distribution for the year 2000 was made by allowing the 1973 pumping rates to increase at 1.7 percent per year. Most of the projected hydrograph trends (figs. 24, 25, and 26) show a reduced rate of head reduction after 1973. This simulation result indicates that the historical pumping growth rates probably were greater than 1.7 percent per year. The simulated potentiometric surface for the year 2000 (fig. 27) shows a well developed cone of depression with nearly the same shape as that computed for the year 1973 (fig. 16), but with heads in the confined portions of the aquifer system ranging from about 20 to $30 \mathrm{ft}$ lower than the heads in 1973. Hydraulic gradients within and perpendicular to boundaries of the transition zone north of Clayton ( $\mathrm{fig} .27$ ) would increase to about $4 \mathrm{ft} / \mathrm{mi}$ relative to that of 1973 and give ground-water velocities of about $55 \mathrm{ft} / \mathrm{yr}$. Hydraulic gradients beneath the Delaware River estuary, adjacent but parallel to the transition zone near well 2 , would reach $7 \mathrm{ft} / \mathrm{mi}$ and give ground-water velocities of about $420 \mathrm{ft} / \mathrm{yr}$.

A perspective view of the year 2000 potentiometric surface is included in figure 28. This view shows a large, well developed cone of depression with its steeper side roughly parallel to the Delaware River. Compared to the 1973 surface, hydraulic gradients for the year 2000 beneath the Delaware would be increased considerably. Induced recharge, as calculated by the model, from the Delaware River for the year 2000 would more than double in the fine-grid area. Steady leakage would account for about 27 percent 


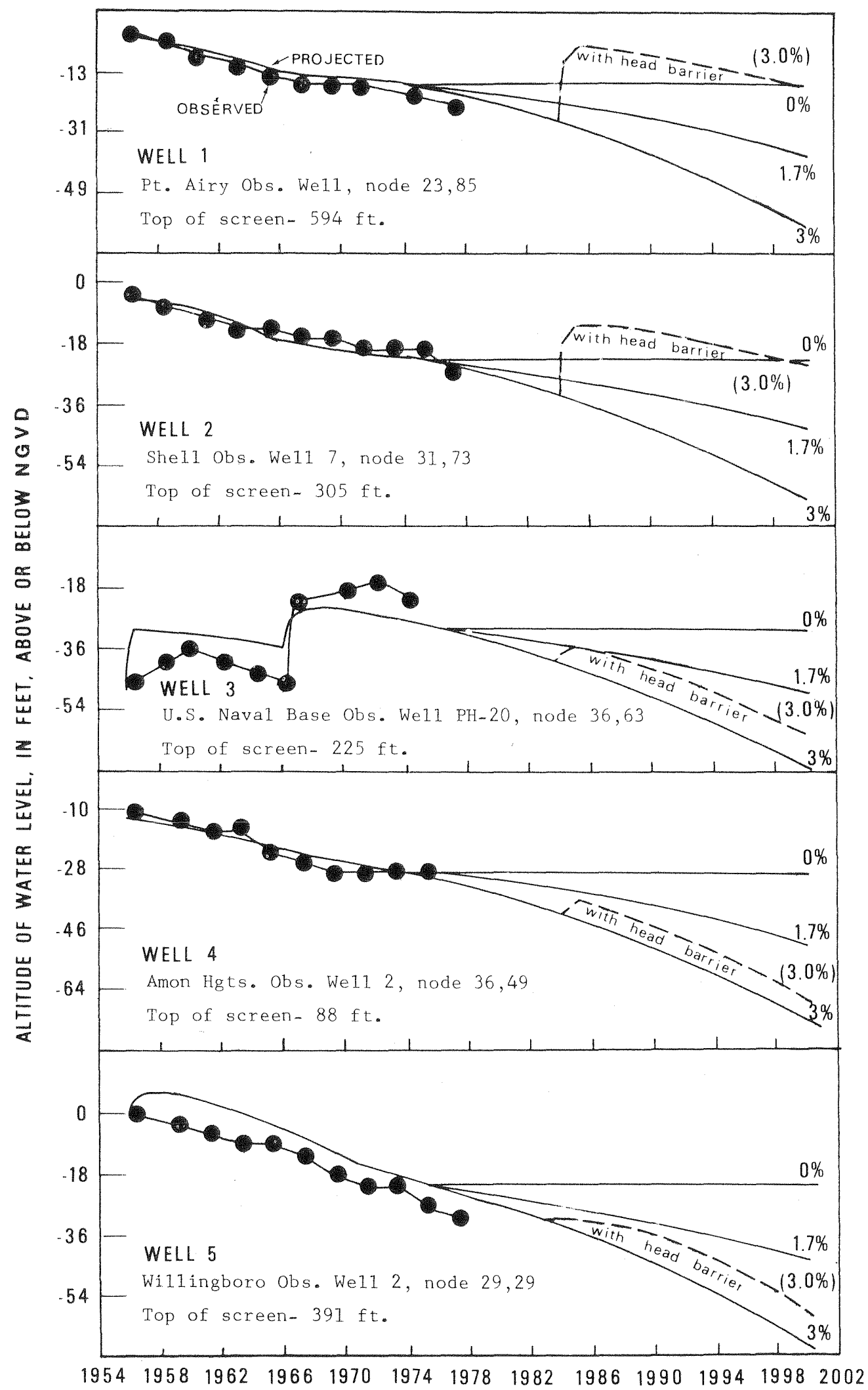

Figure 24.--Observed and projected hydrograph trends of wells 1 , $2,3,4$, and 5 (percentage indicates extraction growth rates). 


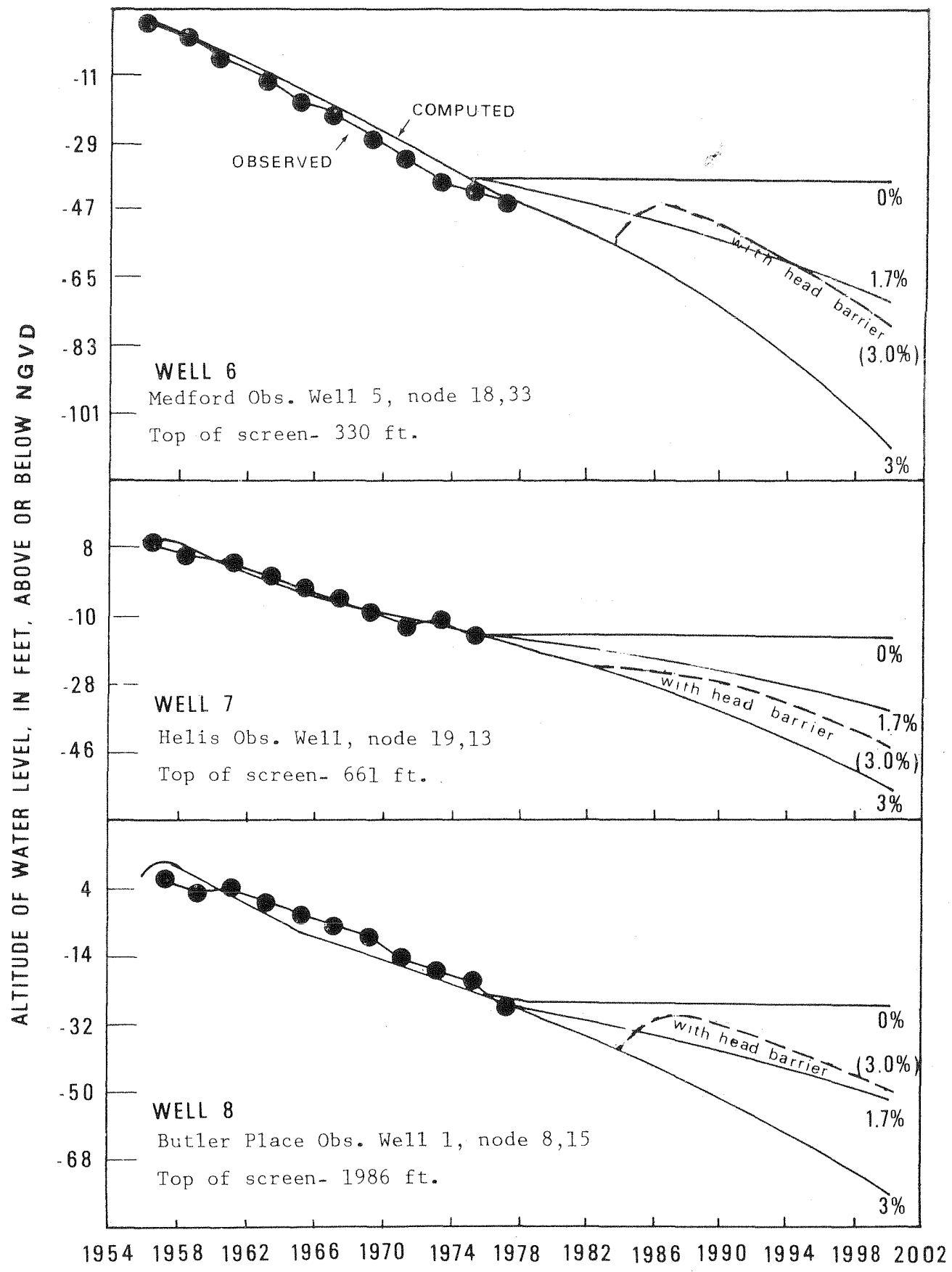

Figure 25.--Observed and projected hydrograph trends of wella 6 , 7 , and 8 (percentage indicates extraction growth rates). 


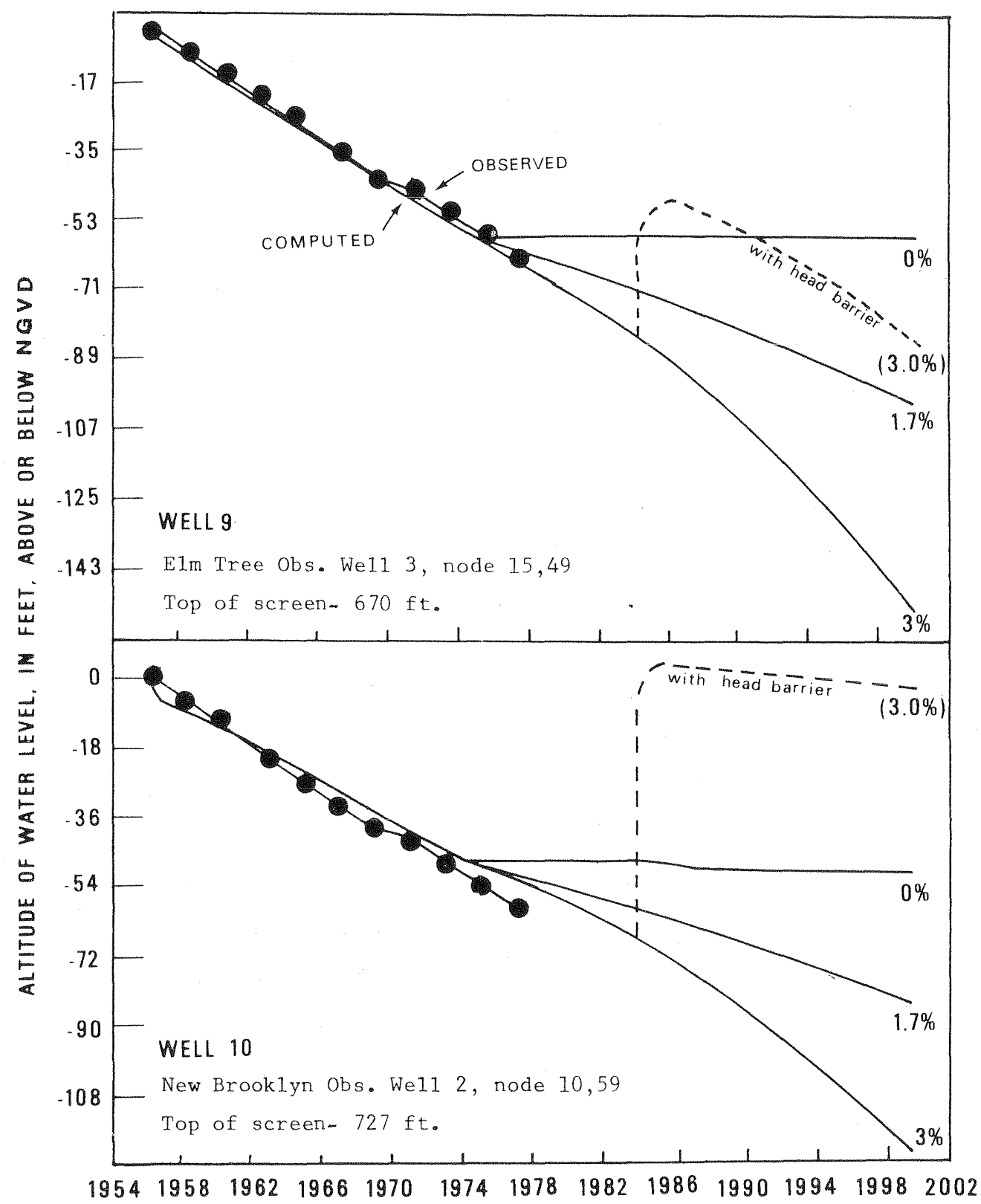

Figure 26.--Observed and projected hydrograph trends of wells 9 and 10 (percentage indicates extraction growth rates). 


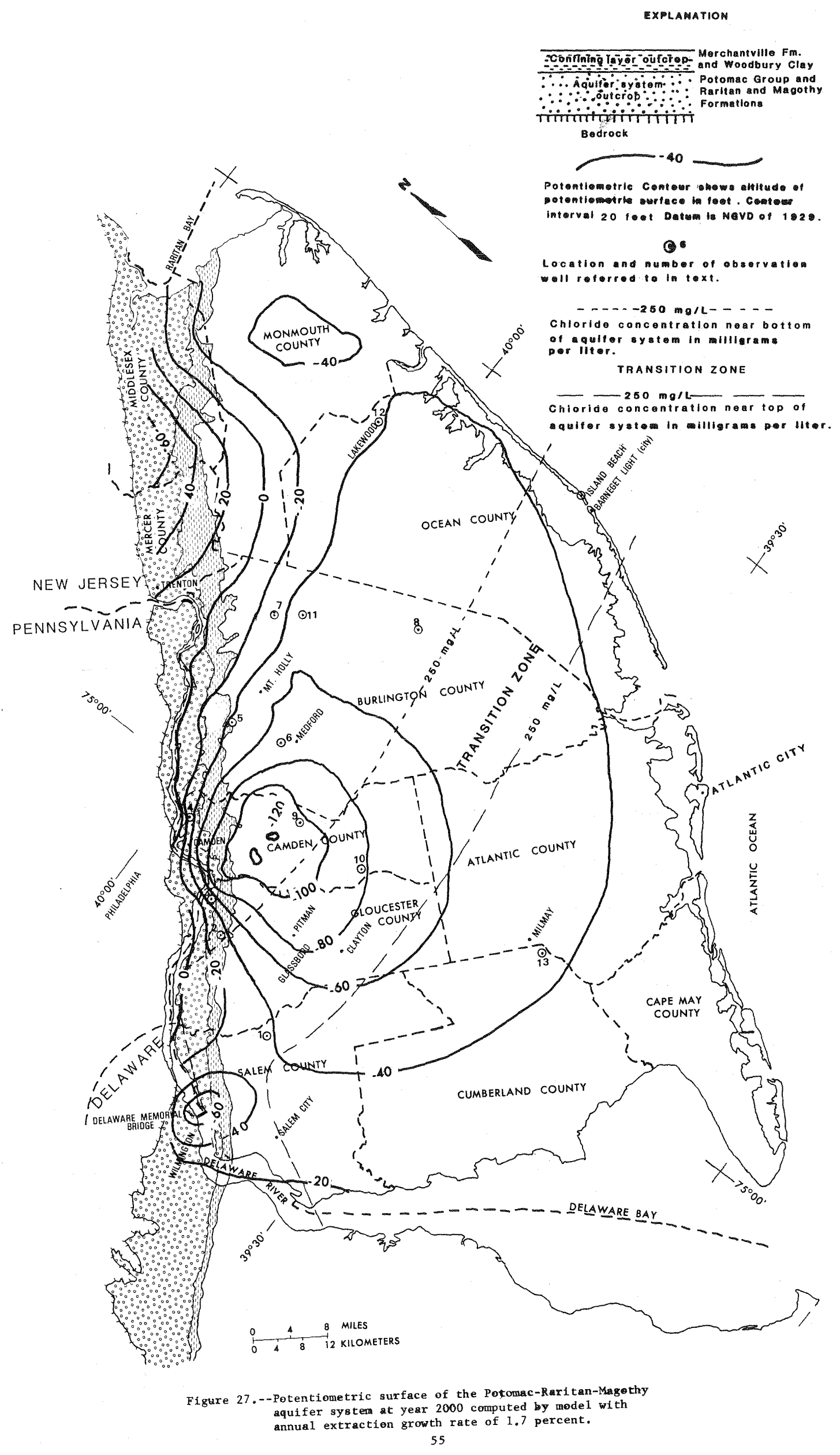




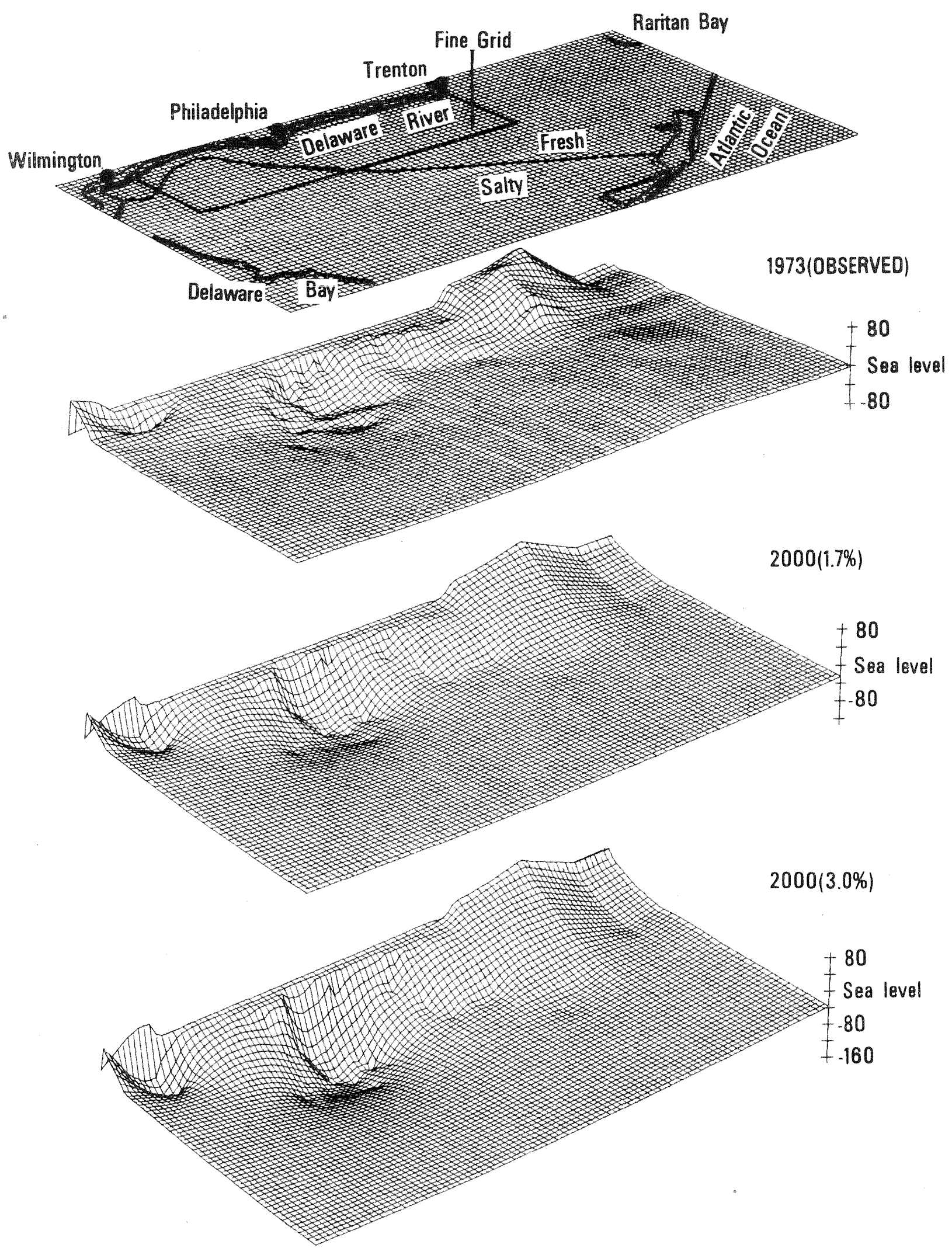

Figure 28.--Perspective potentiometric surfaces of the PotomacRaritan-Magothy aquifer system observed in 1973, and projected to year 2000 using annual extraction growth rates of 1.7 and 3.0 percent. 
(93 $\left.\mathrm{ft}^{3} / \mathrm{s}\right)$ of the total extracted.

Extractions Increasing at 3.0 Percent Per Year

A third projected potentionetric head distribution for the year 2000 was made by allowing the 1973 pumping rates to increase at 3.0 percent per year. Hydrograph trends after 1973 (figs. 24, 25, and 26) continue to follow those established during the sinulation period. The year 2000 potentiometric surface (fig. 29) shows an extremely large cone of depression with heads in confined parts of the aquifer system ranging from about 40 to 80 ft lower than the heads in 1973. Hydraulic gradients perpendicular to the boundary of the transition zone near Clayton would increase by the year 2000 to about $7 \mathrm{ft} / \mathrm{mi}$. Hydraulic gradients beneath the Delaware River toward well 2 would increase to about $11 \mathrm{ft} / \mathrm{mi}$.

A perspective view of the year 2000 potentionetric surface is included on figure 28 for comparison with that computed for the year 1973. Steepened gradients along the Delaware River would greatly increase the amount of induced recharge reaching wells in the fine-grid area to about 62 percent or $300 \mathrm{ft}^{3} / \mathrm{s}$ of the total extractions in the year 2000. Steady leakage through the confining layer would account for about 24 percent (116 $\left.\mathrm{ft}^{3} / \mathrm{s}\right)$.

\section{Estimating Amount of Artificial Recharge Required to Delay or Prevent Migration of Salty Ground Water}

A model run was made to explore the effects of an injected freshwater head barrier placed near the updip edge of the freshwater-saltwater transition zone. Inposition of such a head barrier would prevent migration of salty ground water into the large cone of depression (fig. 30). The model run was made by supposition on a 3 percent pumping growth rate in 1984, with 19 constant heads nodes, with head elevations maintained at $10 \mathrm{ft}$ above mean sea level along the updip edge of the fresh-saltwater transition zone. These 19 nodes extended $35 \mathrm{mi}$ across Gloucester, Camden, and Burlington Counties. Recharge rates average initially about $3 \mathrm{ft}^{3} / \mathrm{s}$ and increase to an average of about $5 \mathrm{ft}^{3} / \mathrm{s}$ for each node by the year 2000 and are summarized below. 


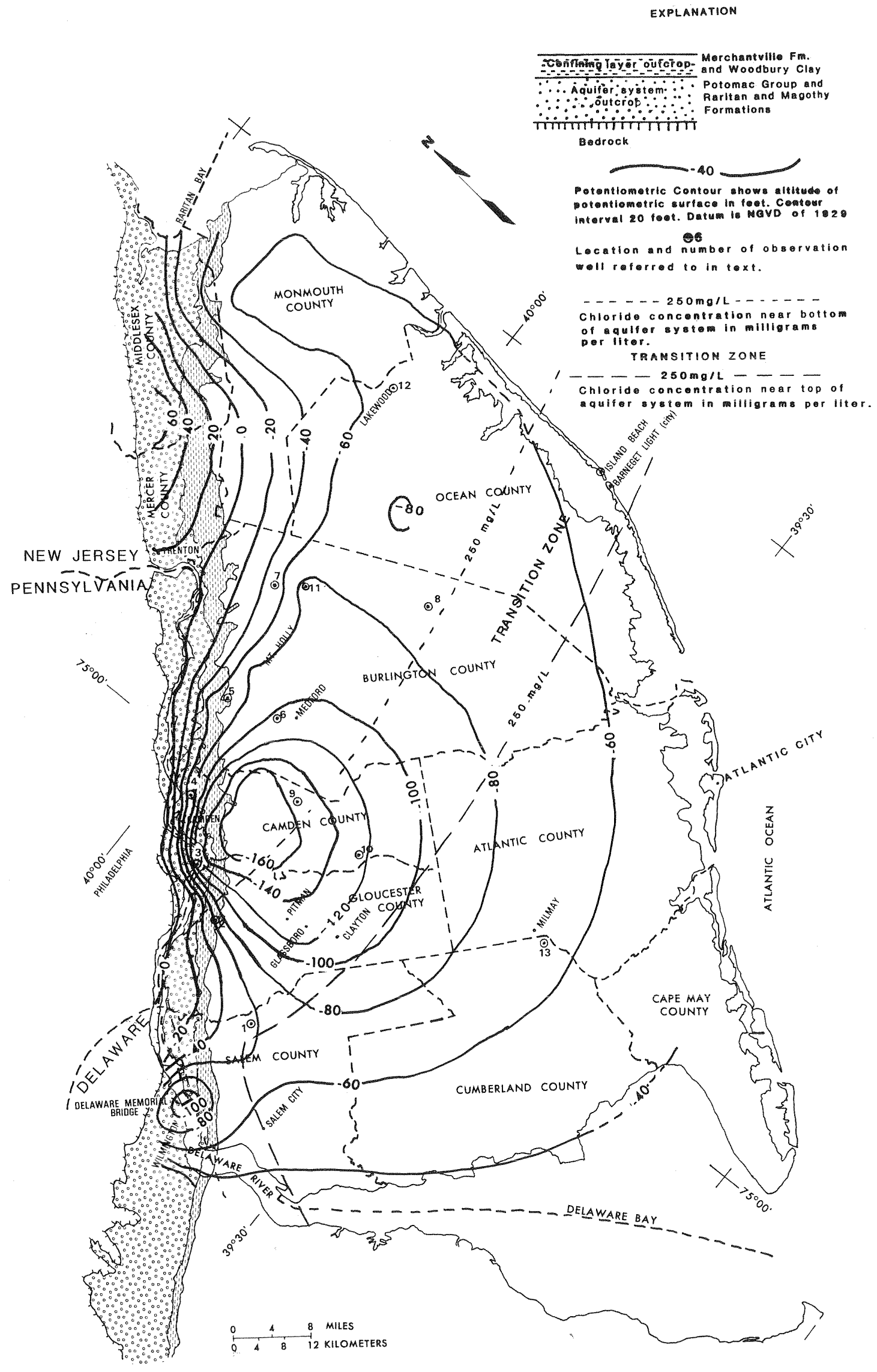

Figure 29.--Potentiometric surface of the Potomac-Raritan-Magothy squifer system computed by model with annul extraction growth rate of 3.0 percent. 


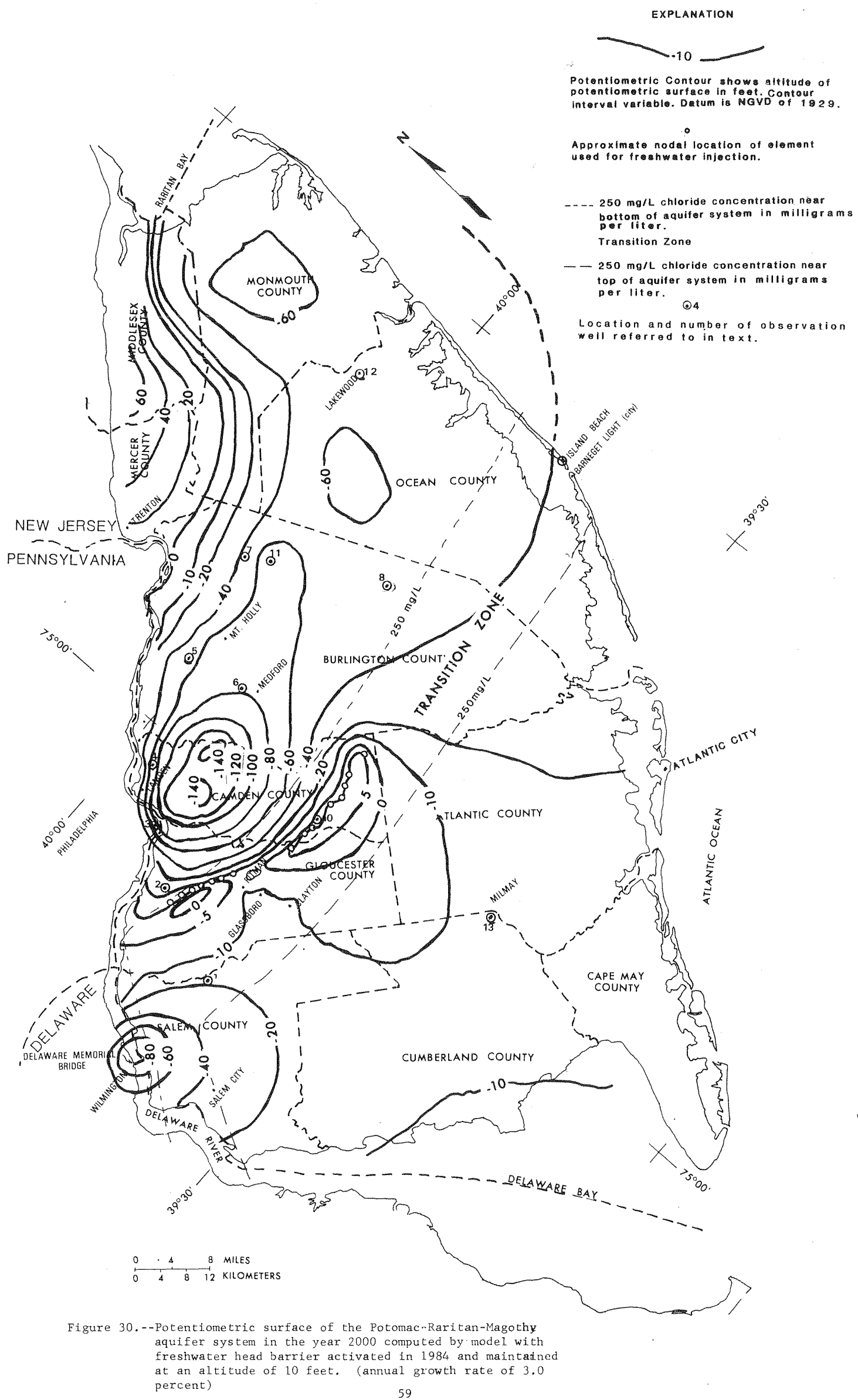


Recharge rates required

for freshwater barrier to

prevent saltwater migration

Percent of

extractions

Range/node Average/node

Total for

in fine-grid

Year

$\left(\rho t^{3} / s\right)$

$\left(f^{3} / s\right)$

19 nodes

area

$\left(f t^{3} / s\right)$

\begin{tabular}{lllll}
\hline 1984 & $1-5$ & 3 & 56 & 18 \\
1992 & $2-7$ & 4 & 78 & 20 \\
2000 & $2-8$ & 5 & 95 & 20 \\
\hline
\end{tabular}

The average recharge rates are feasible theoretically through one or more wells per node; however, it may be difficult to achieve or to maintain such recharge rates. In addition, by 1992, some nodes close to the center of the cone of depression near Pitman ( $\mathrm{fig}$. 30) might require recharge rates as high as $7 \mathrm{ft}^{3} / \mathrm{s}$. More than one well would be required in each of the 19 nodes to maintain a freshwater barrier under the assumptions used. In a real situation, many barrier wells would be used in the area represented by one node. Use of widely spaced wells would require that heads in the wells be maintained greater than $10 \mathrm{ft}$ in order to make the minimum head between wells $10 \mathrm{ft}$.

In order to maintain the head along the freshwater barrier at $10 \mathrm{ft}$ above NGVD of 1929, the projected 1984 potentiometric surface would have to be raised a minimum of about. 25 ft near the west end of the barrier and a maximum of about 90 ft near Pitman. A perspective view of the sequential head buildup along the barrier is shown in figure 31 for 1.3 days, 13 days, and 16 years (year 2000) after freshwater injection started. Except for the presence of the barrier, potentiometric surface at the year 2000 (fig. 31) is similar to the one shown in the lower view of figure 29. Figures 24, 25, 26, and 30 demonstrate the impact of the barrier on heads in the aquifer system.

Figures 24,25 , and 26 show the head increases at great distances from the barrier (well 1, $9 \mathrm{mi}$ from the barrier; well 6 and well 5, $14 \mathrm{mi}$; and well $7,23 \mathrm{mi})$. Well 4 shows the least head increase ( $4 \mathrm{ft}$ ) because it is located only $1 \mathrm{mi}$ from the Delaware River. Over large areas of the cone of depression north of the barrier (figs. 28 and 30) water levels are raised about 30 ft to $60 \mathrm{ft}$ as a result of the barrier. The barrier prevents the pumping stresses in the north from reaching the aquifer system to the south. Therefore, south of the barrier the aquifer system is simply recovering, mostly because of steady leakage accumulation and only in part because of recharge from the barrier. Some pumping centers exist on the south side of the barrier (fig. 12), 


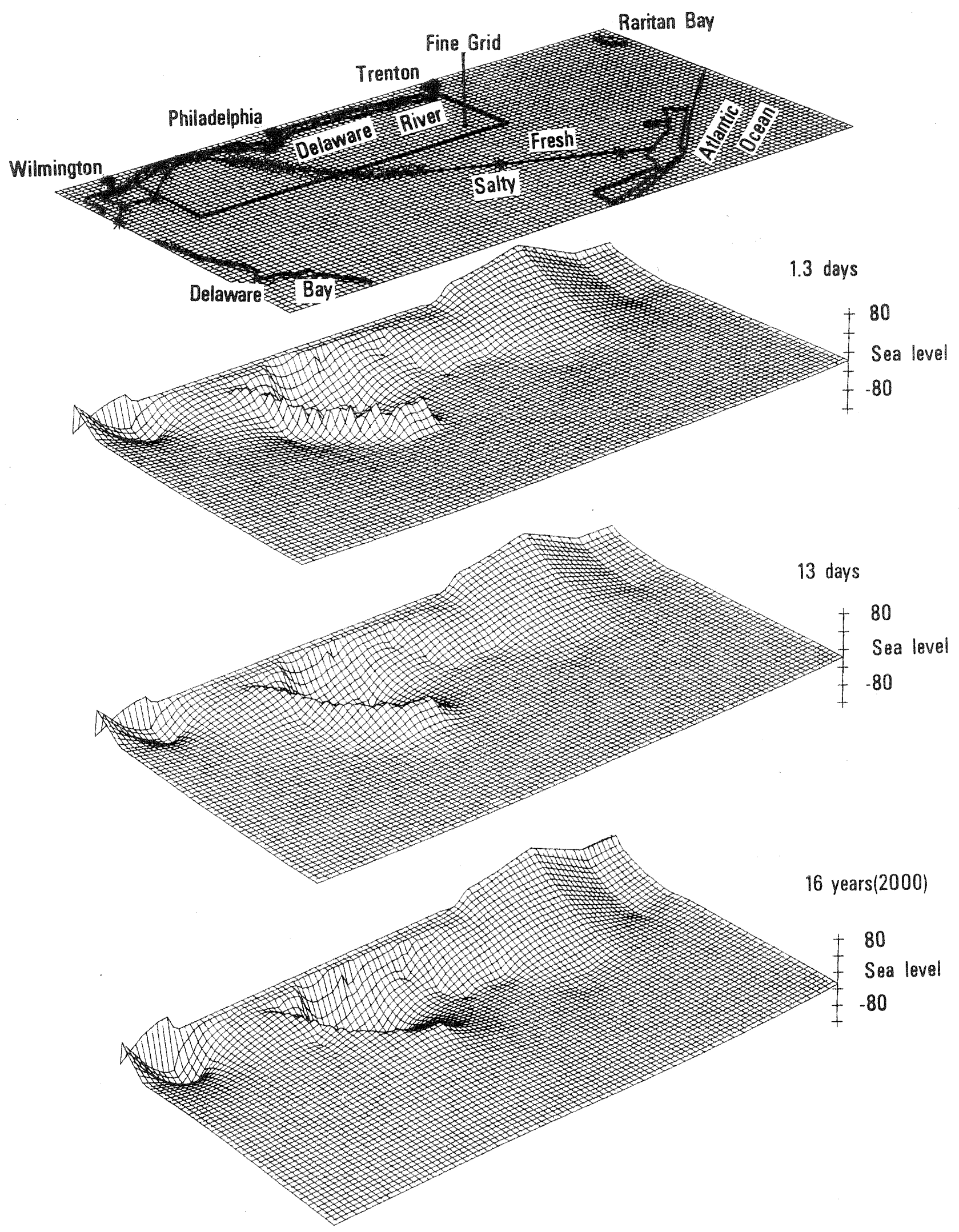

Figure 31.--Perspective potentiometric surfaces of the PotomacRaritan-Magothy aquifer system computed by model at various time periods after activation of freshwater head barrier in 1984 . 
but they are relatively small. In addition to preventing migration of the salty ground water, the freshwater head barrier acts as a significant source of recharge to the nearby pumping centers.

The upper Tertiary Cohansey Sand, a highly productive water-table aquifer exposed throughout the Pine Barrens of the Atlantic Coastal Plain of New Jersey (Barksdale and others, 1958, p. 155), could probably supply all the water needed to maintain the barrier. This can be achieved in part by gravity wells that are fully screened and gravel packed throughout the Cohansey Sand and. the Potomac-Raritan-Magothy aquifers. Feasibility study and economic considerations associated with such a barrier would have to be explored in a pilot operation.

GROUND-WATER VELOCITIES NEAR FRESH-SALTY WATER TRANSITION ZONE

According to Lohman (1972, p. 10), the average ground-water velocity may be computed by the following equation

where

$$
\bar{v}=-\frac{K d h / d l}{\theta}
$$

$$
\begin{aligned}
& \bar{v}=\text { average velocity in } \mathrm{ft} / \mathrm{d} \\
& \mathrm{K}=\text { hydraulic conductivity in } \mathrm{ft} / \mathrm{d} \\
& \text { (transmissivity divided by aquifer thickness) } \\
& \mathrm{dh} / \mathrm{dl}=\text { hydraulic gradient in ft/ft and } \\
& \theta=\text { porosity (dimensionless) }
\end{aligned}
$$

Because the water density varies within the fresh-salty water transition zone, the rate of movement of the transition zone cannot be calculated. However, the water density near the leading edge of the transition zone can be assumed to be close to the fresh ground water, and the rate of movement of the leading edge probably can be approximated by the calculation obtained from equation (4). The results are summarized in table 5.

$$
\text { MODEL-ESTIMATED GROUND-WATER BUDGETS }
$$

A mass balance was computed by the model for each simulation in order to check the numerical accuracy of the solutions. As part of that computation, each individual net flux component is itemized and tabulated to form a ground-water budget for the entire model and for the fine-grid area. Such a budget provides a measure of the relative importance of each flux component in the overall solution. Table 6 summarizes the ground-water budget rates within the fine-grid area computed by the model for the years from 1900 to 2000.

The computed ground-water budgets in the fine-grid area were plotted and shown in figure 32. In the projection period only the 
Table 5.--Estimated average ground-water velocities near the leading edge of the transition zone

\begin{tabular}{|c|c|c|c|c|c|}
\hline \multirow[b]{2}{*}{$\begin{array}{l}\text { Projected } \\
\text { extraction } \\
\text { growth } \\
\text { rate } \\
\text { (percent) }\end{array}$} & \multirow[b]{2}{*}{ Year } & \multicolumn{2}{|c|}{ Area north of Clayton 1/ } & \multicolumn{2}{|c|}{$\begin{array}{c}\text { Area between Delaware River } \\
\text { and well } 2 \text { 긔 }\end{array}$} \\
\hline & & $\begin{array}{l}\text { Hydraulic } \\
\text { gradient } \\
\text { (ft/mi) }\end{array}$ & $\begin{array}{l}\text { Average } \\
\text { ground-water } \\
\text { velocity } \\
\text { (ft/yr) }\end{array}$ & $\begin{array}{l}\text { Hydraulic } \\
\text { gradient } \\
\text { ( } \mathrm{ft} / \mathrm{mi})\end{array}$ & $\begin{array}{l}\text { Average } \\
\text { ground-water } \\
\text { velocity } \\
\text { (ft/yr) }\end{array}$ \\
\hline- & 1956 (meas.) & 0.8 & 12 & 0.6 & 35 \\
\hline- & 1973 (meas.) & 1.4 & 20 & 4.5 & 268 \\
\hline-- & 1973 (calc.) & 2.1 & 31 & 5.0 & 296 \\
\hline 1.7 & 2000 (calc.) & 3.8 & 55 & 7.1 & 422 \\
\hline 3.0 & $2000(\mathrm{calc})$. & 6.5 & 95 & 10.5 & 620 \\
\hline
\end{tabular}

1/ Velocities north of Clayton based on average sand thickness of $225 \mathrm{ft}$ ( 25 percent aquifer thickness), porosity of 25 percent, transmissivity of $12,000 \mathrm{ft}^{2} / \mathrm{d}$ and, gradients from contour maps presented in this report.

2/ Velocities between Delaware River and well 2 based on average sand thickness of $117 \mathrm{ft}$ ( 50 percent of aquifer system thickness, porosity of 25 percent, transmissivity of $25,000 \mathrm{ft}^{2} / \mathrm{d}$, and gradients from contour maps presented in this report. 
Table 6.--Computed ground-water budget net flux rates in cubic feet per second within the fine-grid area for various runs of the model

\begin{tabular}{|c|c|c|c|c|c|c|c|c|c|c|}
\hline $\begin{array}{l}\text { Run } \\
\text { No. }\end{array}$ & $\begin{array}{l}\text { Projected } \\
\text { extraction } \\
\text { growth rate } \\
\text { (percent } \\
\text { per year) }\end{array}$ & Year & Extractions & $\begin{array}{l}\text { River } \\
\text { sources** } \\
\text { (constant } \\
\text { head) }\end{array}$ & $\begin{array}{l}\text { Steady } \\
\text { leakage }\end{array}$ & $\begin{array}{l}\text { Precipitation } \\
\text { on outcrop }\end{array}$ & $\begin{array}{l}\text { Lateral } \\
\text { NE side }\end{array}$ & $\begin{array}{c}\text { inflow }(+) \text { or } \\
\text { SE side }\end{array}$ & $\begin{array}{l}\text { outflow }(-) \\
\text { SW side }\end{array}$ & $\begin{array}{l}\text { Aquifer } \\
\text { Storage }\end{array}$ \\
\hline 1 & -- & $1900 *$ & 0.0 & -69.5 & 14.7 & 38.6 & 13.2 & -0.4 & 2.8 & 0.0 \\
\hline 2 & -- & 1956 & -116.8 & 19.2 & 45.0 & 38.6 & 11.8 & $3 \cdot 3$ & -0.1 & 0.16 \\
\hline 3 & -- & 1961 & -149.0 & 40.6 & 52.6 & 38.6 & 13.0 & 5.2 & -0.9 & 0.25 \\
\hline 4 & -- & 1967 & -186.6 & 69.5 & 60.7 & 38.6 & 12.4 & 5.9 & -0.7 & 0.03 \\
\hline 5 & -- & 1973 & $-223 \cdot 5$ & 95.1 & 68.8 & 38.6 & 13.4 & 7.1 & -0.1 & 0.31 \\
\hline 6 & 0 & $2000 *$ & $-223 \cdot 5$ & 96.5 & 69.0 & 38.6 & $13 \cdot 3$ & 6.0 & -0.1 & 0.002 \\
\hline 7 & 1.7 & 2000 & -346.4 & 192.4 & 93.4 & 38.6 & $13 \cdot 3$ & $10 \cdot 3$ & -1.7 & 0.33 \\
\hline 8 & 3.0 & 2000 & -482.0 & 300.0 & 116.2 & 38.6 & $13 \cdot 5$ & 15.9 & $-3 \cdot 2$ & 1.50 \\
\hline 9 & 3.0 & $2000 * * *$ & -482.0 & 317.0 & 98.3 & 38.6 & 13.1 & 21.1 & -5.6 & 0.61 \\
\hline
\end{tabular}

* Steady-state solutions.

* Negative rate indicates flow from the aquifer system to river;

Positive rate indicates induced recharge from river (and minor outcrop reach near philadelphia)

to the aquifer system; for run no. 9 includes recharge from freshwater barrier injection nodes.

** Same as no. 8 but with freshwater barrier emplaced in 1984.

NOTE: Percentages in second column indicate compound annual extraction growth rates

for the period 1974-2000. 


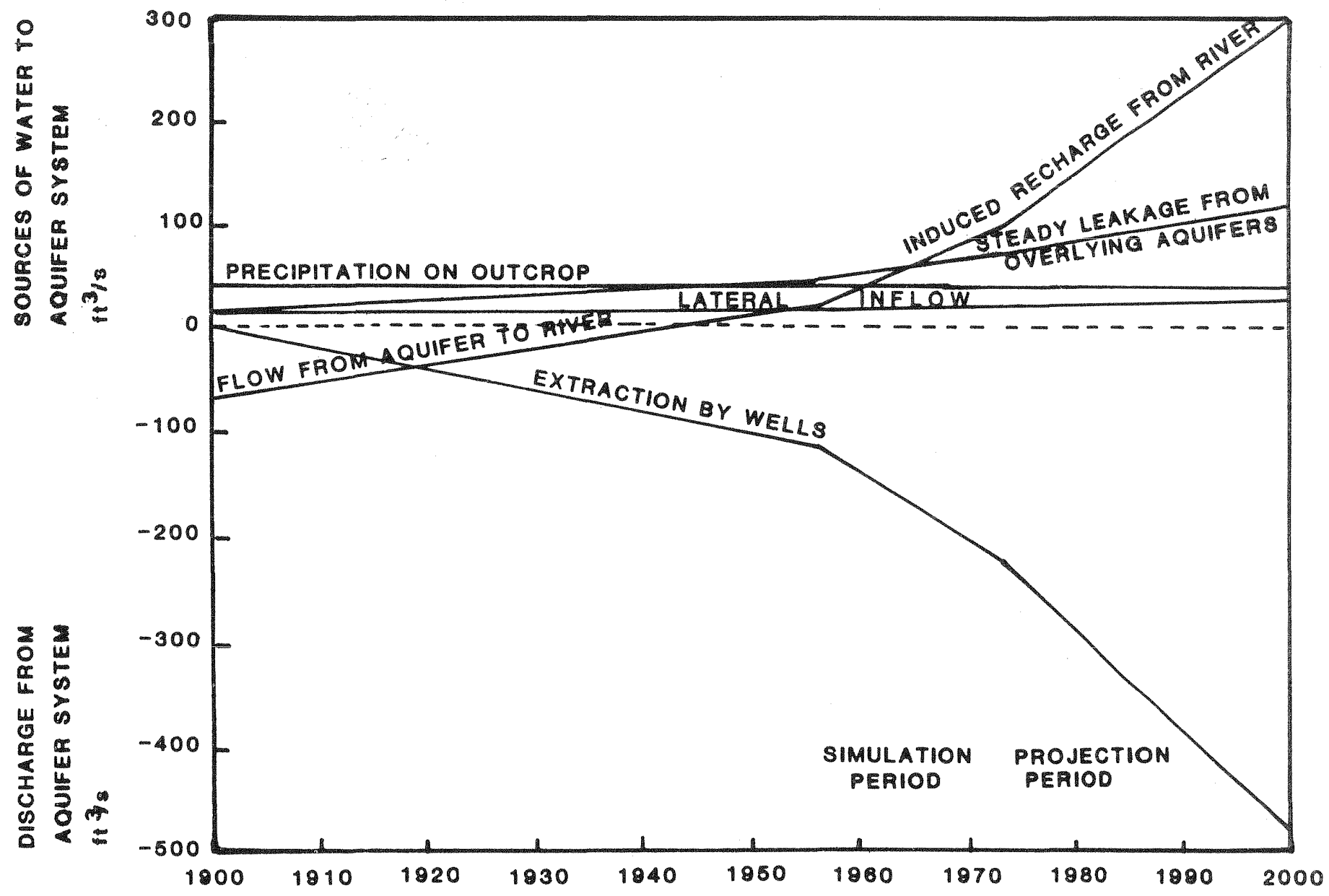

Figure 32.--Computed ground-water budget rates in the fine-grid area, $1900 \pm$ to the year 2000. (Budget rates after 1974 are plotted only for the 3.0 percent projection. Rates from storage are too small to show.) 
water budget related to the pumping growth rate of 3.0 percent per year was plotted. The amount of departure of the curves above and below the zero line represents the net exchange between recharge and discharge. The steady-state analysis for the year 1900 suggests that nearly all the water recharged to the aquifer system was being discharged into the Delaware River. However, a small amount of outflow through the southeastern boundary of the fine grid (table 6) was probably being discharged by upward leakage into overlying aquifers.

The computed budget suggests that under nonpumping conditions (1900) ground-water discharge from the aquifer system to the Delaware River in the fine-grid region amounted to about $70 \mathrm{ft}^{3} / \mathrm{s}$. For the entire model, the computed discharge is $112 \mathrm{ft}^{3} / \mathrm{s}$. These figures are approximately close to an estimate of a total discharge from aquifers of $77 \mathrm{ft}^{3} / \mathrm{s}$ made by Barksdale and others (1958, p. 129). Because the aquifer system was undeveloped and most of the outcrop was actually an area of discharge ( $\mathrm{figs} .11$ and 21), much of the precipitation (39 $\mathrm{ft}^{3} / \mathrm{s}$ ) would be discharged into streams. In the fine-grid area, steady leakage was $15 \mathrm{ft}^{3} / \mathrm{s}$ or 21 percent of the discharge to the Delaware River, while lateral inflow through boundaries was $16 \mathrm{ft}^{3} / \mathrm{s}$ or about 23 percent of the total discharge to the river. At sometime between 1943 and 1960 (fig. 32) net flow from the aquifer system to the river was gradually reduced. Thereafter, the growth in extraction rates caused a rapid increase in induced recharge from the Delaware River. The model simulation which used a projected pumping growth rate of 3 percent per year, which is similar to that experienced during the 18-year simulation period, suggests that by the year 2000 induced recharge from the Delaware River could account for approximately 62 percent of the total extractions; and the water from the steady leakage through the overlying aquifers accounts for 24 percent of extractions. These percentages compared with about 43 percent from induced recharge and about 31 percent from steady leakage for 1973, and 16 and 39 percent, respectively, for 1956. These figures indicate that more and more water will be induced from the Delaware River as extractions increase accordingly.

\section{SUGGESTIONS FOR FURTHER STUDY}

The presence of the large body of salty ground water in the aquifer system, in conjunction with the salty lower reaches of the Delaware River, represents the greatest threat to the contamination of the aquifer system. Sources of industrial pollution in the outcrop area are also potential threats for contamination of ground water in local areas. Continuation of head decline due to pumping, however, does not appear to be serious unless compaction and land subsidence become evidenced.

Since the Delaware River is an important source of induced recharge, the following suggestions are made: 
1. The model could be used to help determine whether the conjunctive use of ground water and surface water could minimize or prevent contamination of wells by salty water in the Delaware River during extreme low-flow periods. For example, steep hydraulic gradients from the river to the aquifer system cause large amounts of induced recharge. The gradients could be reduced or possibly even reversed by (a) a combination of injecting river water into existing production wells, or using river water directly as a source during periods of excess fresh flow (roughly December through May) and (b) by temporarily shutting down well fields close to the river during extreme low flow periods. This would shift pumping stress to wells further downdip. Conversely, during most years, optimal production of ground water from the aquifer system could be obtained by placing well fields as close as possible to freshwater reaches of the river. This would significantly lessen the impact of pumping stresses on the rest of the aquifer system and could reduce the rates of movement of salty ground water in the transition zone. The validity of using the model simulations for such water-management alternatives should be evaluated using monitoring data.

2. One or a series of pilot injection wells should be constructed and put into operation for several years to determine the feasibility and costs of a freshwater-head barrier in the transition zone.

3. Test drilling and water-quality sampling at different points in a vicinity of the transition zone near Clayton should be undertaken to determine the vertical and lateral variation in chloride concentration in an effort to assess needs and methods of monitoring the movernent of the salty ground-water body.

4. A comprehensive water-quality study should be undertaken within and near the transition zone and in the outcrop area from Mercer County to Salem County. This study should include sources of contamination, such as toxic waste disposal sites, and areas where poor quality river water has migrated into the aquifer system.

5. The head distribution throughout the aquifer system and overlying aquifers should be measured in March and April, about every 8 to 10 years, if rates of head decline continue at about 1.5 to $2.5 \mathrm{ft} / \mathrm{yr}$.

6. The model should be updated with new extraction data and additional data on head distribution and well hydrographs.

7. The model could be improved so that less restrictive assumptions are made. Transient leakage could be added to the existing model, and a new multilayer model could be made. 
A two-dimensional finite difference model was used to simulate the response of the Potomac-Raritan-Magothy aquifer system to pumping stresses during the 18-year period, 1956 through 1973. Acceptance of the model as a means of projecting head distribution in the aquifer system is based on a close correlation between the trends of observed and model computed water-level hydrographs for ten observation wells spaced throughout the area of Salem, Gloucester, Camden, and Burlington Counties; close correlation between observed and computed potentiometric surfaces at the end of the simulation period (1973); goodness of fit between the model-generated nonpumping steady-state potentiometric surface and the (1900t) surface determined by water-level observations; and model-generated hydrologic budgets that appear reasonable and supportable, both for the transient simulation and the steady-state solution.

Since 1900 extractions have gradually increased, reaching about $180 \mathrm{ft}^{3} / \mathrm{s}$ in 1956 to about $340 \mathrm{ft}^{3} / \mathrm{s}$ in 1973. Continuous and widespread reductions in head, averaging about 2 to $3 \mathrm{ft} / \mathrm{yr}$, have formed broad cones of depression with elevations well below sea level throughout most of the aquifer.

A large body of salty ground water, with chloride concentrations ranging from 250 to $27,000 \mathrm{mg} / \mathrm{L}$, occupies the aquifer system in the southern half of the coastal plain and connects with the aquifer's fresher water across a broad diffusion zone of 6 to $12 \mathrm{mi}$ in width. Head reductions caused by pumping have been more than sufficient to cause slow migration of the salty ground water towards pumping centers. The head reductions also induce large volumes of freshwater and some salty water into the aquifer system from the Delaware River estuary.

In general, the three stratigraphic units (Potomac Group, and the Raritan and Magothy Formations) that comprise the aquifer system appear to function together as a hydrologic system. Long-term records at clustered observation wells, some of which are quite remote from pumping centers, show rates of vertical head decline and suggest that much of the aquifer system responds rather uniformly to pumping stress.

Model results suggest that in 1900, the Delaware River estuary, which was a major discharge area for the aquifer system gained about $70 \mathrm{ft}^{3} / \mathrm{s}$ from the aquifer system in New Jersey between Trenton and the Delaware Memorial Bridge. Sometime in the period of 1943-60, due to increased ground-water extractions, ground-water discharge into the Delaware River was gradually reduced. Thereafter, increased extractions through 1973 caused induced recharge from the Delaware River estuary to approach 95 $\mathrm{ft}^{3} / \mathrm{s}$, which is about 43 percent of the $224 \mathrm{ft}^{3} / \mathrm{s}$ extracted in the principal interest area. Steady leakage from the overlying aquifers accounted for 31 percent of extractions while other 
sources accounted for 26 percent.

Model projections to the year 2000, using the 1973 well distribution, suggest that if extractions were kept constant (zero growth), further head reduction in the aquifer system would cease within two years over large parts of the study area. If extractions grew at a compounded annual rate of three percent, a cone of depression already encompassing most of the coastal plain would broaden and deepen with heads ranging from 60 to $160 \mathrm{ft}$

- below NGVD of 1929 by the year 2000. Steeper hydraulic gradients would increase the migration of salty ground water towards pumping centers. Induced recharge from the Delaware River estuary in the fine-grid area would increase to about $300 \mathrm{ft}^{3} / \mathrm{s}$ or 62 percent of the extractions in this area. A line of injection wells could be established to maintain a freshwater head barrier in the transition zone to prevent further migration of salty ground water across a 35-mi stretch in Gloucester, Camden, and Burlington Counties. Total rate of injection to the head barrier would range from about $56 \mathrm{ft}^{3} / \mathrm{s}$ in 1984 to about $95 \mathrm{ft}^{3} / \mathrm{s}$ in 2000. Barrier recharge rates would be equivalent to about 20 percent of the annual extractions in the fine-grid area for a pumping growth rate of 3 percent.

The results of this study generally confirm the following conclusion made by Barksdale and others (1958, p. 126).

"The great value of the ground-water supplies from the Raritan and Magothy formations justifies all reasonable measures to prevent or delay the serious and longlasting effects of saltwater encroachment. The maintenance of freshwater in the Delaware is probably the most important preventive measure that can be taken. Next in importance would be the careful and intelligent areal distribution of pumpage in such a way as to take maximum advantage of induced freshwater recharge and to avoid concentrated reductions of freshwater head near the margin of the saltwater in the aquifers." 
Anderson, H. R., and Appel, C. A., 1969, Geology and ground-water resources of Ocean County, New Jersey: New Jersey Department of Conservation and Economic Development Special Report 29, $93 \mathrm{p}$.

Barksdale, H. C., Greenman, D. W., Lang, S. M., Hilton, G. S., and Outlaw, D. E., 1958, Ground-water resources of the tri-state region adjacent to the lower Delaware River: New Jersey Department of Conservation and Economic Development Special Report 13, $190 \mathrm{p}$.

Barksdale, H. C., Johnson, M. E., Schaefer, E. J., Baker, R. C., and DeBuchananne, G. D., 1943, The ground-water supplies of Middlesex County, New Jersey: New Jersey State Water Policy Commission Special Report 8, $154 \mathrm{p}$.

Brown, P. M., Miller, J. A., and Swain, F. M., 1972, Structural and stratigraphic framework, and spatial distribution of permeability of the Atlantic Coastal Plain, North Carolina to New York: U.S. Geological Survey Professional Paper 796, $57 \mathrm{p}$.

Farlekas, G. M., Nemickas, Bronius, and Gill, H. E., 1976, Geology and ground-water resources of Camden County, New Jersey: U.S. Geological Survey Water Resources-Investigations 76-76, $146 \mathrm{p}$.

Gi11, H. E., and Farlekas, G. M., 1976, Geohydrologic maps of the Potomac-Raritan-Magothy aquifer system in the New Jersey Coastal Plain: U.S. Geological Survey Hydrologic Investigations Atlas HA-557.

Greenman, D. W., Rima, D. R., Lockwood, W. N., and Meisler, Harold, 1961, Ground-water resources of the coastal plain area of southeastern Pennsylvania: Pennsylvania Geological Survey Bulletin, 4th ser., W13, 375 p.

Hardt, W. F., and Hilton, G. S., 1969, Water resources and geology of Gloucester County, New Jersey: New Jersey Department of Conservation and Economic Development Special Report 30, $130 \mathrm{p}$.

Jablonski, L. A., 1968, Ground-water resources of Monmouth County, New Jersey: New Jersey Department of Conservation and Economic Development Special Report 23, $117 \mathrm{p} ., 27 \mathrm{figs.}$

Jacob, C. E., 1940, On the flow of water in an elastic artesian aquifer: American Geophysical Union Transactions, v. 21, p. $574-586$. 
Lohman, S. W., 1972, Ground-water hydraulics: U.S. Geological Survey Professional Paper $708,70 \mathrm{p}$.

Luzier, J.E., and Burt, R. J., 1974, Hydrology of basalt aquifers and depletion of ground water in east-central Washington: Washington Department of Ecology Water-Supply Bulletin 33, $53 \mathrm{p}$.

Luzier, J.E., and Skrivan, J. A., 1975, Digital-simulation and projection of water-level declines in basalt aquifers of the Odessa-Lind area, east central Washington: U.S. Geological Survey Water-Supply Paper 2036, 48 p.

Matalas, Nicholas C., and Maddock III, Thomas, 1976, Hydrologio Semantics: Water Resources Research, v. 12, no. 1, p. 123.

Nemickas, Bronius, 1976, Digital-simulation model of the WenonahMount Laurel aquifer in the coastal plain of New Jersey: U.S. Geological Survey Open-File Report 75-672, 42 .

New Jersey Department of Labor and Industry, 1975, New Jersey population projections 1980-2020: New Jersey Department of Labor and Industry, $6 \mathrm{p}$.

Nichols, W. D., 1977, Digital computer simulation model of the Englishtown aquifer in the northern Coastal Plain of New Jersey: U.S. Geological Survey Open-File Report 77-73, $101 \mathrm{p}$.

Owens, J. P., Minard, J. P., Sohl, N. F., and Mel1o, J. F., 1970, Stratigraphy of the outcropping post-Magothy Upper Cretaceous formations in southern New Jersey and northern Delmarva Peninsula, Delaware and Maryland: U.S. Geological Survey Professional Paper 674, 60 p.

Parker, G.G., Hely, A. G., Keighton, W. B., Olmsted, F. H., and others, 1964, Water resources of the Delaware River Basin: U.S. Geological Survey Professional Paper 381, 200 p.

Perry, W. J., Jr., Minard, J. P., Weed, E. G. A., Robbins, E. I., and Rhodehamel, E. C., 1975, Stratigraphy of Atlantic Coastal Margin of United States north of Cape Hatteras-brief survey: American Association of Petroleum Geologists Bulletin, v. 59, p. $1529-1548$.

Petters, S. W., 1976, Upper Cretaceous subsurface stratigraphy of Atlantic Coastal Plain of New Jersey: American Association of Petroleum Geologists Bulletin, v. 60, no. 1, p. 87-107.

Pinder, G. F., 1970, An iterative digital model for aquifer evaluation: U.S. Geological Survey Open-File Report, 44 p. 
Pinder, G. F., and Bredehoeft, J. D., 1968, Application of digital computer for aquifer evaluation: Water Resources Research, v. 4, no. 5, p. 1069-1093.

Powell, S. T., Consulting Engineers, Baltimore, Maryland, and Leggette and Brashears, Consulting Ground-Water Geologists, New York, 1954, Report on the effect of ship channel enlargement above Philadelphia: Report prepared for The Committee for Study of the Delaware River, Appendix A2-1.

Price, W. G., Jr., 1976, PURVUE: A program to plot perspective views of surfaces: Princeton University, Plasma Physics Laboratory report PPPL-1304, $14 \mathrm{p}$.

Rooney, J.G., 1971, Ground-water resources Cumberland County, New Jersey: New Jersey Department of Environmental Protection Special Report 34, 65 p.

Rosenau, J. C., Lang, S. M., Hilton, G. S., and Rooney, J. G., 1969, Geology and ground-water resources of Salem County, New Jersey: New Jersey Department of Conservation and Economic Development Special Report 33, $142 \mathrm{p}$.

Rush, F. E., 1968, Geology and ground-water resources of Burlington County, New Jersey: New Jersey Department of Conservation and Economic Development Special Report 26, $65 \mathrm{p}$.

Schlee, John, Behrendt, J. C., Grow, J. A., Robb, J. M., Mattick, R. E., Taylor, P. T., and Lawson, B. J., 1976, Regional geologic framework of Northeastern United States: American Association of Petroleum Geologists Bulletin, v. 60, no. 6 , p. $926-951$.

Sheridan, R. E., and Knebel, H. J., 1976, Evidence of Post-Pleistocene faults on New Jersey Atlantic Outer Continental Shelf: American Association of Petroleum Geologists Bulletin, v. 60, no. 7, p. 1112-1117.

Sundstrom, R. W., and Pickett, T. E., 1971, The availability of ground-water in New Castle County, Delaware: University of Delaware, Water Resources Center, 156 p.

Trescott, P. C., Pinder, G. F., and Larson, S. P., 1976, Finitedifference model for aquifer simulation in two dimensions with results of numerical experiments: Techniques of Water-Resources Investigations, Book 7, Chapter C1, $116 \mathrm{p}$.

Vecchioli, John, and Palmer, N. N., 1962, Ground-water resources of Mercer County, New Jersey: New Jersey Department of Conservation and Economic Development Special Report 19, $17 \mathrm{p}$. 